University of Baltimore Law ScholarWorks@University of Baltimore School of Law

1993

\title{
Televised Executions and the Constitution: Recognizing a First Amendment Right of Access to State Executions
}

John Bessler

University of Baltimore School of Law, jbessler@ubalt.edu

Follow this and additional works at: http://scholarworks.law.ubalt.edu/all_fac

Part of the Constitutional Law Commons, and the Law Enforcement and Corrections Commons

\section{Recommended Citation}

Televised Executions and the Constitution: Recognizing a First Amendment Right of Access to State Executions, 45 Fed. Comm. L.J. 355 (1993)

This Article is brought to you for free and open access by the Faculty Scholarship at ScholarWorks@University of Baltimore School of Law. It has been accepted for inclusion in All Faculty Scholarship by an authorized administrator of ScholarWorks@University of Baltimore School of Law. For more information, please contact snolan@ubalt.edu. 


\section{FEDERAL

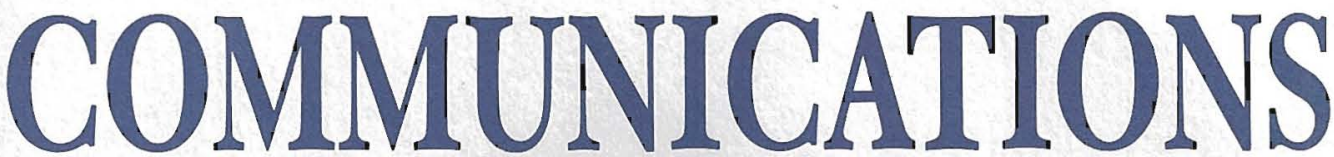 \\ LAW

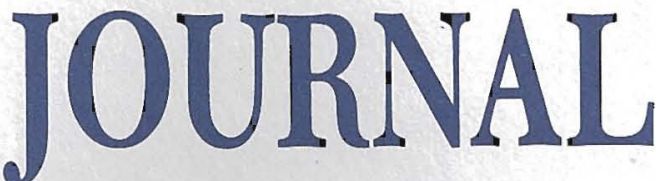

\section{ARTICLES}

TELEVISED EXECUTIONS AND THE

CONSTITUTION: RECOGNIZING A FIRST

AMENDMENT RIGHT OF ACCESS TO

STATE EXECUTIONS

John D. Bessler

INCONSISTENCIES IN APPLICATIONS OF

ECONOMICS AT THE FEDERAL

COMMUNICATIONS COMMISSION

Warren G. Lavey

Meeting the Challenges of Change:

THE REFORM OF THE INTERNATIONAL

TELECOMMUNICATION UNION

Audrey L. Allison

ESSAY

TOWARD A COMPROMISE ON COLlATERALIZING

LOANS TO BROADCASTERS

David Isenberg

\& Michael Reisz

\section{COMMENT}

Municipally-OWNed CABLE Television:

Why Cable Operators Should NoT

Choose the ChanNels

Scott A. Bearby

BOOK REVIEW

TELECOMMUNICATIONS IN EURop̣E

By ELI NOAM

John Davidson Thomas

Volume 45

August 1993

Number 3

Published by:

UCLA School of Law and the

Federal Communications Bar Association 


\title{
Televised Executions and the Constitution: Recognizing a First Amendment Right of Access to State Executions
}

\author{
John D. Bessler*
}

I. INTRODUCTION ............................. 356

II. History of Public Executions .............. 359

III. Current Statutory Schemes............... 368

IV. Challenges to Private Execution

STAtUTES ................................. 373

A. Federal Challenges ...................... 373

B. State Challenges...................... 382

V. Freedom of The Press Jurisprudence ....... 383

A. Access to Trials ......................... 383

B. Cameras in the Courtroom .................. 386

C. Prison Access .......................... 388

VI. The USE OF History IN CONSTITUTIONAL

ANALYSIS............................... 393

A. Death Penalty Cases..................... 393

B. Right of Access Cases...................... 394

1. Trials ............................ 394

2. Cameras in the Courtroom .............. 395

3. Prisons............................. 396

VII. Constitutionality of Televised

EXECUTIONS............................... 397

A. First Amendment Analysis ................ 398

1. Prior Restraint ....................... 398

2. Content Regulation ................. 400

* Associate, Faegre \& Benson, Minneapolis, Minnesota, 1991 - present; J.D. 1991, Indiana University School of Law at Bloomington; B.A. 1988, University of Minnesota at Minneapolis. 
3. Right of Access ..................... 409

B. Equal Protection Analysis................. 413

C. Right of Privacy Analysis ................. 414

VIII. INTEGRATING THE FIRST AMENDMENT WITH

TROP V. DULLES ......................... 418

A. "Evolving Standards of Decency" and "Human Dignity" ............................. 419

B. Implications for Private Execution Statutes .... 421

IX. Conclusion $\ldots \ldots \ldots \ldots \ldots \ldots \ldots \ldots \ldots \ldots \ldots, 432$

\section{INTRODUCTION}

The concept of televised executions occupies an odd position in the debate surrounding capital punishment. For, within the debate concerning the pros and cons of the death penalty itself, both proponents and opponents of capital punishment have argued for televised executions. While those favoring televised executions hope to realize their potential deterrent value ${ }^{1}$

1. In the last decade, several studies have been conducted regarding the effect of well-publicized executions. Compare David P. Phillips, The Deterrent Effect of Capital Punishment: New Evidence on an Old Controversy, 86 AM. J. Soc. 139 (1980) (a study concluding that the homicide rate drops after a well-publicized execution) and Steven Stack, Publicized Executions and Homicide, 1950-1980, 52 AM. SoC. REV. 532 (1987) ("On the average, a publicized execution story is associated with a drop of 30 homicides in the month of the story.") and Steven Stack, Execution Publicity and Homicide in South Carolina: A Research Note, 31 SocIologiCAL QuARTERLY 599 (1990) (homicide rate drops $17.5 \%$ in months with publicized executions) with William C. Bailey \& Ruth D. Peterson, Murder and Capital Punishment: A Monthly Time-Series Analysis of Execution Publicity, 54 AM. SoC. REV. 722 (1989) (criticizing the Stack study). For additional discussion of Phillips' study, see Wayne Kobbervig, James Inverarity \& Pat Lauderdale, Deterrence and the Death Penalty: $A$ Comment on Phillips, 88 AM. J. Soc. 161 (1982); Hans Zeisel, Comment on the Deterrent Effect of Capital Punishment, 88 AM. J. Soc. 167 (1982) (critique of the Phillips study); David P. Phillips, The Fluctuation of Homicide After Publicized Executions: Reply to Kobbervig, Inverarity, and Lauderdale, 88 AM. J. Soc. 165 (1982); David P. Phillips, Deterrence and the Death Penalty: A Reply to Zeisel, 88 AM. J. Soc. 170 (1982). See also William C. Bailey, Murder, Capital Punishment, and Television: Execution Publicity and Homicide Rates, 55 AM. Soc. Rev. 628 (1990); Robert B. Cialdini, InfluENCE: SCIENCE AND PRACTICE 141-43 (2d ed. 1988) (studies suggest an increase in the rate of crime and violence following the broadcast of violent television shows or movies); William C. Bailey \& Ruth D. Peterson, Capital Punishment and Non-Capital Crimes: A Test of Deterrence, General Prevention, and System-Overload Arguments, 54 ALB. L. REV. 681, 682 (1990) ("the analysis shows a significant inverse relationship between the amount and type of television coverage devoted to executions and the tates of assault, robbery and burglary"); David R. King, The Brutalization Effect: Execution Publicity and the Incidence of Homicide in South Carolina, 57 Soc. FORCES 683 (1978). 
or to provide broadcast news coverage of a significant public event, ${ }^{2}$ those opposed to televised executions are worried that such events will only "increase savagery" or "further coarsen our society."3 Moreover, although some commentators are not alarmed by the "executions-are-too-gruesome-for-TV" argument, ${ }^{4}$ some death penalty opponents hope that "the spectacle will so disgust the public that it will turn against capital punishment."s

Against this backdrop of public debate, several lawsuits challenging the constitutionality of laws which prohibit the filming of executions have been filed. ${ }^{6}$ Among other things, these challenges-brought by either death row inmates or journalists-have been based on the ground that the laws infringe upon the First Amendment rights of the press. Although the United States Supreme Court stated in dicta in 1890 that states may restrict the attendance of reporters at executions, ${ }^{7}$ the Supreme

2. Michael Schwartz, T.V. in the Death Chamber: A News Story Like Any Other, N.Y. TIMES, May 17, 1991, at A30 ("[T]elevision, used responsibly, can inform and elevate public awareness and discussion of the most important issues facing our society."). But see Jonathan Sherman, Pictures At an Execution, N.Y. TIMES, May 3, 1991, at A31 ("The marginal informational benefit of televised executions . . . would be small.").

3. Howard Rosenberg, TV: $A$ Witness for the Execution, L.A. TIMES, May 19, 1990, at F1 (quoting University of California, Berkeley professor and media critic Ben Bagdikian) (" 'increase savagery" "); George F. Will, Capital Punishment and Public Theater, WASH. Post, May 12, 1991, at C7 ("[s]olemnity should surround any person's death, and televised deaths might further coarsen American life"); Anthony Lewis, Their Brutal Mirth, N.Y. TIMEs, May 20, 1991, at A15 ("[Television] will trivialize executions-reduce them to the level of entertainment, to be clicked on and off."); see also Thomas Sowell, Televised Executions? Media Bias at 11, DETROrT News, July 22, 1991, at 10A ("The public has no more desire to see executions than to see abdominal surgery.").

4. Rosenberg, supra note 3, at F1.

5. Let TV Cameras Show Executions, USA TODAY, July 18, 1990, at 6A (opinion); Robert A. Harper, Jr., Seeing Death: Should Executions Be Public?, NEw JERSEY L.J., April 12, 1990, at 9; Anna Quindlen, TV Executions Will Force Us to Look Death in the Eye, CHI. TriB., May 21, 1991, Perspective Section, at 19. Compare Thomas Sowell, supra note 3, at 10A ("No doubt the whole point of televising executions is to present a spectacle that will disgust the viewers and therefore undermine public support for capital punishment, which the political left has long opposed.") with David Wilkes, Televised Coverage Would End Executions, N.Y. TIMES, May 30, 1991, at A24 ("Televised coverage would serve as proof to those who are ambivalent about the death penalty that state-sponsored executions should be relegated to the past.").

6. See infra Sections III and IV.

7. See Holden v. Minnesota, 137 U.S. 483 (1890). 
Court has never squarely addressed the question of whether bans on televised executions are constitutionally permissible.

In addressing this question, this Article considers the relationship between private execution laws and two groups - the press and the general public. Part II of this Article discusses the history of public executions, paying particular attention to the United States. Part III examines the existing statutory schemes of states which prohibit public executions. Part IV discusses cases which have challenged private execution schemes, and Part V explores freedom of the press jurisprudence. The use of history in constitutional analysis is the focus of Part VI, while Part VII analyzes the constitutionality of private execution statutes under various theories of constitutional analysis. Finally, Part VIII integrates First Amendment jurisprudence with the "evolving standards of decency" of Trop v. Dulles. ${ }^{8}$

This Article concludes that under existing authority private execution statutes are unconstitutional. In reaching this conclusion, this Article first establishes that private execution laws were originally enacted for paternalistic reasons and in response to a powerful movement in the 1830 s to abolish capital punishment. Tracing freedom of the press jurisprudence and the use of history in the context of other cases involving constitutional interpretation, this Article then takes the position that the long tradition of public executions in the United States and elsewhere gives the public a constitutional right to view executions. In particular, this Article argues that an historical approach, when coupled with the complete lack of governmental interests supporting modern private execution statutes, renders such laws unconstitutional because they impermissibly regulate the content of speech. Furthermore, although First Amendment principles generally give the press no greater right of access to events than the general public, this Article asserts that because the public has historically been allowed to witness executions, the press must be given effective access to such events. Because television is the most effective and influential medium of public information in the United States, this Article maintains that the press must be allowed to televise executions.

Finally, this Article asserts that the public has a right to

8. 356 U.S. 86,101 (1958). 
view executions based upon the Eighth Amendment principle that punishments not violate the "evolving standards of decency that mark the progress of a maturing society." In particular, this Article contends that televised executions are necessary for the Supreme Court to obtain an accurate measurement of society's evolving standards with respect to capital punishment. That is, because the Supreme Court uses elected representatives as the primary "objective indicia" of which punishments are "cruel and unusual," the general public-who elect public officials or who authorize the death penalty via referendums-must be allowed to view executions in order to be fully informed on the subject of capital punishment. Ultimately, this Article concludes that the general public must be allowed to view executions in order for the Supreme Court to accurately determine whether capital punishment is a "cruel and unusual punishment" under the Eighth Amendment.

\section{History of Public Executions}

Until the nineteenth century, executions in the United States were held in public," often in the "public squares or commons." ${ }^{10}$ Following a well-established tradition of public executions in England, ${ }^{11}$ capital punishment in the American colonies was administered before large crowds. ${ }^{12}$ According to one account, at the last public hanging in Philadelphia, which took place on May 19, 1837, an estimated crowd of 20,000 people witnessed the execution of nineteen-year-old James Moran. ${ }^{13}$ At such events, religious and community leaders appeared in a pub-

9. G. Mark Mamantov, Note, The Executioner's Song: Is There a Right to Listen?, 69 VA. L. REv. 373, 375 (1983). The Massachusetts Bay Colony capital statutes of 1641 were the first capital punishment laws in this country. THE DEATH PENALTY IN AMERICA 7 (Hugo A. Bedau ed., 3d ed. 1982).

10. LoUIS P. MASUR, RITES OF EXECUTION 59 (1989).

11. David D. Cooper, The Lesson of the Scaffold: The Public ExecuTION CONTROVERSY IN VICTORIAN ENGLAND 1-27 (1974). Indeed, community involvement in executions has been traced back as early as 3000 B.C., when stonings and executions were undoubtedly quite common. ROBERT JOHNSON, DEATH WORK 4, 6 (1990); see also John Laurence, A History of Capital Punishment (1960) (tracing the history of capital punishment).

12. See Negley K. Teeters \& JACK H. Hedblom, HaNG By THE NeCK 19-46, $59-63$ (1967).

13. Id. at 34. Although Pennsylvania abolished public hangings in 1834 , the victim had committed a federal offense-piracy-and was therefore not subject to the Pennsylvania law. Id. 
lic ceremony to display their authority and convey their messages to the crowd. ${ }^{14}$ While the overarching civil theme of execution day was the preservation of order, the primary spiritual message delivered concerned the consequences of crime and sin. ${ }^{15}$ Printed versions of the sermons and confessions helped disseminate the execution day message throughout the crowd and across the region. ${ }^{16}$

During the 1830 s, however, in response to a growing movement to abolish capital punishment, several states began to prohibit public executions. ${ }^{17}$ In New York, in 1834, for example, an assemblyman, Carlos Emmons, introduced a bill to abolish public executions. Initially, his idea met with bitter resistance from two groups. ${ }^{18}$ One faction, viewing public executions positively, felt that the practice should be continued. ${ }^{19}$ The other group, comprised of legislators who favored abolition of capital punishment altogether, rejected Emmons' proposal on Machiavellian

14. MASUR, supra note 10 , at 26.

15. Id. at 26-27.

16. Id. at 26.

17. See Davis, The Movement to Abolish Capital Punishment in America, 17871861, 63 AM. HIST. REv. 23, 33-34 (1957). According to one scholar, "[t] he move to exclude the public from executions was apparently motivated by a desire to make executions more civilized and by a fear that well-publicized executions would fan sentiment to abolish capital punishment altogether." Mamantov, supra note 9, at 375 (footnote omitted). The movement to abolish capital punishment in the United States began in 1787 under the direction of Dr. Benjamin Rush. The DeATH Penalty IN AMERICA, supra note 9, at 13.

Notably, Justice Marshall suggested that both the Civil War and the privatization of executions may have halted much of the furor to abolish capital punishment: "But the Civil War halted much of the abolition furor. One historian has said that '[a]fter the Civil War, men's finer sensibilities, which had once been revolted by the execution of a fellow being, seemed hardened and blunted.' " Furman v. Georgia, 408 U.S. 238, 338-39 (Marshall, J., concurring) (quoting Davis, The Movement to Abolish Capital Punishment in America, 1787-1861, 63 AM. HIST. Rev. 23, 46 n.64 (1957)). Marshall went on to state: "[E]xecutions, which had once been frequent public spectacles, became infrequent private affairs. The manner of inflicting death changed, and the horrors of the punishment were, therefore, somewhat diminished in the minds of the general public." Furman, 408 U.S. at 340 (Marshall, J., concurring) (footnote omitted).

18. Philip E. Mackey, hanging in the Balance: The Anti-Capital PunISHMENT MOVEMENT IN NEW YORK STATE, 1776-1861, at 115-16 (1982). The avowed purpose of Emmons' bill was to stop "the vicious assemblages and demoralizing tendencies of public executions." Id. at 116 (footnote omitted).

19. Id. at 117. "At least two assemblymen thought that the public would not be satisfied with private executions because they could not be sure that the hangings were actually being carried out." Id. 
grounds. Assemblyman Samuel Bowne told the Assembly that if executions were to exist at all, he wanted them to be public so "that their consequences and enormity might be more vividly impressed on the public mind."20 According to Bowne, the disgust produced by public executions would lead "to the entire abolition of capital punishment."21 Bowne's colleague, Amasa Parker, concurred; he would vote against Emmons' bill because "public executions would be ultimately instrumental in abolishing capital punishments."22

Although in 1834 Emmons' proposal was destined for failure, ${ }^{23}$ in 1835 a senate select committee of the New York legislature was directed to inquire "into the propriety of abolishing public executions." The committee recommended that newspapers be used to disseminate information about executions. Although very few people could obtain "ocular evidence" of a private execution, the legislators reasoned that newspaper accounts of an execution attested to by "respectable citizens who would attend the execution not as private spectators but as public witnesses" would protect against any "evasion, perversion, or abuse."24 According to the New York committee report: "[P]ublic executions ... . are of a positively injurious and demoralizing tendency."25 Using phrenological principles, ${ }^{26}$ the report mused whether those who attended executions were "of that

20. Id.

21. Id.

22. $I d$.

23. Emmons' bill failed to reach a final reading. Id.

24. MASUR, supra note 10, at 115 (quoting Senate Document No. 79 in Documents of the Senate of the State of New York, Fifty-Eighth Session, 1835 4, 10 (1835) [hereinafter Senate Report]).

25. Id. at 116.

26. By the time states began to abolish public executions, many Americans believed in phrenology, a psychological theory developed by two Austrian physicians, Johann Spurzheim and Franz Joseph Gall. Popularized in America by George Combe, phrenology analyzed behavior "by viewing the brain as the mind's organ." George Combe, who himself connected capital punishment with phrenology, stated that the effect of witnessing an execution depended upon one's constitution. Arguing that public executions would effectively deter only "all favorably constituted men," Combe reasoned that public executions would "operate with least effect precisely on those on whom it is most needed, viz., on such as by nature and circumstance are most prone to fall before temptation." MASUR, supra note 10, at 98. Horace Mann, a legislator from Massachusetts who first proposed the abolition of public executions in that state, was so devoted to phrenology that he named a son after George Combe. Id. at 100; see also id. ("In the 1830s phrenology provided a compelling argument against 
class of citizens whose reason is to be convinced, or whose animal feelings are to be excited."27 A month after the report, the New York legislature adopted a private execution statute which took effect on May 9, 1835. ${ }^{28}$

The private execution statutes enacted in the various state legislatures generally provided for a limited number of witnesses at executions and required the sheriff to provide an enclosure for the event. ${ }^{29}$ For instance, in Pennsylvania, where a private execution statute was enacted in 1834, the law required that an execution take place "within the walls or yard of the jail."30 Under the Pennsylvania law, the sheriff had the discretion to select the witnesses, providing that at least one physician, the attorney general, and "twelve reputable citizens" be invited. In addition, the law expressly prohibited minors from attending an execution. ${ }^{31}$

In general, states in New England were the first to enact private execution laws, and states in the South and Midwest

public hangings at a time when social authorities increasingly feared a crisis of public order.").

27. Id. at 116 .

28. MaCKey, supra note 18, at 118. As Philip Mackey's historical study of New York concluded:

The abolition of public hangings both hurt and helped the campaign to abolish all capital punishment. Just as Samuel Bowne and Amasa Parker had feared, the removal of hangings from the public view almost certainly relieved the current pressure for total abolition. It decreased the supply of new reformers by ending the recurrent scenes which had turned so many against the death penalty. It also gave current reformers the impression that the government had met them half way. These results were at least partially responsible for the absence of anti-gallows activity during the 1836 and 1837 legislative sessions and the slow progress of the reform even later. On the other hand, reformers after 1835 could claim that the abolition of public hanging proved that the champions of the gallows were wrong and knew it. As a proponent of the death penalty put it in 1848, the end of public execution "forced the suggestion that capital punishment was barbarous."

Id. at 119 (citation omitted).

29. Mamantov, supra note 9, at 375. One author has noted that private executions "became a theatrical event for an assembly of elite men who attended the execution by invitation while the community at large was excluded." Masur, supra note 10, at 111 (citing several examples); $i d$. at 112 ("Lucy Colman, anti-slavery lecturer and women's rights activist, reported ... that at the execution of Ira Stout 'not one of my sex was invited." ").

30. Pub. Act No. 127, 1833-34 Pa. Laws 234-235.

31. Id.; see also Journal of the Forty-fifth House of Representatives (Harrisburg, 1834), at 446-47; Report on the Expediency of Abolishing Public Executions (Harrisburg: Henry Welsh, 1833), at 4 . 
soon followed. ${ }^{32}$ However, because of lax enforcement and the lack of proper facilities to provide private executions, private execution laws did not completely eliminate public access to executions. The end of public executions was not assured until state governments took control of executions from the county sheriffs. Although Maine, Michigan, and Vermont enacted such legislation in the 1840s, the majority of state legislatures did not assume control over executions until the early part of this century. ${ }^{33}$

Four states, unsatisfied that even state-controlled executions would curtail public executions, imposed criminal penalties for the publication of the details of an execution. ${ }^{34}$ Minnesota's private execution statute, enacted in 1889, was typical of such statutes. According to the Minnesota law:

The warrant of execution shall be executed before the hour of sunrise of the day designated in the wariant and within the walls of the jail in all cases where the jail is so constructed that it can be conveniently done therein; but when the jail is not so constructed, the warrant shall be executed within an enclosure which shall be higher than the gallows, and shall exclude the view of persons outside, and which shall be prepared for that purpose .... 35

The statute also provided for witnesses to attend the execution. The sheriff of the county was to be present, along with any assistants the sheriff deemed necessary. ${ }^{36}$ Besides the sheriff and his assistants, the following persons, but no others, were to be present at the execution: a clergyman or priest, a physician or surgeon, up to three persons designated by the prisoner, and up to six other persons designated by the sheriff. ${ }^{37}$ Although the statute left witness selection at the discretion of the prisoner and

32. Mamantov, supra note 9 , at $375 \& \mathrm{nn} .19-20$ (citing laws).

33. Id. at $377 \&$ nn.26-28 (citing laws). Northeastern states were generally the first to adopt state-controlled execution laws. The other state legislatures adopted such measures as early as 1885 , in the case of Ohio, and as late as 1956, in the case of Louisiana. To date, only the states of Delaware and Montana do not require that executions be under state control. Id. at 377 n.28 (citing laws and WILLIAM J. BOWERS, EXECUTIONS IN AMERICA 11 (1974)).

34. Act of Feb. 15, 1913, Pub. L. No. 55, § 10, 1913 Ark. Acts 171, 174; Act of Apr. 19, 1889, §§ 3, 6, 1889 Colo. Sess. Laws 118, 119-20; Act of Apr. 24, 1889, ch. $20, \S \S 5,6,1889$ Minn. Laws 66, 67; Act of Mar. 16, 1908, ch. 398, $\S 10,1908 \mathrm{Va}$. Acts 684, 686 .

35. 1889 Minn. Laws, ch. $20, \S 3$.

36. Id. at $\S 2$.

37. Id. 
the sheriff, the statute explicitly provided that "no person so admitted shall be a newspaper reporter or representative." 38 Furthermore, Minnesota's statute provided that "[n]o account of the details of such execution, beyond the statement of the fact that such convict was on the day in question duly executed according to law, shall be published in any newspaper." ${ }^{39}$ Any violation of Minnesota's private execution statute was punishable as a misdemeanor. ${ }^{40}$

Indeed, in 1906, an indictment was obtained against three newspapers for publishing the details of what later proved to be the last hanging in Minnesota. In that case, the three newspapers-including The St. Paul Pioneer Press - all published details of the hanging of William Williams, convicted of killing a 16-year-old boy and his mother. The strangulation of Williams, which took fourteen-and-a-half minutes to complete because the hangman failed to consider that both rope and the condemned's neck stretches, ${ }^{41}$ ignited a movement in Minnesota to abolish capital punishment, which ultimately succeeded in $1911 . .^{42}$

In the ensuing court case, State v. Pioneer Press $\mathrm{Co}_{0},^{43}$ the Pioneer Press was fined twenty-five dollars. ${ }^{44}$ More significantly, however, Minnesota's private execution statute was held constitutional by the Minnesota Supreme Court. According to the court:

The evident purpose of the act was to surround the execution of

38. Id. at $\S 5$.

39. Id. at $\S 5$.

40. Id. at $\S 6$. Minnesota's private execution statute was known as the John Day Smith law in recognition of the legislator who originally sponsored the bill. A legislator from Minneapolis, Smith once tried-albeit unsuccessfully-to get Harry Hayward to pray with him on the evening of Hayward's hanging in 1895. WALTER N. TRENerRy, Murder in Minnesota: A Collection of True Cases 164 (1985).

41. When the sheriff released the drop, Williams immediately hit the floor because the rope was six inches too long. Three deputies, therefore, ran to the platform, pulled on the rope, and held Williams' feet off the floor for fourteen and a half minutes until he choked to death. After Williams was pronounced dead, spectators cut up the rope for souvenirs. TRENERRY, supra note 40 , at 163.

42. TRENERRY, supra note 40, at 156-67; Grant Moos, Newspaper Details of 1906 Hanging Made It State's Last, MiNNEAPOLIS STAR-TRIBUNE, Mar. 26, 1992, at 19A; see also Black, Botched Execution Did in Death Penalty, MINnEAPolis STAR-TRIBUNE, May 12,1990, at 8A (although capital punishment was not abolished in Minnesota until 1911, successive governors commuted every death sentence imposed after the botched execution).

43. 110 N.W. 867 (Minn. 1907).

44. TRENNERY, supra note 40 , at 166 . 
criminals with as much secrecy as possible, in order to avoid exciting an unwholesome effect on the public mind. For that reason it must take place before dawn, while the masses are at rest, and within an inclosure, so as to debar the morbidly curious. The number of witnesses is limited to the minimum, and, to give further effect to the purpose of avoiding publicity, newspaper reporters and representatives of the press are prohibited, and the publication of the event is limited to a mere statement of the fact that the execution took place. Publication of the facts in a newspaper would tend to offset all the benefits of secrecy provided for, and therefore the restriction as to publication has direct relation to and connection with the other matters embraced within the act. ${ }^{45}$

The court further stated:

The article in question is moderate, and does not resort to any unusual language, or exhibit cartoons for the purpose of emphasizing the horrors of executing the death penalty; but if, in the opinion of the Legislature, it is detrimental to public morals to publish anything more than the mere fact that the execution has taken place, then, under the authorities and upon principle, the appellant was not deprived of any constitutional right in being so limited. ${ }^{46}$

Although Minnesota's private execution statute became moot after capital punishment was abolished in that state in 1911, the law was repealed six years later out of concern that Williams' hanging could have been concealed from the public. ${ }^{47}$

Notwithstanding the challenge to Minnesota's private execution law, every state permitting capital punishment eventually adopted one type of private execution statute or another. Although some statutory loopholes allowed sentencing courts to order a public execution for prisoners convicted of certain crimes such as rape, ${ }^{48}$ the last public execution in the United States was carried out in Galena, Missouri on May 21, 1937.49

In the past few decades, public attitudes regarding public executions have been varied. Although public opinion surveys

45. Pioneer Press, 110 N.W. at 868.

46. Id. at 868-69.

47. Moos, supra note 42 , at $19 \mathrm{~A}$.

48. Mamantov, supra note 9, at 376-77.

49. Scott Armstrong, California Public-TV Station Seeks 'Live' Coverage of Executions, Christian SCI. MONITOR, May 10, 1991, at 4; see also Will, supra note 3, at C7. Notably, it has been contended that the hanging of Rainey Bethea on August 14, 1936, in Owensboro, Kentucky was the site of the last public execution in the United States. This contention is made on the grounds that the Missouri execution took place inside a high stockade and only people with special passes were admitted. 
have shown scant support for televised executions, ${ }^{50}$ both proponents and opponents of the death penalty have argued for a return to public executions. ${ }^{51}$ In addition, several journalists and death row inmates have taken legal action in an attempt to provide for televised executions. ${ }^{52}$ Akin to the public executions in the past, which inspired poetry and prose, ${ }^{53}$ these modern legal actions have prompted enormous media attention, ${ }^{54}$ resulting in

50. For example, a poll taken at the time of Gary Gilmore's execution revealed that $86 \%$ of those polled were opposed to viewing his execution on television. Tom Matthews \& Peter S. Greenberg, Gilmore's Countdown, NEwsweEK, Jan. 24, 1977, at 35; The Harris Survey (Louis Harris \& Associates, Inc.), cited in The DEATH PENALTY IN AMERICA, supra note 9, at 92. Among lawyers, a random sample of 600 lawyers found that $68 \%$ of lawyers felt executions should not be open to the public. Lauren R. Reskin, Majority of Lawyers Support Capital Punishment, A.B.A. J., Apr. 1985 , at 44 .

51. See, e.g., Valerie Richardson, All Bets Off on Effect of Executions on TV, WASH. Times, Apr. 10, 1991, at A1.

52. See infra Section IV.

53. In his novel, $A$ Tale of Two Cities, for example, Charles Dickens describes "Madame Defarge and her fellow 'knitting women' watching stoically as heads rolled in Paris in the 18th century." Olson \& Daly, Death on Video: Should Executions be on the Eleven O'Clock News, Manhattan Lawyer, Apr. 1991, at 13; see also CoOPER, supra note 11, at 77-87 (discussing the role of Dickens in the public execution controversy in England). For a literary discussion of poetry on the subject of hanging in England, see William B. Thesing, The Frame for the Feeling: Hangings in Poetry by Wordsworth, Patmore, and Housman, in EXECUTIONS AND THE BRITISH EXPERIENCE FROM THE 17TH TO THE 20TH CENTURY: A Collection of EsSAYs 123 (William B. Thesing ed., 1990).

Notably, in American Notes, published in 1842, Dickens also wrote on the subject of private executions:

The prison-yard . . . has been the scene of terrible performances. Into this narrow, grave-like place, men are brought out to die. The wretched creature stands beneath the gibbet on the ground; the rope about his neck; and when the sign is given, a weight at its other end comes running down, and swings him up into the air-a corpse.

The law requires that there be present at this dismal spectacle, the judge, the jury, and citizens to the amount of twenty-five. From the community it is hidden. To the dissolute and bad, the thing remains a frightful mystery. Between the criminal and them, the prison-wall is interposed as a thick gloomy veil. It is the curtain to his bed of death, his winding sheet, and grave. From him it shuts out life, and all the motives of unrepenting hardihood in that last hour, which its mere sight and presence is often allsufficient to sustain. There are no bold eyes to make him bold; no ruffians to uphold a ruffian's name before. All beyond the pitiless stone wall is unknown space.

Charles Dickens, AMERICAN Notes 63 (1842).

54. See Nightline: Making the Death Penalty Visible (ABC television broadcast, May 24, 1991). 
an "L.A. Law" episode 55 and a movie. ${ }^{56}$ The issue of televised executions has also sparked debate among American newspapers, legal periodicals and civil rights organizations. ${ }^{57}$

On the legislative front, attempts have been made to mandate televised executions. For example, in California, a bill which would require a warden to allow the media to be present at an execution and to televise it if the person being executed agreed, was introduced twice in a five month period. The first vote on the legislation, taken in May 1991, failed by a vote of twenty-four to thirty-seven. The second vote on the measure, taken in September 1991, failed by a vote of twenty-eight to forty, falling thirteen votes short of the forty-one votes needed for passage.

According to newspaper reports, each time the measure was heard it prompted "spirited debate." Assembly member Stan Statham and other Republicans who back capital punishment opposed the bill, while liberal Democrats, who oppose the death penalty, supported it. According to Statham: "There is a hidden agenda to this bill and that is to eliminate capital punishment as a law in California." However, Statham said he could support the proposal if re-enactments of the crimes committed by persons being executed were also shown. "If we're not forced to see the crime, we shouldn't be forced to see the execution," he said. On the other side of the aisle, Assembly member John Burton, the bill's author, said that although he opposes the death penalty, he does not know what reaction televised executions would provoke. ${ }^{58}$ "I have no idea how this issue will cut, but I

55. The "L.A. Law" episode depicted a man dying in a gas chamber. Howard Rosenberg, TV: A Witness for the Execution, L.A. TIMES, May 19, 1990, at F1.

56. The movie, "Somebody Has to Shoot the Picture," stars Roy Scheider, who plays a burned-out photographer hired by the condemned man to take his picture at the moment of execution. Ray Loynd, Shoot the Picture' Graphic on Death Row, L.A. TIMES, Sept. 8, 1990, at F13 (review).

57. See generally Patrick D. Philbin, Comment, "Pictures at an Execution," 9 Cooley L. REv. 137, 137 \& nn.4-8 (1992) (citing articles and disputes within two organizations, the American Civil Liberties Union and the National Coalition to Abolish the Death Penalty, over whether executions should be televised); see also Jef I. Richards \& R. Bruce Easter, Televised Executions: The High-Tech Alternative to Public Hangings, 40 U.C.L.A. L. REv. 381, 420 n.169 (1992) (noting dispute within the Young Lawyers Division of the American Bar Association).

58. Greg Lucas, Televised Executions Bill Dies: Assembly Votes It Down for a Second Time, S.F. CHroniCle, Sept. 4, 1991, at A14. 
believe people have a right to see [executions]," Burton said. ${ }^{59}$

There has even been activity in the United States Congress concerning public executions. In 1991, Senator Mark Hatfield of Oregon proposed legislation to require public executions for any sentence of death imposed under federal law. ${ }^{60}$ While the bill was referred to the Senate Judiciary Committee on May 23, $1991,{ }^{61}$ no further action was taken in Congress that year.

\section{CURRent Statutory Schemes}

Private execution statutes and implementing regulations fall into three general categories regarding the admission of witnesses to executions. ${ }^{62}$ First, in three states - Indiana, Wyoming, and Tennessee - statutes only allow persons either picked by the condemned or acting in an official capacity to witness the execution. ${ }^{63}$ Thus, in both Indiana and Wyoming, aside from the warden and other official witnesses, only ten friends or relatives of the condemned prisoner may be invited by the condemned to witness the execution. ${ }^{64}$ In Tennessee, aside from the official witnesses, only members of the condemned's family may be present to witness the execution. Furthermore, it is a Class C misdemeanor in Tennessee for the warden of the state penitentiary to permit any person or persons, other than someone au-

59. Id.; see also TV Bill Killed, NAT'L L.J., Sept. 16, 1991, at 6. Although similar bills were under consideration in Florida and Georgia, no actions were taken in 1991. Bill Halldin, House Panel Foresees Call for TV Executions, TAMPA TRIB., July 9, 1991, at 1; $1991 \mathrm{Ga}$. H.B. 110, available in LEXIS, Genfed Library, Bills File (introduced to House Committee on State Institutions and Property on January 15, 1991).

60. S. 1155, 102d Cong., 1st Sess. (1991); Jonathan Sherman, Pictures At an Execution, N.Y. Times, May 3, 1991, at A31 ("In 1985 . . . Senator Mark Hatfield of Oregon suggested that the public would turn against the death penalty once it peered into the execution chamber.").

61. 137 CONG. REC. S6667 (daily ed. May 23, 1991) (statement of Sen. Hatfield).

62. See generally Mamantov, supra note 9, at 378-80. Three states with capital punishment statutes, Delaware, Idaho, and Washington, do not have private execution statutes that fit into one of these three categories. While the Washington statute, which states that executions must be conducted in private, does not specify who can attend such executions, the Idaho statute does not specify at all who can be in attendance at an execution. See WASH. REv. CODE ANN. § 10.95.180 (West 1990); IDAHo CODE $\S 19-2716$ (1987). The Delaware statute permits the sentencing court to set the execution conditions. See DEL. CODE ANN. tit. 11, § 4209(f) (1987).

63. IND. CODE ANN. § 35-38-6-6 (Bums 1985); TENN. CODE ANN. § 40-23-116 (1982); WYO. STAT. § 7-13-908 (1987 and Supp. 1992).

64. IND. CODE ANN. § 35-38-6-6 (Burns 1985); Wyo. STAT. § 7-13-908 (1987 and Supp. 1992). 
thorized by statute, to witness an execution. ${ }^{65}$

Second, twelve private execution statutes require that a given number of witnesses attend an execution, although they are silent regarding who those witnesses may be. These provisions generally require the warden or superintendent of the state prison to select the witnesses, ${ }^{66}$ although some state laws do not specifically delegate this task to anyone. ${ }^{67}$ A majority of these statutes specifically authorize the condemned prisoner to invite friends or relatives to be present at the execution. ${ }^{68}$

Finally, the least restrictive type of statutes or regulations

65. Tenn. Code AnN. § 40-23-116(b) (1982).

66. ARIZ. Rev. StAT. ANN. § 13-705 (1989) (superintendent shall invite "at least twelve reputable citizens of his selection"); CoLo. REv. STAT. § 16-11-404 (1990) ("such guards, attendants, and other persons as the executive director or his designee in his discretion deems desirable, not to exceed fifteen persons"); MASs. ANN. LAwS ch. 279, $\S 65$ (Law. Co-op. 1992) ("with the approval of the superintendent, not more than three other persons"); Mo. ANN. STAT. \$ 546.740 (Vernon 1987 \& Supp. 1992) (chief administrative officer of the correctional facility shall invite "at least twelve reputable citizens, to be selected by him"); NEB. REV. STAT. § 29-2534 (1989) ("such other persons, not exceeding six in number, as the warden may designate"); NEV. REV. STAT. \$ 176.355 (1991) (director of the department of prisons shall invite "not less than six nor more than nine reputable citizens"); N.H. REv. STAT. ANN. § 630:6 (1986) ("the sheriff of the county in which the person was convicted ... may admit other reputable citizens not exceeding 12"); N.M. STAT. ANN. \$31-14-15 (Michie 1984) (warden must invite "at least twelve reputable citizens, to be selected by him").

67. ARK. CODE ANN. § 16-90-502(d)(2) (Michie 1987) ("At the execution there shall be present ... a number of respectable citizens numbering not fewer than six (6) nor more than twelve (12)."); Ill. ANN. STAT. ch. 38, para. 119-5(d) (Smith-Hurd 1990 \& Supp. 1992) (the execution shall be conducted in the presence of " 6 other witnesses who shall certify the execution of the sentence"); LA. REv. STAT. ANN. \$15:570 (West 1992) ("not less than five nor more than seven other witnesses"); MD. ANN. CODE art. 27, $\$ 73$ (1992) (an execution shall take place in the presence of "a number of respectable citizens numbering not less than six or more than twelve"); MONT. CODE ANN. § 46-19-103(5) (1987) ("[t]he warden must allow the execution to be observed by 12 witnesses"); N.C. GEN. STAT. § 15-190 (1983) ("At such execution there shall be present ... six respectable citizens ..."); VA. CODE ANN. § 53.1-234 (Michie 1991) ("At the execution there shall be present ... a least six citizens who shall not be employees of the Department.").

68. ARIZ. REV. STAT. ANN. § 13-705 (1989) ("superintendent shall . . permit ... any persons, relatives or friends, not to exceed five, to be present at the execution"); CaL. Penal CODE $\S 3605$ (West 1993) ("any persons, relatives or friends, not to exceed five"); MASS. ANN. LAws ch. 279, § 65 (Law. Co-op. 1992) ("the immediate members of the family of the prisoner" can be present); MO. ANN. STAT. $§ 546.740$ (Vernon 1992) ("any person, relatives or friends, not to exceed five, to be present at the execution"); MONT. CODE ANN. § 46-19-103(5) (1987) (three witnesses "may be designated by the person to be executed"); NEB. REv. STAT. § 29-2534 (1989) ("such other persons, not exceeding three in number as the prisoner may designate"); N.M. STAT. ANN. § 31-14-15 (Michie 1984) ("any person, relatives or friends, not to exceed 
specifically authorize press attendance at executions. However, of the states that allow media attendance, ${ }^{69}$ no state has a statute or regulation explicitly authorizing the audio or video recording of an execution. Indeed, many states in this category specifically prohibit such audio-visual reproduction. ${ }^{70}$ In this least restrictive type of regulatory scheme, several states specifically permit relatives or friends of the condemned person to be present at the execution, ${ }^{71}$ while other statutes do not specify which witnesses

five"); N.C. GEN. STAT. $§ 15-190$ (1983) ("any relatives of such person, convict or felon").

69. See AlA. CodE $\S 15-18-83(a)(6)$ (1982) ("Such newspaper reporters as may be admitted by the warden . . . ."); CONN. GEN. STAT. ANN. $\S 54-100$ (West 1985) ("[R]epresentatives of not more than five newspapers in the county where the crime was committed, and one reporter for each of the daily newspapers published in the city of Hartford."); FLA. STAT. ANN. § 922:11(2) (West 1985) ("Representatives of news media may be present under rules approved by the Secretary of Corrections."); FlA. ADMIN. CODE ANN. ch. 33.15.001 (1990); Ky. REv. STAT. ANN. § 16-431.250 (Michie/Bobbs-Merrill Supp. 1992) ("[N]ine (9) representatives of the news media ...."); MISS. CoDE ANN. \$ 99-19-55(2) (Supp. 1992) ("[B]ona fide members of the press, not to exceed eight (8) in number . ..."); N.J. STAT. ANN. \& 2C:49-7(c) (West Supp. 1992) ("The commissioner shall permit eight representatives of the news media to be present at the execution . ..."); OHIO REv. CODE ANN. § 2949.25(F) (Baldwin 1992) ("Representatives of not exceeding three newspapers in the county where the crime was committed, one reporter for each of the daily newspapers published in the city of Columbus, and such other representatives of the news media as the director of rehabilitation and correction authorizes."); OHIO ADMIN. CODE § 5120-9-54 (1989); OKLA. STAT. ANN. tit. 22, §1015 (West 1986) ("[N] ewspapermen from recognized newspapers, press, and wire services, and radio reporters ...."); PA. STAT. ANN. tit. 61, $\$ 2125$ (Supp. 1992) ("not more than six duly accredited representatives of the daily newspapers ...."); S.C. CODE ANN. § 24-3-550 (Law. Co-op. Supp. 1992) ("[A] group of not more than five representatives of the South Carolina media . ..."); S.D. CoDified LAwS ANN. § 23A-27A-34 (1988) ("[A]t least one member of the news media ...."); TEx. CRIM. Proc. Code ANN. § 43.20 (West 1979); Texas Department of Corrections, Policy No. 1-82 (1982) (cited in Mamantov, supra note 9, at 380 n.37); UTAH CODE ANN. § 77-19-11(4) (1990) ("[N]ine members of the press and broadcast news media ... provided that the selected news media members serve as a pool for other members of the news media as a condition of attendance.").; $c f$. KQED Inc. v. Vasquez, 18 Media L. Rep. (BNA) 2323, 2326, No. C-90-1383 RHS (June 17, 1991) (in California, journalists cannot be barred from the execution chamber); 1963-64 Ops. Ga. Att'y Gen. 346 (if the condemned person should express a desire to have some member of the press present, the department would be legally authorized to admit him).

70. Fla. Admin. Code AnN. ch. 33.15.002 (1990); Ky. Rev. Stat. AnN. § 16431.250 (Michie/Bobbs Merrill Supp. 1992); MIss. CODE ANN. § 99-19-55(2) (Supp. 1992); OHIo ADMIN. CODE $§ 5120-9-54(B)$ (1989); S.C. CODE ANN. § 24-3-550 (Law. Co-op. Supp. 1992); Texas Department of Corrections, Policy No. 1-82 (1982) (cited in Mamantov, supra note 9, at 380 n.37); UTAH CODE ANN. \$ 77-19-11(5)(a) (1990).

71. AI.A. CODE $\S 15-18-83(a)(7)$ (1982) ("Any of the relatives or friends of the condemned person that he may request, not exceeding five in number."); CoNN. GEN. 


\section{can be present at the execution. ${ }^{72}$}

Notably, most states with private execution statutes specifically permit a priest, minister, or religious representative of the condemned to attend the execution. ${ }^{73}$ The condemned's attorney has the right to attend a client's execution in some states. ${ }^{74}$

STAT. ANN. $\S 54100$ (West 1985) ("such other adults, as the prisoner may designate, not exceeding three in number"); GA. CODE ANN. § 17-10-41 (1990) ("the convicted person may request the presence of . . . a reasonable number of relatives and friends, provided that the total number of witnesses appearing at the request of the convicted person shall be determined by the commissioner of corrections"); KY. REV. STAT. ANN. § 16-431.250 (Michie/Bobbs Merrill Supp. 1992) ("three (3) other persons selected by the condemned"); Miss. CODE ANN. \$ 99-19-55(2) (Supp. 1992) ("the commissioner may permit two (2) members of the condemned person's immediate family as witnesses, if they so request"); OHIO REV. CODE ANN. § 2949.25(E) (Baldwin 1992) ("not more than three other persons, to be designated by such prisoner"); ОHIO ADMIN. CODE $\S 5120-9-54(A)(6)$ (1989) (" $[t]$ hree persons designated by the prisoner who are not confined in any state institution"); OKLA. STAT. ANN. tit. 22, § 1015 (West 1986) ("any persons, relatives or friends, not to exceed five, as the defendant may name"); S.D. CoDIFIED LAWS ANN. § 23A-27A-35 (1988) ("any relatives or friends requested by the defendant not exceeding five"); TEX. CRIM. Proc. CoDE ANN. $\S 43.20$ (West 1979) ("any of the relatives or friends of the condemned person that he may request, not exceeding five in number"); UTAH CODE ANN. § 77-19$11(2)$ (d) (1990) (friend or relatives "designated by the defendant, not exceeding a total of five persons"). But see N.J. STAT. ANN. § 2C:49-7(d) (West Supp. 1992) ("The commissioner shall not authorize or permit any person who is related by either blood or marriage to the sentenced person or to the victim to be present at the execution ....").

72. Pa. Stat. ANN. tit. 61, $§ 2125$ (Supp. 1992) ("six reputable adult citizens selected by such warden"); S.C. CODE ANN. § 24-3-550 (Law. Co-op. Supp. 1992) ("a group of not more than two respectable citizens . . . designated by the commissioner").

73. Ala. CODE § 15-18-83(a)(4) (1982); ARIz. REV. STAT. ANN. § 13-705 (1989); ARK. Code AnN. § 16-90-502(d)(2) (Michie 1987); Cal. Penal Code § 3605 (West Supp. 1993); CoNN. GEN. STAT. ANN. § 54-100 (West 1985); Fla. STAT. ANN. § 922:11(2) (West 1985); GA. CODE ANN. § 17-10-41 (1990); IND. CODE ANN. § 35-38-6-6 (Burns 1986); KY. REv. STAT. ANN. § 16-431.250 (Michie/Bobbs Merrill Supp. 1992); LA. Rev. STAT. ANN. § 15:570 (West 1992); MD. ANN. CodE art. 27, § 73 (1992); MASs. ANN. LAws ch. 279, § 65 (Law. Co-op. 1992); Miss. CODE ANN. § 99-19-55(2) (Supp. 1992); Mo. ANN. STAT. § 546.740 (Vernon Supp. 1992); NEb. REv. StAT. § 29-2534 (1989); N.H. REV. STAT. ANN. § 630:6 (1986); N.M. STAT. ANN. § 31-14-15 (Michie 1984); N.C. GEN. STAT. § 15-190 (1983); OHo Rev. Code ANN. § 2949.25(E) (Baldwin 1992); OHIo ADMIN. CoDE § 5120-954(A)(5) (1989); OKLA. STAT. ANN. tit. 22, § 1015 (West 1986); PA. STAT. ANN. tit. 61, § 2125 (Supp. 1992); S.C. CODE ANN. § 24-3-550 (Law. Co-op. Supp. 1992); S.D. CODIFIEd LAWS ANN. § 23A-27A-35 (1988); TENN. CODE ANN. § 40-23-116(b)(3) (1982); Tex. Crim. Proc. Code ANN. \$ 43.20 (West 1979); UTAH CoDE ANN. \$ 7719-11(2)(d) (1990); VA. CODE ANN. § 53.1-234 (Michie 1991); WYo. STAT. § 7-13908 (Supp. 1992).

74. ARK. CODE ANN. $\S 16-90-502(d)(2)$ (Michie 1987); Fla. Stat. ANN. § 922:11(2) (West 1985); GA. CODE ANN. § 17-10-41 (1990); MD. ANN. CoDE art. 
Some states' statutes expressly prohibit minors from witnessing an execution. ${ }^{75}$ In other states, convicts are expressly prohibited from witnessing an execution, ${ }^{76}$ or the identity of executioners is protected by statute. ${ }^{77}$ In one state, it is a misdemeanor to have photographic or recording equipment at the execution site while the execution is taking place, ${ }^{78}$ while in another state it is illegal to print or publish the details of an execution; only the fact that the criminal was executed can be printed or published. ${ }^{79}$

27, § 73 (1992); N.C. GEN. STAT. § 15-190 (1983); S.C. CODE ANN. § 24-3-550 (Law. Co-op. Supp. 1991); VA. CodE ANN. § 53.1-234 (Michie 1991). Cf. N.H. Rev. STAT. ANN. $\S 630: 6$ (1986) (sheriff has the discretion to admit the condemned prisoner's counsel).

75. ARIZ. REV. STAT. ANN. § 13-705 (1989) ("nor shall any minor be allowed to witness the execution"); CAL. PENAL CODE $\S 3605$ (West Supp. 1993) ("nor can any person under 18 years of age be allowed to witness the execution"); CONN. GEN. STAT. ANN. § 54-100 (West 1985) ("such other adults, as the prisoner may designate"); LA. REV. STAT. ANN. $§ 15: 570$ (West 1992) ("No person under the age of eighteen years shall be allowed within the execution room during the time of execution."); Mo. ANN. STAT. § 546.740 (Vernon Supp. 1992) ("no person under twentyone years of age shall be allowed to witness the execution"); NEV. REV. STAT. $\S 176.355$ (1991) (director of the department of prisons shall invite "not less than six nor more than nine reputable citizens over the age of 21 years, to be present at the execution"); N.J. STAT. ANN. § 2C:49-7(a) (West Supp. 1992) ("six adult citizens"); N.M. STAT. ANN. §31-14-15 (Michie 1984) (no person "under age" is allowed to witness an execution); PA. STAT. ANN. tit. 61, § 2125 (Supp. 1992) ("six reputable adult citizens selected by such warden"); UTAH CODE ANN. § 77-19-11(7)(b) (1990) ("Any person younger than 18 years of age may not attend."). Cf. S.D. CoDIFIED LAwS ANN. § 23A-27A-36 (1988) ("The warden . . . shall not permit the presence of any person under the age of eighteen years, unless a relative, and no relatives of tender years shall be admitted.").

76. AlA. CODE § 15-18-83(b) (1982); OHIO REV. CODE ANN. § 2949.25(E) (Baldwin 1992); OHIo AdmIN. CODE § 5120-9-54(A)(5)-(6) (1989); TeX. CRIM. Proc. Code ANN. $\S 43.20$ (West 1979).

77. Ill. ANN. Stat. ch. 38, para. 119-5(e) (Smith-Hurd Supp. 1992); N.J. STAT. ANN. $\S 2$ C:49-7(a) (West Supp. 1992). For example, according to the Illinois private execution statute:

The identity of executioners and other persons who participate or perform ancillary functions in an execution and information contained in records that would identify those persons shall remain confidential, shall not be subject to disclosure, and shall not be admissible as evidence or be discoverable in any action of any kind in any court or before any tribunal, board, agency, or person. In order to protect the confidentiality of persons participating in an execution, the Director of Corrections may direct that the Department make payments in cash for such services.

ILL. ANN. STAT. ch. 38, para. 119-5(e) (Smith-Hurd Supp. 1992).

78. UTAH CODE ANN. $\$ 77-19-11(5)(\mathrm{b})$ (1990).

79. ARK. CODE ANN. \& 16-90-504 (Michie 1987) ("No newspaper or person shall print or publish the details of the execution of criminals under $\S \S 12-28-102,16-90$ $501,16-90-502$, and 16-90-505. Only the fact that the criminal was executed shall be 


\section{Challenges to Private Execution Statutes}

\section{A. Federal Challenges}

In deciding Garrett v. Estelle, ${ }^{80}$ the United States Court of Appeals for the Fifth Circuit became the first appellate court to address the question of whether a state can prohibit the filming of an execution. ${ }^{81}$ In Garrett, the plaintiff, a television reporter, requested permission from the Texas Department of Corrections to film the first execution in Texas since 1964 and to film interviews with condemned prisoners then confined on "death row."82 Rejecting these requests, Texas officials cited Article $43.17^{83}$ and Article $43.20^{84}$ of the Texas Code of Criminal Proce-

printed or published."); ARK. CODE ANN. § 16-90-502(d)(1) (1987) ("No execution of any person convicted in this state of a capital offense shall be public; but it shall be private. Any officer convicted of violating this subdivision shall be fined in any sum not less than one hundred dollars (\$100)."). A statute repealed in the State of Washington in 1982 considered the publication of the details of an execution as obscenity and made such publication punishable as such. See WaSh. REV. CODE ANN. $\S 9.68 .020$ (West 1988) (noting the law was repealed by 1982 Wash. Laws, ch. 184, $\S 11$ (effective April 1, 1982)).

80. 556 F.2d 1274 (5th Cir. 1977), cert. denied, 438 U.S. 914 (1978). For a thorough discussion of the Garrett case, see Comment, Broadcasters' News-Gathering Rights Under the First Amendment: Garrett v. Estelle, 63 IowA L. REv. 724 (1978) and Katherine A. Mobley, Case Note, 11 CREIGHTON L. REv. 1031 (1978). For a compelling argument that Garrett was wrongly decided, see Jerome T. Tao, Note, First Amendment Analysis of State Regulations Prohibiting the Filming of Prisoner Executions, 60 GEO. WASH. L. REV. 1042 (1992).

81. Garrett, 556 F.2d at 1275.

82. Id. at 1276.

83. Article 43.17 provides that:

Upon the receipt of such condemned person by the Director of the Department of Corrections, the condemned person shall be confined therein until the time for his execution arrives, and while so confined, all persons outside of said prison shall be denied access to him, or her except his or her physician and lawyer, who shall be admitted to see him or her when necessary to his or her health or for the transaction of business, and the relatives, friends and spiritual advisors of the condemned person, who shall be admitted to see and converse with him or her at all proper times, under such reasonable rules and regulations as may be made by the Board of Directors of the Department of Corrections.

Garrett, 556 F.2d at 1276 n.2.

84. According to Article 43.20:

The following persons may be present at the execution: the executioner, and such persons as may be necessary to assist him in conducting the execution; the Board of Directors of the Department of Corrections, two physicians, including the prison physician, the spiritual advisor of the condemned, the chaplains of the Department of Corrections, the county judge and sheriff of the county in which the Department of Corrections is situated, and any of 
dure, neither of which specifically authorized a reporter to film executions or to film interviews with inmates. Furthermore, in denying the television reporter's requests, Texas officials relied on a "media policy"85 regarding executions that had been developed by the Texas Department of Corrections. ${ }^{86}$

In holding in Garrett that a television reporter has no right to film Texas executions, the Fifth Circuit explicitly rejected three arguments made by the reporter. First, the court rejected the contention that Garrett could find his right to film executions in the First Amendment. ${ }^{87}$ Relying on the Supreme Court's decisions in the companion cases of Pell v. Procunier ${ }^{88}$ and Saxbe v. Washington Post Co., ${ }^{89}$ which held that the government is not required to give the press special access to information not shared by the public generally, the Garrett court stated that "the first amendment does not invalidate nondiscriminatory prison access regulations." 90 According to the Fifth Circuit, "Despite the unavailability of film of the actual execution the public can be fully informed; the free flow of ideas need not be inhibited."91

Second, the Fifth Circuit in Garrett summarily rejected Garrett's argument that the state's prohibition of his filming of executions denied him equal protection of the law, as other members of the press were allowed to utilize their "usual reporting tools." $" 92$ According to the court:

The Texas media regulation denies Garrett use of his camera, and it also denies the print reporter use of his camera, and the radio re-

the relatives or friends of the condemned person that he may request, not exceeding five in number, shall be admitted. No convict shall be permitted by the prison authorities to witness the execution.

Garrett, 556 F.2d at 1276 n.2.

85. Among other things, the "media policy" stated that "[n]o recording devices, either audio or video, [shall] be permitted either in the execution chamber or monitor room." Garrett, 556 F.2d at 1276 n.1. The policy further provided that "[n]o video tapes shall be made from the monitor system." Id.

86. See Garrett, 556 F.2d at 1276; see also Garrett v. Estelle, 424 F. Supp. 468, $469-70$ (N.D. Tex. 1977), rev'd, 556 F.2d 1274 (5th Cir. 1977) (discussing the development of the Texas "media policy").

87. Garrett, 556 F.2d at 1279.

88. 417 U.S. 817 (1974).

89. 417 U.S. 843 (1974).

90. Garrett, 556 F.2d at 1278 .

91. Id.

92. Id. at 1279. 
porter use of his tape recorder. Garrett is free to make his report by means of anchor desk or stand-up delivery on the TV screen, or even by simulation. There is no denial of equal protection. ${ }^{93}$

Lastly, the Fifth Circuit in Garrett rejected the notion that the proposed closed circuit television broadcast of the execution was a "publication." Discarding this "prior restraint" attack on the Texas media regulation, the court merely stated that "[a]ccess for the purpose of filming is not provided, and the first amendment does not require that it be provided."94

In marked contrast, the judgment of the federal district court in Garrett ${ }^{95}$ - which the Fifth Circuit reversed - would have given the press a First Amendment right to televise executions. Describing capital punishment as "the ultimate act" of the state, ${ }^{96}$ the lower court in Garrett would have permitted at least one television reporter with a camera to witness every execution. ${ }^{97}$ Regarding such televised executions, the district court stated:

It is argued that such broadcasts would be an "offense to human dignity," "distasteful," or "shocking." This may well be true, but the question here is whether such decisions are to be made by government officials or by television news directors. The state says, in effect, that "We, the government, have determined that the governmental activity in this instance is not fit to be seen by the people on television news." In addition to being ironic, such a position is dangerous. If government officials can prevent the public from witnessing films of governmental proceedings solely because the government subjectively decides that it is not fit for public viewing, then news cameras might be barred from other public facilities where public officials are involved in illegal, immoral, or other improper activities that might be "offensive," "shocking," "distasteful" or otherwise disturbing to viewers of television news. ${ }^{98}$

Ultimately, the lower court in Garrett would have relied on the "people themselves" to shield themselves from unacceptable reports by using "selective television viewing."

Paralleling the approach of the Fifth Circuit in Garrett, the

93. Id.

94. $I d$.

95. Garrett v. Estelle, 424 F. Supp. 468 (N.D. Tex. 1977), rev'd, 556 F.2d 1274 (5th Cir. 1977).

96. Id. at 471.

97. Id. at 472 .

98. Id. at $472-73$ (footnote omitted).

99. Id. at 473 . 
court in Kearns-Tribune v. Utah Board of Corrections ${ }^{100}$ also rejected the notion that the press has an affirmative right to attend executions. ${ }^{101}$ In noting that Utah law denied the general public the right to attend executions, ${ }^{102}$ the court framed the issue as "whether the plaintiffs have a constitutional right of access to attend and report on the actual execution of Gary Mark Gilmore." 103 As did the Fifth Circuit in Garrett, the court in Kearns-Tribune cited Pell and Saxbe to conclude that the plaintiffs had no First Amendment right to attend executions. ${ }^{104}$ Likewise, the court in Kearns-Tribune also rejected a challenge to the Utah statute under the Equal Protection clause of the Fourteenth Amendment. Referring to "institutional discipline," "security," and "reasonable deference to the privacy of the condemned man" as rational concerns, ${ }^{105}$ the court concluded:

The plaintiffs have not established any grounds to justify "strict scrutiny" of this state legislation. The court, therefore, has applied a rational basis analysis under the Equal Protection Clause of the Fourteenth Amendment to determine whether the Utah statute in question unconstitutionally excludes the plaintiffs from attendance at the Gilmore execution. The plaintiffs have not met their burden that [the Utah statute] lacks a rational basis. ${ }^{106}$

More recently, KQED San Francisco, one of the largest public television stations in northern California, sued the state of California to allow photographic coverage of the execution of Robert Alton Harris. ${ }^{107}$ The original lawsuit contended that

100. 2 Media L. Rep. (BNA) 1353 (D. Utah 1977).

101. Id. at 1353.

102. The actual statute provided:

The warden must invite the presence of a physician and the county attorney of the county; and he shall, at the request of the defendant, permit such ministers of the gospel, not exceeding two, as the defendant may name, and any persons relatives or friends, not to exceed five, to be present at the execution, together with such peace officers as he may think expedient to witness the execution. But no other persons than those mentioned in this section shall be present at the execution, nor shall any person under age be permitted to witness the same.

UTAH CODE ANN. § 77-36-18 (Supp. 1975).

103. Kearns-Tribune, 2 Med. L. Rptr. (BNA) at 1353.

104. Id. at 1353-54.

105. Id. at 1354 .

106. Id.

107. Lance Williams, Trial to Open on Executions on TV, San Francisco Examiner, Mar. 24, 1991, at A1. For further discussion regarding the suit by KQED, see Steve Keeva, Watching a Killer Die: California TV Station Sues to Televise Execution, A.B.A. J., Oct. 1990, at 24. 
Daniel Vasquez, San Quentin's warden, had unlawfully discriminated against broadcasters when he ruled in 1990 that only newspaper reporters could watch the execution of Harris, who later won a stay of execution. ${ }^{108}$ Indeed, before a bench trial was scheduled to begin on March 25, 1991, United States District Court Judge Robert Schnacke had "rejected a bid by state authorities to dismiss the suit, saying there must be 'appropriate balancing' between concerns over security and privacy surrounding an execution and the rights of a free press." 109

However, a week before the bench trial was scheduled to begin, San Quentin's warden barred all journalists from attending future executions. ${ }^{10}$ This action, which reversed the prison's long-standing policy of allowing journalists without cameras or recorders to witness executions, ${ }^{111}$ prompted Judge Schnacke to declare, on the first day of trial, that KQED's suit against California might be moot. In a preliminary finding, Schnacke said that he was "quite satisfied that neither the press nor the public has a First Amendment right" to attend executions. ${ }^{112}$

Without issuing a definitive ruling, however, Judge Schnacke began the trial and frequently questioned KQED news

108. Williams, supra note 107 , at A1.

109. Philip Hager, Trial Ordered Over Right to Televise Executions, L.A. TIMES, Nov. 10, 1990, at A26. According to the news report, State Deputy Attorney General Karl Mayer defended the ban on televised executions to protect the "identities of correctional staff members, inmates' relatives or other witnesses who might later be subject to harassment or threats." Id. Conversely, in court briefs, KQED attorney William Bennett Turner argued "that with modern technology, a camera could record an execution unobtrusively and that the public had a right to view the event as the 'ultimate sanction' of the criminal justice system." Id. For a recent law review article written by the two attorneys for KQED, see William Bennett Turner \& Beth S. Brinkmann, Televising Executions: The First Amendment Issues, 32 SANTA ClaRA L. REv. 1135 (1992).

110. Williams, supra note 107 , at A23.

111. Philip Hager, Trial Tests Media's Right at Executions, L.A. TIMEs, Mar. 26, 1991, at A3. Although California's Penal Code requires only that "at least [twelve] 12 reputable citizens" of the warden's choosing attend an execution, California has an unwritten policy of admitting up to twenty-five journalists at executions. See Mamantov, supra note 9, at 379 n.37 (citing letter from Phillip Guthrie, Assistant Director for Public Information of the California Department of Corrections, stating that California's unwritten policy of admitting up to 25 media representatives may be formally implemented).

112. Rosenfeld, Judge Frowns on TV Deaths, San Francisco Examiner, Mar. 26, 1991, at A2. 
director Michael Schwarz.113 At one point, for example, in addressing a comment to Schwarz, Schnacke remarked that recording sound in the execution chamber would make the film "much more dramatic."114 He continued: "That's what you're hoping for. . . . It would be much more saleable."115 In reply, Schwarz said that KQED's motives were journalistic, not commercial. When Schnacke asked further who would be the "supreme arbiter" of good taste in the film's airing, Schwarz answered, "the public."116 Nevertheless, Judge Schnacke suggested that the public would probably exercise poor taste in watching executions. He noted that "[s]omeone once said that no one went broke underestimating the taste of the American people."117

On the second day of trial, a former California prison director, Raymond Procunier, testified for KQED. Procunier testified that there was no reason to bar the media from covering executions. He noted that "[c]orrections people have a tendency to set moral standards and meddle in areas that are none of their business." In addition, Procunier stated that prison officials' concerns that a broadcast journalist might hurl a camera against the gas chamber windows "bordered on the bizarre."118 On the issue of inmate reaction to televised executions, Procunier suggested that watching such executions would not make inmates more unruly than if they read newspaper accounts, and that inmates would not be more inclined to retaliate against prison officials. ${ }^{119}$

113. Id. Schwarz said the station planned to film inmates' faces during the 10 to 15 minutes it takes the poison gas to kill them, and would air the film late in the evening to avoid young viewers. Id.

114. Id.

115. Id.

116. Id.

117. Id.

118. Rosenfeld, Ex-state Prison Head Backs Using Cameras at Executions, San Francisco Examiner, Mar. 27, 1991, at A7. When Deputy Attorney General Karl Mayer asked Procunier whether a camera could crack the gas chamber windows, Judge Schnacke interjected that "there may be such a thing in this world as a suicidal cameraman." Id. Responding to Mayer's concern, however, Procunier replied that a camera stand could easily be secured to the floor. Id. Procunier also added that reporters are often allowed to bring cameras on prison tours and that, in his 43 years in corrections, no camera operator has ever attempted to hide contraband in equipment. Id.

119. Id. 
On the next day of the trial, the warden of San Quentin, Daniel Vasquez, countered with testimony of his own. According to Vasquez, televised executions should be banned for a "host" of reasons. ${ }^{120}$ First, Vasquez feared that televised images of the dying would cause "radicals" to identify guards and take revenge. "If we're talking about taking the lives of human beings, I'm afraid that some radicalism might be directed against my staff," he said. ${ }^{121}$ Second, Vasquez stated that the presence of cameras in the execution chamber would disrupt the "decorum" of the proceedings. Suggesting that a cameraman might even throw a camera against the gas chamber's windows, Vasquez asked: "What if he decided he was going to throw it against the glass? What if there was something in it and he was going to throw it and try and stop the execution?"122 Finally, contradicting Procunier's testimony of the previous day, Vasquez suggested that executions agitate inmates. In particular, Vasquez testified that "it was a lot more tense" throughout San Quentin before Robert Alton Harris' execution which was scheduled to occur in April 1990. Vasquez warned that inmates could identify prison staff members from television and then retaliate against them, either inside the prison or through friends on the outside. ${ }^{123}$

Ultimately, before a filled courtroom, Judge Schnacke announced that California authorities could bar cameras from the gas chamber since they pose a risk to prison security. ${ }^{124}$ In particular, Judge Schnacke said that testimony from the March trial convinced him that the television broadcast of an execution, even if it was broadcast some time after the actual event, could lead to prison riots. Still photographs or a live broadcast seen by inmates with television sets could spark "a severe reaction," he said. ${ }^{125}$ Moreover, Schnacke feared that cameras might reveal

120. Rosenfeld, Warden Afraid of Revenge on Guards if Executions on $T V$, San Francisco Examiner, Mar. 28, 1991, at A5.

121. Id. Vasquez made this remark after noting that "in this day and age" animal rights activists had burned a barn merely because its owner raised veal. Id.

122. Id.

123. Id.

124. Philip Hager, U.S. Judge Upholds Ban on TV Cameras at Executions, L.A. TIMES, June 8, 1991, at A1. For an article asserting that the KQED case was wrongly decided, see Jeff Angeja, Note, Televising California's Death Penalty: Is there a Constitutional Right to Broadcast Executions?, 43 HASTINGS L.J. 1489 (1992).

125. Hager, supra note 124, at A25. 
the identities of guards and other staff members, thereby jeopardizing their safety and the safety of their families. ${ }^{126}$ In addition, Schnacke added that photographers' heavy equipment could also be used to break the glass shielding the gas chamber at San Quentin, noting that "[t]he warden is not required to trust anybody. It's no answer to say the press are all nice people and would never do anything irrational." 127 Thus, in echoing nearly all of the concerns of the San Quentin warden at the March trial, Judge Schnacke handed the warden broad discretion. "[P]rison officials are the experts," he stated. "Their reasonable concerns must be accommodated. They not unreasonably see risks permitting cameras. Prohibition of cameras is a reasonable and valid regulation." 128

However, Judge Schnacke also decided that rules barring

126. Judge Schnacke expressed the view that "no rational way appears to prevent cameras that are [at an execution] from getting either intentionally or inadvertently photographs of the prison personnel." KQED Inc. v. Vasquez, 18 Media L. Rep. (BNA) 2323, 2326 (N.D. Cal. 1991).

127. Hager, supra note 124, at A25.

128. Rick DelVecchio, Judge Upholds Ban on Cameras at Executions, S.F. CHRONICLE, June 8, 1991, at A1. In KQED, it was alleged that the process for selecting execution witnesses in California was unconstitutional based upon the well-established rule that a law which "vests unbridled discretion in a government official over whether to permit or deny expressive activity" is invalid on its face. Plaintiffs Trial Brief at 2, KQED, Inc. v. Vasquez, No. C90-1383RHS (N.D. Cal. 1991) (citing City of Lakewood v. Plain Dealer Pub. Co., 486 U.S. 750, 755 (1988) and Shuttlesworth v. Birmingham, 394 U.S. 147, 151 (1969)). Although the California law gave the warden the discretion to choose any "reputable citizens" to witness the execution, the San Quentin warden in $K Q E D$ allowed the Governor's Press Secretary, Robert Gore, to select the press witnesses. Perhaps the most questionable move on Gore's part was to add to the favored list the politically conservative Sacramento Union, one of the few news organizations that had not even requested a permit to witness Robert Alton Harris' execution. In so doing, Gore passed over The Sacramento Bee, a paper with four to five times the circulation of The Sacramento Union. Although Gore testified that he couldn't recall why he favored the Union over the Bee, he admitted that he was "well aware" of the "extremely negative" columns being written about the Governor by the Bee's political columnist. It was undisputed that Gore's primary job was to get favorable press coverage for the Governor and his programs. Plaintiff's Post-Trial Brief at 21-22, KQED, Inc. v. Vasquez, 18 Media L. Rep. (BNA) 2323 (N.D. Cal. 1991 No. C90-1383RHS); see also id. at 13 (one of the warden's criteria for selecting non-press witnesses was their disinclination to talk with reporters). Notwithstanding the actions of Gore, Judge Schnacke found that the method of selecting media representatives was "reasonable and appropriate." KQED Inc. v. Vasquez, 18 Media L. Rep. (BNA) 2323, 2327 (N.D. Cal. 1991). This issue is beyond the scope of this Article. 
all reporters from executions were "irrational and capricious."129 "The press has always been there, and the First Amendment makes it pretty clear it is important to have a process of news gathering," Judge Schnacke said. Adding that the warden's action in barring all press attendance from executions "was more emotional than rational,"130 Judge Schnacke emphasized: "It does appear that where there is a long custom and practice of accommodating the press, and where that has not caused any intrusion of any sort ... it is probably irrational, unreasonable and capricious to bar the press at this point."131 On September 4, 1991, KQED announced that the station would not appeal Judge Schnacke's ruling. ${ }^{132}$

129. Katherine Bishop, Judge Upholds Ban on Videotaping of Executions at San Quentin, N.Y. TIMES, June 8, 1991, at 9.

130. Id.

131. Hager, supra note 124 , at A1.

132. TV Bill Killed, NAT'ı L.J., Sept. 16, 1991, at 6. Although Judge Schnacke's ruling was not appealed, a videotape of Robert Alton Harris' execution was made, pursuant to court order, for the purpose of determining whether California's use of the gas chamber is a "cruel and unusual punishment." Although various news organizations have suggested that the videotape constitutes an official record that must be made available to the public, the Harris videotape is currently being stored in a federal court vault. Philip Hager, Should Tape of Harris Execution Be Released?, L.A. TIMES, May 10, 1992, at A3; William Carlsen \& Harriet Chiang, Harris Death Video Could be Made Public, S.F. ChroN., Apr. 23, 1992, at A1. In an unrelated case, the U.S. Court of Appeals for the Fourth Circuit recently rejected an attempt to videotape an execution for the purpose of assisting in the assertion of a claim that the punishment of electrocution violates the eighth amendment. See Alan Cooper, 4th Circuit Rejects Electrocution Challenge, NAT'L L.J., Feb. 1, 1993, at 7.

The controversial appellate process that resulted in the execution of Robert Alton Harris, which took place early in the morning on April 21, 1992, was recently the subject of a series of essays in The Yale Law Joumal. See Stephen Reinhardt, The Supreme Court, the Death Penalty, and the Harris Case, 102 YALE L.J. 205, 219 (1992); Evan Caminker \& Erwin Chemerinsky, The Lawless Execution of Robert Alton Harris, 102 YALE L.J. 225 (1992); Steven G. Calabresi \& Gary Lawson, Equity and Hierarchy: Reflections on the Harris Execution, 102 YALE L.J. 255, 267 (1992). The UCLA Law Review also recently published a series of articles about the Robert Alton Harris execution. See Daniel E. Lungren \& Mark C. Krotoski, Public Policy Lessons from the Robert Alton Harris Case, 40 UCLA L. REv. 295 (1992); Charles M. Sevilla \& Michael Laurence, Thoughts on the Cause of the Present Discontents: The Death Penalty Case of Robert Alton Harris, 40 UCLA L. REv. 345 (1992). For a first-hand account of the execution of Robert Alton Harris, see Michael Kroll, The Unquiet Death of Robert Harris, UTNE READER, Nov./Dec. 1992, at 92 (reprinted from THE NATion (July 6, 1992)). 


\section{B. State Challenges}

In Halquist v. Department of Corrections, ${ }^{133}$ a journalist asserted that he had the right to attend and videotape an execution based upon several provisions of Washington State's constitution. ${ }^{134}$ Despite the court's finding that films convey substantive information that cannot be conveyed by other forms of media, the Washington Supreme Court rejected the journalist's claim, finding that nothing in the history or the wording of the Washington Constitution provided a "theoretical basis" for the journalist's contentions. Therefore, the court dismissed the journalist's petition against the state officials. ${ }^{135}$

Likewise, although no judicial opinion appears to have been written on the subject, in May 1990 a Virginia judge denied a request by death row inmate Joseph J. Savino for a public execution. ${ }^{136}$ "If you're asking me to make a decision at this level [on a televised execution], I deny such a request," Bedford Circuit Judge William Sweeney told Savino. ${ }^{137}$ Savino, convicted of killing his gay lover, had written a letter to Sweeney asking that his execution be televised. In Savino's words: "I would like to say that since my trial and everything else was public, that my exe-

\section{783 P.2d 1065 (1989) (en banc).}

134. The journalist attempted to ground a right to attend the execution on Wash. Const. art. 1, §30: "The enumeration in this Constitution of certain rights shall not be construed to deny others retained by the people." West's RCWA Const. Art. 1, $\S 30$ (1988), Halquist, 783 P.2d at 1066. However, the court cited a Washington case, State v. Clark, 71 P. 20 (1902), noting that "Clark says nothing about executions, or about whether attendance at an execution is the type of 'fundamental, inalienable [right] under the laws of God and Nature' which is protected under Const. art. 1, § 30." Halquist, 783 P.2d at 1066.

The journalist also sought to find a right to videotape an execution in Wash. Const. art. 1, §5: "Every person may freely speak, write and publish on all subjects, being responsible for the abuse of that right." Id. However, the Washington Supreme Court noted a "substantial difference between the right to publish already acquired information and the right to attend a proceeding for the purpose of news gathering.'" Halquist, 783 P.2d at 1067. In the court's eyes, therefore, it followed that "a taping ban is a limitation on access to substantive information, not a limitation on dissemination." Id.

135. Id. at 1068 (citation omitted). One commentator has noted that the Fifth Circuit's reasoning in Garrett is inconsistent with the reasoning of Halquist. See Tao, supra note 80, at 1045-65 (noting that the Halquist court found execution films to convey substantive information while the Garrett court found that such films were only one form of reporting that could accurately describe an execution).

136. Public Execution Denied, WASH. Post, May 24, 1990, at C4.

137. Id. 
cution be made public.... I I think it should be if it's to be a deterrence to anyone else."138 Another death row inmate's assertion that he had a First Amendment right to have his execution televised was rejected in Florida because of procedural deficiencies. ${ }^{139}$

\section{Freedom of the Press Jurisprudence}

The Supreme Court has decided several cases which address the scope of the rights of the press in a democratic society. For purposes of delineating the press' right to televise executions, this section discusses case law in three arguably analogous areas: (1) access to trials, (2) cameras in the courtroom, and (3) access to prisons. The constitutional basis for finding a right to televise executions is the subject of Section VII of this Article.

\section{A. Access to Trials}

In Richmond Newspapers, Inc. v. Commonwealth of Virginia, ${ }^{140}$ the defendant's attorney in a criminal prosecution for murder made a pre-trial motion requesting that the proceedings be closed to the public. ${ }^{141}$ When the prosecutor offered no objection, the court summarily ruled " 'that the Courtroom be kept clear of all parties except the witnesses when they testify." "142 Later in the day, however, Richmond Newspapers sought a hearing on a motion to vacate the closure order, and the trial judge granted the request. At that hearing, Richmond Newspapers argued that no evidentiary findings had been made by the court prior to the closure order and that the court had failed to consider any less drastic measures to protect the defendant's right to a fair trial. ${ }^{143}$ Despite these considerations, the trial

138. Id.

139. Ferguson v. State, 417 So. $2 d 631,635-36$ (Fla. 1982). For an argument that private execution statutes deprive death row inmates of their First Amendment rights, see Roderick C. Patrick, Note, Hiding Death, 18 NEw ENG. J. ON CRIM. \& CIV. CONFINEMENT 117 (1992).

140. 448 U.S. 555 (1980).

141. Id. at 559. From a procedural standpoint, before defense counsel requested that the proceedings be closed to the public, the defendant in Richmond Newspapers was about to be tried for the fourth time. The previous trials had resulted in a conviction reversed on appeal and two mistrials. $I d$.

142. Id. at 560 (quoting Transcript of Sept. 11, 1978 Hearing on Defendant's Motion to Close Trial to the Public 4-5).

143. Id. at 560 . 
court sided with the defendant and ordered the trial to continue the following day " 'with the press and public excluded." "144

In what was hailed as "a watershed case" by Justice Stevens, ${ }^{145}$ the United States Supreme Court reversed the trial court in Richmond Newspapers. Specifically, the Court held that a state trial judge's order closing a murder trial from public access, at the request of the accused, violated the First and Fourteenth Amendments. However, of the seven Justices who recognized a constitutional right of access in Richmond Newspapers, six arrived at their decisions through separate opinions. Justice Powell took no part in the case, leaving Justice Rehnquist as the sole dissenter.

An opinion written by Chief Justice Burger, in which Justices White and Stevens joined, announced the judgment of the Court in Richmond Newspapers. To begin his analysis, Burger distinguished the case of Gannett Co. v. DePasquale, ${ }^{146}$ which held that members of the press have no "enforceable right of access to a pretrial suppression hearing." 147 Then, tracing the history of trials back to the days before the Norman Conquest, ${ }^{148}$ Burger concluded that "the historical evidence demonstrates conclusively that at the time when our organic laws were adopted, criminal trials both here and in England had long been presumptively open." 149 Burger further emphasized the "significant community therapeutic value"1so and the "prophylactic purpose"151 of open trials. "The crucial prophylactic aspects of the administration of justice cannot function in the dark; no community catharsis can occur if justice is 'done in a corner [or] in any covert manner.' "152

144. Id. at 561 (quoting Transcript of Sept. 11, 1978 Hearing on Defendant's Motion to Vacate 27).

145. Id. at 582 (Stevens, J., concurring).

146. 443 U.S. 368 (1979).

147. Richmond Newspapers, 448 U.S. at 564 (emphasis in original).

148. Id. at 565 .

149. Id. at 569 .

150. Id. at 570 .

151. Id. at 571 .

152. Id. (quoting 1677 Concessions and Agreements of West New Jersey, reprinted in Sources OF OUR Liberties 184, 188 (R. Perry ed., 1959)). Chief Justice Burger also noted that "[p]eople in an open society do not demand infallibility from their institutions, but it is difficult for them to accept what they are prohibited from observing." Id. at 572. 
In his concurring opinion, Justice Stevens noted that, "for the first time, the Court unequivocally holds that an arbitrary interference with access to important information is an abridgment of the freedoms of speech and of the press ...."153 Thus, Justice Stevens concluded that the record disclosed no justification for the closure order, and that, therefore, the order violated the First Amendment. ${ }^{154}$ Justice White concurred with Chief Justice Burger on the First Amendment issue, noting the case could have been avoided if Gannett had construed the Sixth Amendment "to forbid excluding the public from criminal proceedings except in narrowly defined circumstances."155

In sharp contrast, Justice Brennan's concurrence in Richmond Newspapers would have given the First Amendment a "structural role to play in securing and fostering our republican system of self-government."156 According to one commentator, this view of the First Amendment would "protect the free discourse necessary for self-government."157 In Brennan's words: "Implicit in this structural role is not only 'the principle that debate on public issues should be uninhibited, robust, and wideopen,' but also the antecedent assumption that valuable public debate - as well as other civic behavior - must be informed."158 However, because Justice Brennan's approach would have made a constitutional right of access "theoretically endless," he proposed two limitations on that right. ${ }^{159}$ First, "the case for a right of access has special force when drawn from an enduring and vital tradition of public entree to particular proceedings or information."160 Second, press coverage must serve the purposes of the particular governmental proceeding. ${ }^{161}$

153. Id. at 583 (Stevens, J., concurring).

154. Id. at 584 .

155. Id. at 582 (White, J., concurring).

156. Id. at 587 (Brennan, J., concurring) (emphasis in original).

157. Mamantov, supra note 9 , at 386.

158. Richmond Newspapers, Inc. v. Virginia, 448 U.S. 550, 587 (1980) (Brennan, J., concurring) (citation omitted) (quoting New York Times Co. v. Sullivan, 376 U.S. 254, 270 (1964)). According to Justice Brennan: "[P]ublic access to court proceedings is one of the numerous 'checks and balances' of our system, because 'contemporaneous review in the forum of public opinion is an effective restraint on possible abuse of judicial power . . . . " Id. at 592 (quoting In re Oliver, 333 U.S. 257, 270 (1948)).

159. Mamantov, supra note 9, at 386.

160. Richmond Newspapers, 448 U.S. at 589 (citation omitted).

161. Id. at 589, 593-97. 
The two other opinions in Richmond Newspapers were written by Justice Stewart and Justice Rehnquist. Concurring, Stewart remained convinced that the right to a public trial should be rooted in the Sixth Amendment, ${ }^{162}$ but he was "driven to conclude, as a secondary position, that the First Amendment must provide some measure of protection for public access to the trial." 163 Justice Rehnquist, in dissent, reframed the issue; instead of focusing on the freedom of the press to override the defendant's right to a fair trial, he asked whether any provision in the Constitution could prohibit what the Virginia judge did in Richmond Newspapers. Rehnquist concluded that no such prohibition could be found. ${ }^{164}$

\section{B. Cameras in the Courtroom}

Among legal commentators, the question of whether trials should be televised has drawn considerable debate. ${ }^{165}$ As one commentator has pointed out, in the context of televised coverage, "the issue of the proper balance between rights of a free press and the right to a fair trial implicates the first, fifth, sixth, and fourteenth amendments to the United States Constitution."166 While the United States Supreme Court has never squarely addressed the issue of whether absolutely denying the press televised access to trials is consistent with the First Amendment, ${ }^{167}$ the Supreme Court has handed down two cases related to the issue of televised coverage of trials.

The Supreme Court first considered the implications of televised coverage of trials in Estes v. Texas. ${ }^{168}$ In that case, Billy Sol Estes, a much-publicized financier, was convicted of swin-

162. Id. at 603 (Stewart, J., concurring).

163. Id. at 604 .

164. Id. at 606 (Rehnquist, J., dissenting).

165. Richard H. Frank, Cameras in the Courtroom: A First Amendment Right of Access, 9 CoMm/ENT L.J. 749, 752 \& n.15 (1987).

166. Id. at 752 (footnotes omitted).

167. Several lower courts have concluded that television access to trials can be absolutely denied consistently with the first amendment. See, e.g., United States v. Hastings, 695 F.2d 1278 (11th Cir.), reh'g en banc denied per curiam, 704 F.2d 559, cert. denied, 459 U.S. 1203 (1983); Westmoreland v. Columbia Broadcasting System, Inc., 752 F.2d 16 (2d Cir. 1984), cert. denied, 472 U.S. 1017 (1985); United States v. Edwards, 785 F.2d 1293 (5th Cir. 1986). For a discussion of these cases, see Frank, supra note 165 , at $765-772$.

168. 381 U.S. 532 (1965). 
dling after a trial of great notoriety which was broadcast on television over Estes' objection. ${ }^{169}$ In narrowly reversing Estes' conviction, the Supreme Court held that the television coverage of Estes' trial deprived him of his due process rights under the Fourteenth Amendment. ${ }^{170}$ While Justice Harlan's swing vote in Estes remains controversial among commentators, ${ }^{171}$ a majority of the Court in Estes emphasized the disruptive nature of the television coverage in reversing Estes' conviction. ${ }^{172}$ In reaching this narrow decision, the Court emphasized: "When the advances in these arts permit reporting by printing press or by television without their present hazards to a fair trial we will have another case."173

In 1981, the Supreme Court again considered the implications of electronic coverage in deciding Chandler v. Florida. ${ }^{174}$ In that case, the Court stated that television coverage of trials is not per se unconstitutional. ${ }^{175}$ Indeed, "[a]bsent a showing of prejudice" to the defendants in Chandler, the Court was unwilling to invalidate Florida's rule allowing television coverage of

169. Id. at 535-38.

170. Id. at 535 .

171. According to one commentator, Justice Harlan's opinion in Estes has been interpreted as: (1) "erecting a per se ban on television coverage of trial proceedings in accord with the opinions of Clark and Warren;" (2) "limiting the application of the Court's prohibition to notorious trials;" and (3) "limiting the application of the Court's prohibition to the facts of the Estes case." Frank, supra note 165, at 758 (footnotes omitted). The third view, which has "emerged as the Supreme Court's position," id. at $758 \mathrm{n} .48$ (citations omitted), is supported by language from Justice Harlan's statement: "At the present juncture I can only conclude that televised trials, at least in cases like this one, possess such capabilities for interfering with the even course of the judicial process that they are constitutionally banned." Estes, 381 U.S. at 596 (Harlan, J., concurring) (emphasis added).

172. In describing the atmosphere created by coverage of the pre-trial hearings, Justice Clark wrote:

The videotapes of these hearings clearly illustrate that the picture presented was not one of that judicial serenity and calm to which petitioner was entitled .... Indeed, at least 12 cameramen were engaged in the courtroom throughout the hearing taking motion and still pictures and televising the proceedings. Cables and wires were snaked across the courtroom floor, three microphones were on the judge's bench and others were beamed at the jury box and the counsel table.

Estes, 381 U.S. at 536 (citations omitted); see also id. at 552-53, 586 app. (Warren, C.J., concurring) (discussing the conduct of reporters in the courtroom with photographs as an appendix).

173. Estes, 381 U.S. at 540.

174. 449 U.S. 560 (1981).

175. Id. at 582 . 
trials. ${ }^{176}$ Thus, the Chandler majority limited the holding of Estes to those trials " 'utterly corrupted' by press coverage."177

\section{Prison Access}

In 1974, the United States Supreme Court decided the companion cases of Pell v. Procunier ${ }^{178}$ and Saxbe v. Washington Post Co. ${ }^{179}$ In Pell, several prison inmates and journalists brought suit challenging section 415.071 of the California Department of Corrections Manual, which provided that " '[p]ress and other media interviews with specific individual inmates will not be permitted." "180 Focusing initially on the proposition that " "[1]awful incarceration brings about the necessary withdrawal or limitation of many privileges and rights," "181 the Court concluded that security considerations were important enough to justify the imposition of some restrictions regarding face-to-face interviews with inmates. ${ }^{182}$ "So long as reasonable and effective means of communication remain open and no discrimination in terms of content is involved ... 'prison officials must be accorded latitude." "183 Recognizing that there "'may be particular qualities inherent in sustained, face-to-face debate, discussion and questioning," "184 the Court went on to conclude that written communication between the media and the inmates, and communication through inmates' families, friends, clergy, and attorneys affords inmates a "substantially unimpeded channel

176. Id.

177. Id. at 573 n.8 (quoting Murphy v. Florida, 421 U.S. 794, 798 (1975)). In particular, the Court concluded that Estes "is not to be read as announcing a constitutional rule barring still photographic, radio, and television coverage in all cases and under all circumstances." Id. at 573.

178. 417 U.S. 817 (1974).

179. 417 U.S. 843 (1974).

180. Pell, 417 U.S. at 819.

181. Id. at 822 (quoting Price v. Johnston, 334 U.S. 266 (1948)). "In the First Amendment context a corollary of this principle is that a prison inmate retains those First Amendment rights that are not inconsistent with his status as a prisoner or with the legitimate penological objectives of the corrections system." Id.

182. Id. at 827 .

183. Id. at 826 (emphasis added) (quoting Cruz v. Beto, 405 U.S. 319, 321 (1972)). According to Justice Stewart: "[I]n light of the alternative channels of communication that are open to prison inmates, we cannot say on the record in this case that this restriction on one manner [of communication] is unconstitutional." Id. at 827-28 (emphasis added) (footnote omitted).

184. Id. at 823 (quoting Kleindienst v. Mandel, 408 U.S. 753, 765 (1972)). 
for communication with ... representatives of the news media."185 Ultimately, the Court in Pell held that "the Constitution does not ... require government to accord the press special access to information not shared by members of the public generally." 186

In Saxbe, the Supreme Court also held that the press has no more right of access to information than does the public generally. In Saxbe, a major metropolitan newspaper challenged the constitutionality of one of the policies of the Federal Bureau of Prisons. The regulation in question prohibited any personal interviews between reporters and individually designated prison inmates. ${ }^{187}$ In an opinion written by Justice Stewart, the Court noted that the policy under consideration was similar to the one in Pell, ${ }^{188}$ and that the "visitation policy does not place the press in any less advantageous position than the public generally." 189 Indeed, the Court noted that the Bureau of Prisons' policy provided journalists more access than that afforded the public generally in that the policy permitted the press to tour the prisons and to photograph prison facilities, and to conduct brief interviews with inmates encountered during such tours. ${ }^{190}$

In another case decided by the Supreme Court, Houchins v. $K Q E D$, Inc., ${ }^{191}$ two branches of the National Association for the Advancement of Colored People (NAACP) and a broadcasting company, KQED, filed a complaint for injunctive relief after KQED was denied permission to inspect and take photographs in a portion of a county jail where a prisoner had committed suicide and where prison conditions were allegedly responsible for the prisoner's problems. The complaint alleged that the county sheriff had violated the First Amendment by refusing to permit media access and by failing to provide any effective means by which the public could be informed of the conditions prevailing at the county jail or learn of the prisoners' griev-

185. Id. at 824-25. However, the Court was quick to note that this was not "an attempt by the State to conceal the conditions in its prisons or to frustrate the press' investigation and reporting of those conditions." Id. at 830 .

186. Id. at 834 (footnote omitted).

187. Saxbe v. Washington Post Co., 417 U.S. 843, 844 (1974).

188. Id. at 846 .

189. Id. at 849 .

190. Id. at 847 .

191. 438 U.S. 1 (1978). 
ances. ${ }^{192}$ The plaintiffs asserted that public access was essential for NAACP members to participate in the public debate regarding jail conditions in the county jail. The plaintiffs further asserted that television coverage of the conditions in the cells and facilities was the most effective way of informing the public of prison conditions. ${ }^{193}$

After considering the evidence, the district court preliminarily enjoined the county sheriff from denying KQED news personnel and "responsible representatives" of the news media access to the prison facilities and from preventing such persons from utilizing photographic and sound equipment. In particular, the district court found that testimony of officials involved with other prison facilities indicated that a "more flexible press policy" at the county jail was both "desirable and attainable."194

On interlocutory appeal from the district court's order, the county sheriff invoked the Supreme Court's decision in Pell, arguing that the district court had abused its discretion by ordering the county sheriff to give the media greater access to the jail than he gave to the general public. Albeit in three separate opinions, the United States Court of Appeals for the Ninth Circuit upheld the district court's injunction, holding as follows: "Pell v. Procunier does not stand for the proposition that the correlative constitutional rights of the public and the news media to visit a prison must be implemented identically. The access needs of the news media and the public differ."195

On appeal to the United States Supreme Court, the question presented was whether the news media has a constitutional right of access to a county jail, over and above that of other persons, to interview inmates and make sound recordings, films, and photographs for publication and broadcasting by newspapers, radio, and television. ${ }^{196}$ In a four to three decision, a three-member plurality reversed the decision of the Ninth Circuit, holding that under Pell and Saxbe, the media has no special right of access different from that of the general public. ${ }^{197}$ According to Chief

192. Id. at 3-4.

193. Id. at 4 .

194. Id. at 6-7.

195. KQED, Inc. v. Houchins, 546 F.2d 284, 286 (9th Cir. 1976), rev'd, 438 U.S. 1 (1978).

196. Houchins, 438 U.S. at 3.

197. Id. at 15-16. 
Justice Burger's plurality opinion: "The public importance of conditions in penal facilities and the media's role of providing information afford no basis for reading into the Constitution a right of the public or the media to enter these institutions, with camera equipment, and take moving and still pictures of inmates for broadcast purposes." 198

However, in a decisive concurring opinion, Justice Stewart held that "KQED was entitled to injunctive relief of more limited scope."199 Therefore, under the Supreme Court's "narrowest concurrence" rule, it has been asserted that Justice Stewart's opinion can, arguably, be viewed as binding precedent. ${ }^{200}$ In his concurrence, Justice Stewart held that the district court's injunction was overbroad because it gave the press access to areas and sources of information from which persons on the public tours had been excluded. ${ }^{201}$ Although Justice Stewart agreed with Chief Justice Burger that the injunction issued by the district court was overbroad, he disagreed with the plurality opinion as to how the abstract principles set forth in Pell and Saxbe should be applied to the facts of the case. In particular, whereas Justice Stewart felt that "the concept of equal access must be accorded more flexibility in order to accommodate the practical distinc-

198. Id. at 9. Despite this holding, Chief Justice Burger's opinion recognized the media's role as the "eyes and ears" of the public. Id. at 8.

199. Id. at 16 (Stewart, J., concurring).

200. Philbin, supra note 57, at 147 \& n. 95; see Plaintiff's Trial Brief at $8 \mathrm{n.8}$, KQED, Inc. v. Vasquez, 18 Media L. Rep. (BNA) 2323 (N.D. Cal. 1991) No. C901383RHS:

Given the division of the Court members, Justice Stewart's opinion governs: it is the "least common denominator" of the Court's decision. It has long been the rule that "[w]hen a fragmented Court decides a case and no single rationale explaining the result enjoys the assent of five justices, 'the holding of the Court may be viewed as that position taken by those Members who concurred in the judgments on the narrowest grounds." "

Id. (citing, among other cases, Marks v. United States, 430 U.S. 188, 193 (1977)); see also LAURENCE Tribe, American Constitutional LAw $\S 16-22$, at 1529-30 \& n.33 (2d ed. 1988).

201. Houchins, 438 U.S. at 18 (Stewart, J., concurring):

In two respects ... the District Court's preliminary injunction was overbroad. It ordered the Sheriff to permit reporters into the [prison] facility and it required him to let them interview randomly encountered inmates. In both these respects, the injunction gave the press access to areas and sources of information from which persons on the public tours had been excluded, and thus enlarged the scope of what the Sheriff and Supervisors had opened to public view. 
tions between the press and the general public,"202 Chief Justice Burger's plurality opinion viewed "equal access" as meaning access that is identical in all respects.

In addition, Justice Stewart emphasized the critical role that the press plays in a democratic society. According to Justice Stewart:

When on assignment, a journalist does not tour a jail simply for his own edification. He is there to gather information to be passed on to others, and his mission is protected by the Constitution for very specific reasons. "Enlightened choice by an informed citizenry is the basic ideal upon which an open society is premised ...." Our society depends heavily on the press for that enlightenment. Though not without its lapses, the press "has been a mighty catalyst in awakening public interest in governmental affairs, exposing corruption among public officers and employees and generally informing the citizenry of public events and occurrences.

That the First Amendment speaks separately of freedom of speech and freedom of the press is no constitutional accident, but an acknowledgment of the critical role played by the press in American society. The Constitution requires sensitivity to that role, and to the special needs of the press in performing it effectively. A person touring Santa Rita jail can grasp its reality with his own eyes and ears. But if a television reporter is to convey the jail's sights and sounds to those who cannot personally visit the place, he must use cameras and sound equipment. In short, terms of access that are reasonably imposed on individual members of the public may, if they impede effective reporting without sufficient justification, be unreasonable as applied to journalists who are there to convey to the general public what the visitors see. ${ }^{203}$

Subsequently, noting that he "would not foreclose the possibility of further relief for KQED on remand,"204 Justice Stewart stated that the First and Fourteenth Amendments required the county sheriff "to give members of the press effective access to the same areas" that the general public could already visit. ${ }^{205}$ In practical terms, Justice Stewart approved of the district court's finding that "the media required cameras and recording equipment for effective presentation to the viewing public of the conditions at

202. Id. at 16.

203. Id. at 17 (citations omitted). Justice Stewart's concurring opinion is consistent with his belief that the press serves as a "Fourth Estate," whose function is to criticize and question the three official branches of government. See Potter Stewart, Or of the Press, 26 Hastings L.J. 631, 633-34 (1975).

204. Houchins, 438 U.S. at 18.

205. Id. at 17 (emphasis in original). 
the jail seen by individual visitors, and that their use could be kept consistent with institutional needs."206 Indeed, Justice Stewart stated that this element of the district court's order was "both sanctioned by the Constitution and amply supported by the record." 207 On remand, the district court implemented Justice Stewart's proposal; KQED was allowed to use "cameras and recording equipment for effective presentation to the viewing public ....."208

\section{The Use of History in Constitutional Analysis}

While the debate between originalists and nonoriginalists continues, ${ }^{209}$ the United States Supreme Court undeniably adopts an historical approach in resolving many constitutional issues. Therefore, having already examined the history of public executions, ${ }^{210}$ this Article will examine how the modern Court has used an historical framework in previous cases to resolve other constitutional issues. Arguing by analogy, this Article ultimately concludes that an historical approach, when coupled with First and Eighth Amendment principles, mandates that private execution laws must be declared unconstitutional.

\section{A. Death Penalty Cases}

The United States Supreme Court has repeatedly used an historical framework to analyze death penalty issues. In Furman v. Georgia ${ }^{211}$ and in Gregg v. Georgia, ${ }^{212}$ for example, members of the Supreme Court reviewed the history of the Eighth Amendment's prohibition of "cruel and unusual" punishments. ${ }^{213}$ Noting that the phrase first appeared in the English Bill of Rights of $1689,{ }^{214}$ the Court emphasized that "capital

206. Id. at 18 .

207. Id.

208. Philbin, supra note 57, at 148 (citing Plaintiffs Trial Brief at 9, 10 n.9, KQED, Inc. v. Vasquez, 18 MEDIA L. REP. (BNA) 2323 (N.D.' Cal. 1991) (No. C901383RHS)).

209. Compare Raoul Berger, Original Intent and Boris Bittker, 66 IND. L.J. 723 (1991) with Boris I. Bittker, Observations on Raoul Berger's 'Original Intent and Boris Bittker," 66 IND. L.J. 757 (1991).

210. See supra Section II.

211. 408 U.S. 238 (1972).

212. 428 U.S. 153 (1976).

213. See, e.g., Furman, 408 U.S. at 316-28 (Marshall, J., concurring).

214. Gregg, 428 U.S. at 169. 
punishment was accepted by the Framers."215 As the Court stressed in Gregg: "At the time the Eighth Amendment was ratified, capital punishment was a common sanction in every state."216

An historical approach has also been utilized in tangential areas of death penalty litigation. For instance, in Stanford $v$. Kentucky, ${ }^{217}$ the Court concluded that sentencing sixteen and seventeen-year-old offenders to death did not violate the "evolving standards of decency that mark the progress of a maturing society."218 However, before even reaching this issue, the Court underscored that "[n]either petitioner asserts that his sentence constitutes one of 'those modes or acts of punishment that had been considered cruel and unusual at the time that the Bill of Rights was adopted.'

\section{B. Right of Access Cases}

1. Trials

In Richmond Newspapers, Inc. v. Commonwealth of Virginia, ${ }^{220}$ the Anglo-American tradition of open trials was mentioned repeatedly throughout the Justices' opinions. ${ }^{221}$ For

215. Id. at 177 .

216. Id.

217. 492 U.S. 361 (1989).

218. Id. at 364-80.

219. Id. at 368 (quoting Ford v. Wainwright, 477 U.S. 399, 405 (1986)). The Stanford Court noted that, even if the petitioners had asserted such a claim, they could not have supported their contention. In support of the Court's conclusion, Justice Scalia stated that, at the time the Bill of Rights was enacted, the common law set the rebuttable presumption of incapacity to commit a felony at age 14 and that capital punishment was theoretically possible for anyone over the age of seven. The Court further emphasized that, in accordance with this common law tradition, at least 281 offenders under the age of 18 had been executed in the United States. Id. (citations omitted).

220. 448 U.S. 555 (1980).

221. Chief Justice Burger's opinion, joined by Justices White and Stevens, contained several references to history. See, e.g., id. at 564 ("The origins of the proceeding which has become the modern criminal trial in Anglo-American justice can be traced back beyond reliable historical records."); id. at 569 ("[T]he historical evidence demonstrates conclusively that at the time when our organic laws were adopted, criminal trials both here and in England had long been presumptively open.").

Several of the concurring opinions in Richmond Newspapers also stressed the importance of history in finding a constitutional right of access. See, e.g., id. at 590 (Brennan, J., concurring) ("This legacy of open justice was inherited by the English settlers in America. The earliest charters of colonial government expressly perpetuated the accepted practice of public trials."); id. at 599 (Stewart, J., concurring) ("[I]t 
example, in Chief Justice Burger's opinion, the history of open trials was traced back to "the days before the Norman Conquest,"222 with Burger citing such notables as Bentham, ${ }^{223}$ Blackstone, ${ }^{224}$ Pollock $^{225}$ and Coke. ${ }^{226}$ Complimenting this approach, Justice Blackmun's concurring opinion described the Court's return to history as "a welcome change in direction,"227 while Justice Brennan's concurring opinion emphasized the importance of "consult[ing] historical and current practice with respect to open trials." ${ }^{228}$

Despite the overwhelming Anglo-American tradition of public trials, in Richmond Newspapers, the State of Virginia argued that neither the Constitution nor the Bill of Rights contains any specific provision protecting the public's right to attend criminal trials. ${ }^{229}$ Announcing the Court's judgment, Chief Justice Burger responded to this contention: "Standing alone, this is correct, but there remains the question whether, absent an explicit provision, the Constitution affords protection against exclusion of the public from criminal trials."230 Concluding that "the right to attend criminal trials is implicit in the guarantees of the First Amendment,"231 Chief Justice Burger noted that "the Court has acknowledged that certain unarticulated rights are implicit in enumerated guarantees."232

\section{Cameras in the Courtroom}

Because cameras were introduced in the courtroom only re-

has for centuries been a basic presupposition of the Anglo-American legal system that trials shall be public trials."); id. at 601 (Blackmun, J., concurring) ("It is gratifying ... to see the Court now looking to and relying upon legal history in determining the fundamental public character of the criminal trial.") (citation omitted).

222. Id. at 565 .

223. Id. at 569 .

224. Id.

225. Id. at 565-66.

226. Id. at 565 .

227. Id. at 601 (Blackmun, J., concurring).

228. Id. at 589 (Brennan, J., concurring).

229. Id. at 575 .

230. Id.

231. Id. at 580 (footnote omitted).

232. Id. at 579. Burger listed as such "unarticulated rights" the rights of association and privacy, the right to be presumed innocent, the right to be judged by a standard of proof beyond a reasonable doubt in a criminal case, and the right to travel. Id. at $579-80$. 
cently, ${ }^{233}$ the Supreme Court has had little opportunity to draw upon history in handing down its constitutional decisions in this area. However, the Court has not been completely silent on this matter. For example, in Estes v. Texas, ${ }^{234}$ the Court noted the traditional Anglo-American distrust for secret trials. ${ }^{235}$ Starting with the proposition that the Sixth Amendment guarantees the accused a "public trial," the Court stated that "[h]istory had proven that secret tribunals were effective instruments of oppression."236

Furthermore, since Estes, the Supreme Court has grown more tolerant of television's use in judicial proceedings. Most notably, the Court backed away from Estes' rigid approach in Chandler v. Florida, ${ }^{237}$ with at least two Justices in Chandler suggesting that Estes be overruled. ${ }^{238}$ Indeed, in tracking the technological advances in television since Estes, the Chandler majority emphasized that "many of the negative factors found in Estes-cumbersome equipment, cables, distracting lighting, numerous technicians-are less substantial factors today than they were at that time."239

\section{Prisons}

The cases of Pell v. Procunier ${ }^{240}$ and Saxbe v. Washington Post Co. ${ }^{241}$ contain little mention of history. In Pell, although the legal issues were fiercely debated, none of the three opinions

233. According to one commentator, the first televised trial took place in Oklahoma City in 1953. Frank, supra note 165 , at $756 \&$ n.33.

234. 381 U.S. 532 (1965).

235. Id. at 539 (citing In re Oliver, 333 U.S. 257, 268-70 (1948)).

236. Id. at 538-39.

237. 449 U.S. 560 (1981).

238. Id. at 583 (Stewart, J., concurring) (" $[R]$ ather than join what seems to me a wholly unsuccessful effort to distinguish [Estes], I would now flatly overrule it."); id. at 586-87 (White, J., concurring) ("For the reasons stated by Justice Stewart in his concurrence today, I think Estes is fairly read as establishing a per se constitutional rule against televising any criminal trial if the defendant objects. So understood, Estes must be overruled to affirm the judgment below.").

239. Id. at 576. Indeed, in Estes, Justice Harlan foreshadowed the Court's holding in Chandler. Estes, 381 U.S. at 595 ("[T]he day may come when television will have become so commonplace an affair in the daily life of the average person as to dissipate all reasonable likelihood that its use in courtrooms may disparage the judicial process.").

240. 417 U.S. 817 (1974).

241. 417 U.S. 843 (1974). 
in the case mentioned the history of prison visitation rights. Writing for the majority, Justice Stewart was content in stating that it is a "familiar proposition" that incarceration compels " "the necessary withdrawal or limitation of many privileges and rights, a retraction justified by the considerations underlying our penal system." "242 In $S a x b e$, visitation rights again received no attention, with Justice Powell merely noting in dissent that "[t]he history of our prisons is in large measure a chronicle of public indifference and neglect." 243

In Richmond Newspapers, Inc. v. Commonwealth of Virginia, the Supreme Court distinguished the Pell and Saxbe cases on the grounds that those cases "were concerned with penal institutions which, by definition, are not 'open' or public places."244 According to the Court, "Penal institutions do not share the long tradition of openness, although traditionally there have been visiting committees of citizens, and there is no doubt that legislative committees could exercise plenary oversight and "visitation rights." "245

\section{Constitutionality OF TeleVised Executions}

As noted by judges and commentators, private execution statutes raise several constitutional issues. First, current statutory schemes raise First Amendment concerns, including the application of right of access, content regulation and prior restraint jurisprudence. Second, from a radio or television reporter's perspective, because some private execution statutes arguably favor print journalists over broadcast journalists, such statutes can implicate Equal Protection concerns. Finally, from an inmate's perspective, right of privacy issues also could arise if a state authorized a televised execution.

Highlighting each of these constitutional concerns, this Article will discuss the constitutionality of the private execution statutes currently in effect. Although this Article concludes that

242. Pell, 417 U.S. at 822 (quoting Price v. Johnston, 334 U.S. 266, 285 (1948)).

243. Saxbe, 417 U.S. at 861 n.7 (Powell, J., dissenting).

244. Richmond Newspapers, Inc. v. Virginia, 448 U.S. 550, 576 n.11 (1980).

245. Id. The U.S. Supreme Court has noted that "[t]he early penal reform movements in this country and England gained impetus as a result of reports from citizens and visiting committees who volunteered or received commissions to visit penal institutions and make reports." Houchins v. KQED, Inc., 438 U.S. 1, 12-13 (1978). 
private execution statutes are unconstitutional, this Article finds that it is the history of public executions - coupled with the application of First Amendment principles and the jurisprudence of Trop v. Dulles ${ }^{246}$ - that requires the Supreme Court to invalidate private execution statutes.

\section{A. First Amendment Analysis \\ 1. Prior Restraint}

The prior restraint doctrine probably originated as an attempt to prohibit the practice of sixteenth and seventeenth century English licensing systems under which all printers were required to gain the approval of state or church officials before publishing books or pamphlets. ${ }^{247}$ The doctrine was first invoked by the Supreme Court in Near v. Minnesota, ${ }^{248}$ in which a state scheme for abating scandalous or defamatory newspapers was held unconstitutional. ${ }^{249}$ In general, the prior restraint doctrine concerns governmental actions prohibiting the publication of previously obtained information. ${ }^{250}$ The Supreme Court's preference for subsequent sanctions was best articulated by Chief Justice Burger in Nebraska Press Association v. Stuart:"251 "A prior restraint . . . has an immediate and irreversible sanction. If it can be said that a threat of criminal or civil sanctions after publication 'chills' speech, prior restraint 'freezes' it at least for the time."252

On the issue of public executions, the Fifth Circuit Court of

246. 356 U.S. 86 (1958).

247. See Near v. Minnesota, 283 U.S. 697, 713 (1931); Geoffrey R. STONE, Louis M. Seidman, Cass R. Sunstein \& Mark D. Tushnet, Constitutional LAW 1131 (2d ed. 1991); TRIBE, supra note 200, § 12-34. See generally Thomas I. Emerson, The Doctrine of Prior Restraint, 20 LAW \& CoNTEMP. Problems 648 (1955); William T. Mayton, Toward a Theory of First Amendment Process: Injunctions of Speech, Subsequent Punishment, and the Costs of the Prior Restraint Doctrine, 67 CORNELL L. REV. 245, 247.49 (1982).

248. 283 U.S. 697 (1931).

249. Id. For a discussion of Near, see Vincent Blasi, Toward a Theory of Prior Restraint: The Central Linkage, 66 MiNN. L. REv. 11, 15-19 (1981).

250. See Nebraska Press Ass'n v. Stuart, 427 U.S. 539, 556 (1976) (the first amendment provides "special protection against orders that prohibit the publication or broadcast of particular information or commentary-orders that impose a 'previous' or "prior' restraint").

251. 427 U.S. 539 (1976).

252. Id. at 559 . 


\section{Appeals in Garrett v. Estelle ${ }^{253}$ rejected a prior restraint argu-} ment in one terse paragraph:

[A]micus suggests that the proposed simultaneous closed circuit telecast is a "publication" and that to prohibit its use in any way, such as by filming, is an illegal prior restraint on republication. This suggestion is similar to the argument made by Garrett that once he is given access to information by the government, here by closed circuit telecast, the government may not limit the use Garrett may make of the information, such as filming it. But the access granted to Garrett and the other members of the press is limited. Access for the purpose of filming is not provided, and the first amendment does not require that it be provided. ${ }^{254}$

However, at least one commentator has argued that the prior restraint doctrine is applicable in the context of public executions:

[T]o say that prior restraint is eschewed only with respect to publication of news, but not to news gathering, is to ignore that the latter in most cases precedes the former, and that in cases like Garrett both are content-related. It takes little imagination to understand that, as long as the objective is to suppress publication because of its content, there is little difference between situations in which the government first allows the cameraman to film the event and then takes his film away, and those in which the government merely prevents him from filming altogether; the result is the same and only the means have been changed. ${ }^{255}$

Despite this poignant attempt to apply the prior restraint doctrine to restrictions on the filming of executions, this argument stretches the doctrine too far. Although the prior restraint doctrine has been used to eliminate numerous types of government censorship, ${ }^{256}$ the doctrine has never embraced newsgathering. ${ }^{257}$ In Pell v. Procunier, ${ }^{258}$ for example, the Supreme

253. 556 F.2d 1274 (5th Cir. 1977).

254. Id. at 1279.

255. Comment, supra note 80 , at 749 (footnotes omitted) (emphasis in original).

256. The prior restraint doctrine has been applied "to void procedurally inadequate schemes of government censorship of films, books, and plays; to strike down overbroad permit requirements; and to invalidate discriminatory taxes on the press." TrIBE, supra note 200, $\S 12-34$, at 1039-40 (footnotes omitted).

257. See Emerson, supra note 247, at $655-56$ (listing four types of prior restraints, none of which includes newsgathering activities); see also Paul G. Cassell, Restrictions on Press Coverage of Military Operations: The Right of Access, Grenada, and "Off-theRecord Wars," 73 GEO. L.J. 931,949 (1985) ("Prior restraint analysis is not particularly helpful ... in considering whether the Constitution requires press access to military operations."). As Cassell argues in the context of military operations, "[d]enying the press access to military operations ... does not forbid the publication of any 


\section{Court stated:}

It is one thing to say ... that government cannot restrain the publication of news emanating from [certain] sources. . . . It is quite another thing to suggest that the Constitution imposes upon government the affirmative duty to make available to journalists sources of information not available to members of the public generally. ${ }^{259}$

Likewise, in Gannett Co. v. DePasquale, ${ }^{260}$ the Supreme Court held that where a pretrial exclusion order did not prevent the press "from publishing any information in its possession," the proper inquiry was whether the press has been denied any constitutional right of access. ${ }^{261}$ Thus, because the prior restraint doctrine only prohibits the government from suppressing information already in the hands of journalists and private parties, the prior restraint doctrine is not an effective tool with which to attack private execution statutes.

\section{Content Regulation}

With its roots in the 1930 s and 1940 s, the "content distinction" in First Amendment jurisprudence has emerged as a fixture in determining the appropriate level of scrutiny for laws regulating speech. ${ }^{262}$ "Content-based" restrictions limit expression based on the message they convey. Examples of such restrictions are laws that prohibit seditious libel, ban the publication of confidential information, or outlaw the display of swastikas in certain neighborhoods. "Content-neutral" restrictions limit communication without regard to the content or communicative impact of the message conveyed. Laws that prohibit noisy speeches near hospitals, ban billboards in residential communities, or forbid the distribution of pamphlets in public

information; rather it prevents the press and the public from obtaining information." Id. at 950 (footnote omitted).

258. 417 U.S. 817 (1974).

259. Id. at 834 .

260. 443 U.S. 368 (1979).

261. Id. at 393 n.25.

262. See Geoffrey Stone, Content Regulation and the First Amendment, 25 WM. \& MARY L. REV. 189, 189 (1983) [hereinafter Stone, Content Regulation]; Geoffrey R. Stone, Content-Neutral Restrictions, 54 U. CHI. L. REv. 46, 46 (1987) [hereinafter Stone, Content-Neutral Restrictions]; Paul B. Stephan III, The First Amendment and Content Discrimination, 68 VA. L. REv. 203, 214-31 (1982); Note, The Content Distinction in Free Speech Analysis After Renton, 102 HARV. L. REV. 1904, 1904 (1989). 
places are illustrations of content-neutral regulations. ${ }^{263}$ While content-based restrictions receive strict scrutiny, ${ }^{264}$ content-neutral regulations are reviewed under several varied standards. ${ }^{265}$

Because private execution statutes focus on preventing the subsequent broadcast of an execution, it has been argued that such restrictions impermissibly regulate content. ${ }^{266}$ Not only is this view in accord with libertarian principles of the First Amendment, it is consistent with Supreme Court precedent as well. ${ }^{267}$ For example, in Police Department of Chicago v. Mosley, ${ }^{268}$ the United States Supreme Court held that regulations enacted for the purpose of restraining speech on the basis of content presumptively violate the First Amendment. ${ }^{269}$ According to the Mosley Court:

[A]bove all else, the First Amendment means that government has no power to restrict expression because of its message, its ideas, its subject matter, or its content. ... To permit the continued building of our politics and culture, and to assure self-fulfillment for each individual, our people are guaranteed the right to express any thought, free from government censorship. The essence of this forbidden censorship is content control. Any restriction on expressive activity because of its content would completely undercut the "profound national commitment to the principle that debate on public issues should be uninhibited, robust, and wide-open."270

Indeed, members of the Supreme Court have also recognized the importance of television in conveying news to the general public.

263. Stone, Content-Neutral Restrictions, supra note 262, at 47-48; Stone, Content Regulation, supra note 262, at 189-90.

264. Content-based restrictions are subject to "the most exacting scrutiny." Texas v. Johnson, 491 U.S. 397, 412 (1989) (citing Boos v. Barry, 485 U.S. 312, 321 (1988)). To withstand such scrutiny, such restrictions will only be upheld if they are the least restrictive means of accomplishing a compelling governmental interest. Sable Communications v. FCC, 492 U.S. 115, 126 (1989); Boos, 485 U.S. at 321.

265. See Stone, Content-Neutral Restrictions, supra note 262, at 48 . As recently as 1987, Geoffrey Stone identified seven such standards of review, ranging from a highly deferential standard to a strict level of scrutiny. See id. at 48-54 (discussing the seven standards).

266. Comment, supra note 80 , at 747-48.

267. See id.

268. 408 U.S. 92 (1972).

269. Id. at 95, 98-99; see also City of Renton v. Playtime Theatres, Inc., 475 U.S. 41, 46-47 (1986); Carey v. Brown, 447 U.S. 455, 462-63 \& n.7 (1980). Restrictions on the content of first amendment expression may be justified only if a substantial governmental interest is found to exist. Mosley, 408 U.S. at 92.

270. Mosley, 408 U.S. at 95-96 (citations omitted) (quoting New York Times Co. v. Sullivan, 376 U.S. 254, 270 (1964)). 
As Justice Powell noted in Zacchini v. Scripps-Howard Broadcasting Co. "271 the public is the "loser" when news coverage is limited to "watered-down verbal reporting, perhaps with an occasional still picture."272 According to Justice Powell, "This is hardly the kind of news reportage that the First Amendment is meant to foster.",273

In Garrett, the United States Court of Appeals for the Fifth Circuit only briefly discussed content regulation. According to the court:

In order to sustain Garrett's argument we would have to find that the moving picture of the actual execution possessed some quality giving it "content" beyond, for example, that possessed by a simulation of the execution. We discern no such quality from the record or from our inferences therein. Despite the unavailability of film of the actual execution the public can be fully informed; the free flow of ideas and information need not be inhibited. ${ }^{274}$

However, in addressing content regulation so hastily, the Garrett court overlooked several important points. First, there

271. 433 U.S. 562 (1977).

272. Id. at 581 (Powell, J., dissenting).

273. Id.; see also Rideau v. Louisiana, 373 U.S. 723, 726 (1963) (noting the unique features of television in reversing a criminal conviction because of a televised confession); Cable News Network v. American Broadcasting Cos., 518 F. Supp. 1238, 1245 (N.D. Ga. 1981):

Many citizens likely rely on television as their sole source of news. Further, visual impressions can and sometimes do add a material dimension to one's impression of particular news events. Television film coverage of the news provides a comprehensive visual element and an immediacy, or simultaneous aspect, not found in print media .... [T] he importance of conveying the fullest information possible increases as the importance of the particular news event or news setting increases.

Society of Professional Journalists v. Secretary of Labor, 616 F. Supp. 576, 578 (D. Utah 1985) (citation omitted) (holding that there is a first amendment right of access to traditionally open administrative hearings and finding that furnishing a transcript is no substitute for television coverage):

The press and public are denied access to unfiltered information while it is still fresh. A stale transcript is not an adequate substitute for access to the hearings themselves. Emotions, gestures, facial expressions, and pregnant pauses do not appear on the reported transcript. Much of what makes good news is lost in the difference between a one-dimensional transcript and an opportunity to see and hear testimony as it unfolds.

People v. Thompson, 50 Cal.3d 134, 182, cert. denied, 498 U.S. 881 (1990) (noting that some events in the criminal process are "simply indescribable in mere words" and require photographic presentation); $c f$. Richmond Newspapers, 448 U.S. 555, 573, 577 n.12 (1980) (noting that people acquire information about the criminal process "chiefly through the print and electronic media").

274. Garrett v. Estelle, 556 F.2d 1274, 1278 (5th Cir. 1977). 
is a qualitative difference between watching an actual execution and a simulated execution. Watching a simulation of President Kennedy's assassination, for example, would not evoke the same emotions for many as watching the actual film footage. Because private execution laws, by definition, affect the "communicative impact" of the message journalists are able to convey, such content-based regulations must be struck down as unconstitutional. ${ }^{275}$ In fact, with television stations in the United States already broadcasting assassinations and executions in other countries, including executions in Iraq, Romania, Saudi Arabia and Vietnam, ${ }^{276}$ it is ironic and contrary to First Amendment principles that executions performed by our own government are deemed inappropriate for television audiences in the United States. Second, in addressing the issue of content regulation, the Garrett court ignored the fact that producing simulations is expensive and time-consuming. Indeed, if television stations are forced to produce their own execution simulations, political speech may be chilled. In this regard, the case of Minneapolis Star \& Tribune Co. v. Minnesota Commissioner of Revenue ${ }^{277}$ is instructive. There, a state use tax assessed a tax on the costs of

275. Televised executions would provide more reliable and accurate information about such events than eyewitness accounts. For example, the newspaper accounts of one execution indicates that the reporters had widely different versions of whether the condemned prisoner had to be wrestled into the execution chamber and what exactly the condemned prisoner said. While one report had the prisoner insanely shouting "I am Jesus Christ," another report had the prisoner resignedly muttering "Oh, my Jesus Christ." Other recollections also differed with the newspaper accounts. See Plaintiff's Post-Trial Brief at 22-23 \& n.18, KQED, Inc. v. Vasquez, 18 Media L. Rep. (BNA) 2323 (N.D. Cal. 1991) (No. C90-1383RHS); see also Angeja, supra note 124, at 1500 ("A television image can convey exactly what a spectator would see if she were present within the execution chamber."); Richards \& Easter, supra note 57, at 403 (footnote omitted) ("no simulation can provide precisely the same content (e.g., expressions on the face of the condemned) as the actual event"); MARSHaLL McLuhaN, UNDERSTANDING MEDIA: THE EXTENSIONS OF MAN 7 (1964) ("the medium is the message"); Zauderer v. Office of Disciplinary Counsel, 471 U.S. 626, 647 (1985) ("The use of illustrations or pictures in advertisements serves important communicative functions: it attracts the attention of the audience to the advertiser's message, and it may also serve to impart information directly. Accordingly, commercial illustrations are entitled to the First Amendment protections afforded verbal commercial speech ....").

276. Plaintiff's Trial Brief at 24, KQED, Inc. v. Vasquez, 18 Media L. Rep. (BNA) 2323 (N.D. Cal. 1991) (No. C90-1383RHS). Television broadcasts of assassinations have included, among others, John F. Kennedy, Robert Kennedy, Martin Luther King, Jr., and Lee Harvey Oswald. Id.

277. 460 U.S. 575 (1983). 
the ink and paper used in producing publications. ${ }^{278}$ However, because a provision exempted the first $\$ 100,000$ worth of ink and paper, the law as applied affected only a handful of the state's largest newspapers. ${ }^{279}$ While the Supreme Court found no evidence that the state legislature was attempting to impermissibly regulate the content of the papers, ${ }^{280}$ the Court subjected the law to strict scrutiny and held that the provision was unconstitutional under the First Amendment. ${ }^{281}$ The Court stated, "A tax that singles out the press, or that targets individual publications within the press, places a heavy burden on the State to justify its action." 282 Thus, if television stations are required to produce their own execution simulations in order to attempt to communicate their message, private execution statutes are unconstitutional as applied to television stations. ${ }^{283}$

The asserted justifications for private execution statutes clearly indicate that such regulations are "content-based." For instance, prison officials often express concerns about the impact of televised executions on inmates and other television viewers, including the fear that pictures of an execution will reveal the identity of witnesses or prison officials. Because these alleged concerns relate in toto to the communicative impact of televised broadcasts, private execution laws are obviously concerned with the regulation of the content of speech. ${ }^{284}$

278. Id. at 578 .

279. Id. at 578-79.

280. See id. at 592.

281. See id. at 591. According to the Court: "Whatever the motive of the legislature in this case, we think that recognizing a power in the State not only to single out the press but also to tailor the tax so that it singles out a few members of the press presents such a potential for abuse that no interest suggested by Minnesota can justify the scheme." Id. at 591-92.

282. Id. at 592-93.

283. Accord Arkansas Writers' Project, Inc. v. Ragland, 481 U.S. 221 (1987) (a sales tax that exempted certain classes of magazines was held unconstitutional); Board of Education v. Pico, 457 U.S. 853, 868 (1982) (recognizing a student's right of access to certain books in a high school library where the school board didn't ban the use of such books, but forced students to take the more expensive and less convenient route of acquiring the books from sources other than the school library); Grosjean v. American Press Co., 297 U.S. 233 (1936) (a license tax upon advertising receipts based on a newspaper's circulation was held unconstitutional because it attempted to limit the dissemination of information by placing a tax upon a select group of newspapers).

284. See Angeja, supra note 124, at 1506 (footnote omitted) ("Since cameras are allowed into prisons to televise other events, only the content of televised broadcasts of executions differentiates regulations concerning this particular use of the camera."). 
Because states can assert only "sham" interests to justify private execution statutes, ${ }^{285}$ such statutes must be declared unconstitutional. On the issue of prison security, for example, states have asserted that prison riots may occur or that prison staff or their families may be attacked or harassed by inmates or others who view an execution film. However, the presence of a camera in the execution chamber will not jeopardize prison security. ${ }^{286}$ First, given that prisoners can be confined to their cells during an execution, the possibility that prison riots will occur during executions is pure speculation. ${ }^{287}$ Second, fears that prison employees may be attacked or threatened assumes that an execution film will record the faces of prison personnel. However, as the plaintiffs suggested in $K Q E D$, less restrictive alternatives to address this concern include, inter alia, the use of "electronic masking" or screening prior to an execution film being broadcast or instructing a camera operator not to turn the camera on until the condemned person has been strapped into the gas chamber chair and the officers are out of sight.288 "Additionally, since television sets are conditionally provided to the

285. States may not offer "sham" justifications for a restriction on free speech. Thus, it has been held that a regulation affecting free speech rights is unconstitutional if "it does not sufficiently serve those public interests that are urged as its justification." United States v. Grace, 461 U.S. 171, 181 (1983); see also Greer v. Spock, 424 U.S. 828, 843 (1976) (Powell, J., concurring) ("any significant restriction of First Amendment freedoms carries a heavy burden of justification"); Heffron v. International Soc. for Krishna Consciousness, Inc., 452 U.S. 640, 658 (1981) (the burden of justifying a regulation affecting first amendment freedoms is on the government).

286. "[I] $t$ is unclear how viewing the inside of the private execution chamber jeopardizes prison security and safety-particularly if members of the press and public already have been granted physical access to the chamber." Tao, supra note 80 , at 1076 (footnote omitted).

287. First amendment restrictions can withstand constitutional scrutiny only where the danger is "likely" and "imminent." Brandenburg v. Ohio, 395 U.S. 444, 447 (1969); Tinker v. Des Moines Community Sch. Dist., 393 U.S. 503, 508 (1969).

288. See Plaintiff's Trial Brief at 19-21, KQED, Inc. v. Vasquez, 18 Media L. Rep. (BNA) 2323 (N.D. Cal. 1991) (No. C90-1383RHS); see also Richards \& Easter, supra note 57, at 411-12 (noting other alternatives that would be more "narrowly tailored" to serve the interests of prison security). In the challenge to California's private execution statute, there was substantial evidence that the real reasons for excluding television cameras from the execution chamber had nothing to do with prison security. See Plaintiff's Post-Trial Brief at 23-24, KQED, Inc. v. Vasquez, 18 Media L. Rep. 2323 (N.D. Cal. 1991) (No. C90-1383RHS) (witnesses gave the following reasons for not allowing public executions: "dignity," "don't want this turned into a circus," "thought it was not an appropriate item for public viewing," and "wouldn't be in good taste"). 
inmate population, restrictions could easily be levied on their use."289 A state's allegation, such as in the KQED case, that a camera may be thrown at the execution chamber glass is clearly a sham, as a camera easily could be bolted to the floor. ${ }^{290}$ Likewise, regardless of whether protecting children from watching an execution is a legitimate governmental concern, ${ }^{291}$ restricting the broadcast time of an execution is a less restrictive alternative than banning the broadcast altogether. ${ }^{292}$

That the real purpose of private execution laws is to prevent the general public from hearing about the details of executions is reinforced by several state statutes, which provide that executions only be conducted during the middle of the night or that the details of executions not be published at all. For example, in Louisiana, every execution is to take place between the hours of midnight and 3:00 a.m. ${ }^{293}$ Likewise, in South Dakota, where executions can only take place between the hours of 12:01 a.m. and 6:00 a.m., ${ }^{294}$ the statute makes it a misdemeanor for persons in-

289. Philbin, supra note 57, at 154 (footnote omitted). According to KQED's trial brief: "The fact that the defendant chooses to allow prisoners to have television sets, and apparently is unwilling to disconnect them when he thinks a particular program may be problematical, cannot justify blacking out the entire general public." This position, KQED asserted, would allow the "prisoner tail ... [to] wag the First Amendment dog." Plaintiff's Post-Trial Reply Brief at 8, KQED, Inc. v. Vasquez, 18 Media L. Rep. (N.D. Cal. 1991) (No. C90-1383RHS).

290. See Plaintiff's Post-Trial Brief at 23, KQED, Inc. v. Vasquez, 18 Media L. Rep. 2323 (N.D. Cal. 1991) (No. C90-1383RHS).

291. In Ginsberg v. New York, 390 U.S. 629 (1968), the Supreme Court held that the government's interest in the "well-being of its youth" and in supporting "parents" claim to authority in their own household" justified the regulation of otherwise protected expression. See FCC v. Pacifica Found., 438 U.S. 726, 749 (1978); Interstate Circuit, Inc. v. City of Dallas, 390 U.S. 676, 690 (1968). However, it is well-settled that "the government may not 'reduce the adult population . . . to ... only what is fit for children." "Sable Communications v. Federal Communications Commission, 492 U.S. 115, 128 (1989) (quoting Bolger v. Youngs Drug Prods. Corp., 463 U.S. 60, 73 (1983)).

292. See Consolidated Edison Co. v. Public Service Comm'n, 447 U.S. 530, 535 (1980) (a restriction which regulates "the time, place, or manner" of speech may be imposed so long as it is reasonable and so long as the restriction serves "a significant governmental interest" and leaves "ample alternative channels for communication"); cf. FCC v. Pacifica Found., 438 U.S. 726, 750 \& n.28 (1978) (emphasizing the "narrowness of [its] holding" and refusing to reach the issue of whether a broadcast late in the evening could be constitutionally prohibited, five members of the Supreme Court held that an FCC order that prohibited an early afternoon radio broadcast of a 12 minute monologue entitled "Filthy Words" did not violate the first amendment).

293. LA. REV. STAT. ANN. § 15:569.1 (West 1992).

294. S.D. CoDIFIED LAwS ANN. § 23A-27A-17 (1988). 
vited to attend the execution to disclose the exact time of the execution. ${ }^{295}$ Indeed, in Arkansas, it is unlawful for an individual to merely print or publish details of an execution. ${ }^{296} \mathrm{Un}$ doubtedly, such laws, on their face, impermissibly regulate the content of speech. 297

Although the Supreme Court has expressed an unwillingness to strike down statutes on the basis of illicit legislative motives, ${ }^{298}$ it is well-established that "regulations enacted for the purpose of restraining speech on the basis of its content presumptively violate the First Amendment."299 Because private execution laws remain in place for the paternalistic reasons for which they were originally enacted, such regulations presumptively violate the First Amendment. In this regard, it is significant that the Supreme Court has demonstrated a willingness to invalidate "sham" laws enacted for an "avowed" constitutional purpose. ${ }^{300}$

\section{However, regardless of whether private execution statutes}

295. Id. at § $23 \mathrm{~A}-27 \mathrm{~A}-37$ (1988).

296. See supra note 79 and accompanying text.

297. It is well-established that "the First Amendment forbids the government from regulating speech in ways that favor some viewpoints or ideas at the expense of others." City Council v. Taxpayers for Vincent, 466 U.S. 789, 804 (1984). Indeed, a regulation is considered content-based if it seeks to eliminate debate on an entire issue, even if the regulation does not " favor either side of a controversy." Boos v. Barry, 485 U.S. 312, 319 (1988) (plurality) (quoting Consolidated Edison, Co. v. Public Serv. Comm'n, 447 U.S. 530, 537 (1980)).

298. City of Renton v. Playtime Theatres, Inc., 475 U.S. 41, 47-48 (1986) (citing United States v. O'Brien, 391 U.S. 367, 382-86 (1968)). But see Ward v. Rock Against Racism, 491 U.S. 781, 791 (1988) (citation omitted) ("The principal inquiry in determining content-neutrality, in speech cases generally, and in time, place, or manner in particular, is whether the government has adopted a regulation because of disagreement with the message it conveys. The government's purpose is the controlling consideration.").

299. City of Renton, 475 U.S. at 46-47 (citing Carey v. Brown, 447 U.S. 455, $462-$ 63 \& n.7 (1980) and Police Department of Chicago v. Mosley, 408 U.S. 92, 95, 98-99 (1972)).

300. See Stone v. Graham, 449 U.S. 39 (1980) (Kentucky statute requiring the posting of copies of the Ten Commandments in public schools violated the establishment clause of the first amendment despite the fact that the statute's "avowed" purpose was "secular and not religious"); Edwards v. Aguillard, 482 U.S. 578, 586-87 (1987) ("While the Court is normally deferential to a state's articulation of a secular purpose, it is required that the statement of such purpose be sincere and not a sham."); $c f$. Rogers v. Lodge, 458 U.S. 613 (1982) (at-large election system unconstitutional where trial court evidence supported finding of intentional discrimination); Ward v. Rock Against Racism, 491 U.S. 781, 791 (1988) (emphasis added) ("The government's purpose is the controlling consideration" in first amendment analysis.) 
are considered "content-based" or "content-neutral,"301 the Supreme Court should find such laws unconstitutional because such regulations violate the court's anti-paternalistic understanding of the First Amendment and assume that the government knows best. ${ }^{302}$ Thus, private execution statutes violate the Supreme Court's First Amendment understanding that "information is not in itself harmful, that people will perceive their own best interests if only they are well enough informed, and that the best means to that end is to open the channels of communication rather than to close them." ${ }^{303}$ Furthermore, the enforcement of private execution statutes runs contrary to the Court's observation in First Nat'l Bank of Boston v. Bellotti: ${ }^{304}$ "[T] he people in our democracy are entrusted with the responsibility for judging and evaluating the relative merits of conflicting arguments ... [and] if there be any danger that the people cannot evaluate the information and arguments ... it is a danger contemplated by the Framers of the First Amendment." 305 As the Supreme Court recently reiterated, "[A] principal 'function of free speech under our system of government is to invite dis-

301. Philbin, supra note 57, at 153 ("In the cases examined thus far, the states have successfully argued that [media tool] restrictions were not content-based, but were instead content-neutral restrictions grounded in security and privacy concerns.").

302. See Stone, Content Regulation, supra note 262, at 212-14.

303. Virginia State Bd. of Pharmacy v. Virginia Citizens Consumer Council, 425 U.S. 748, 770 (1976); see also Benjamin Lombard, Note, First Amendment Limits on the Use of Taxes to Subsidize Selectively the Media, 78 CoRNELl L. REV. 106, 125 ("The Supreme Court has recognized a constitutional right to receive information and ideas as a necessary corollary to the right to speak.") (emphasis added); Richards \& Easter, supra note 57, at 393 n. 59 (citing cases finding a right to receive information). The "right to receive" information has been extended to "personal correspondence, political and religious material, commercial information, pornography, and information and ideas generally." Michael J. Hayes, Note, What Ever Happened to "The Right to Know"?: Access to Government-Controlled Information Since Richmond Newspapers, 73 VA. L. REV. 1111,1114 (1987) (footnotes omitted). Even when content-neutral regulations are subjected to "rational basis" review, such regulations must leave open alternative methods of disseminating the relevant information. See Consolidated Edison Co. v. Public Serv. Comm'n, 447 U.S. 530, 535 (1980); Lloyd Corp. v. Tanner, 407 U.S. 551, 556-67 \& n.12 (1972).

304. 435 U.S. 765 (1978).

305. Id. at 791-92; see also Cohen v. California, 403 U.S. 15, 24 (1971) ("The constitutional right of free expression is ... intended to remove governmental restraints from the arena of public discussion, putting the decision as to what views shall be voiced largely into the hands of each of us . . . in the belief that no other approach would comport with the premise of individual dignity and choice upon which our political system rests."). 
pute. It may indeed best serve its high purpose when it induces a condition of unrest, creates dissatisfaction with conditions as they are, or even stirs people to anger.' "306 Thus, "[i]f there is a bedrock principle underlying the First Amendment, it is that the government may not prohibit the expression of an idea simply because society finds the idea itself offensive or disagreeable."307

\section{Right of Access}

In the landmark decision of Richmond Newspapers, Inc. v. Commonwealth of Virginia, ${ }^{308}$ the Supreme Court recognized the public's First Amendment right to attend criminal trials. In that case, Chief Justice Burger observed that it is not crucial whether the right to attend criminal trials is described as a "right of access" or a "right to gather information."309 For, as Burger noted in his plurality opinion, the Court has "recognized that "without some protection for seeking out the news, freedom of the press could be eviscerated." "310 Moreover, the rights "to speak and to publish concerning what takes place at a trial would lose much meaning if access to observe the trial could . . . be foreclosed arbitrarily." 311

Since Richmond Newspapers, the Supreme Court has acknowledged a broader right of access to gather information. In 1982, for example, the Court in Globe Newspaper Co. v. Superior Court ${ }^{312}$ considered a challenge to a statute allowing automatic trial closure for sexual offense cases involving minor victims. ${ }^{313}$ Recognizing that the right to attend criminal trials is not abso-

306. Texas v. Johnson, 491 U.S. 397, 408-09 (1989) (quoting Terminiello v. Chicago, 337 U.S. 1, 4 (1949)). Notably, in Boos v. Barry, 485 U.S. 312, 320 (1988), where a law prohibiting the display of picketing signs within a certain distance of foreign embassies was struck down, the Supreme Court reiterated its " "Iong-standing refusal' " to punish speech because the particular speech may have " 'an adverse emotional impact on the audience." II. at 322 (quoting Hustler Magazine, Inc. v. Falwell, 485 U.S. 46, 56 (1988)). For a detailed discussion of the "secondary effects" doctrine in the context of televised executions, see Tao, supra note 80, at 1073-75. Also, for a discussion of "conduct," as opposed to "speech," in the context of televised executions, see id. at 1072-73.

307. Texas v. Johnson, 491 U.S. 397, 414 (1989).

308. 448 U.S. 555 (1980).

309. Richmond Newspapers, 448 U.S. at 576.

310. Id. (quoting Branzburg v. Hayes, 408 U.S. 665, 681 (1972)).

311. Id. at 576-77 (footnote omitted).

312. 457 U.S. 596 (1982).

313. Id. at 598 n.1. 
lute, the Court discussed the right of access in terms of its historical roots and its vital role in the judicial process. ${ }^{314}$ Ultimately, the Court concluded that where a state "attempts to deny the right of access in order to inhibit the disclosure of sensitive information, it must be shown that the denial is necessitated by a compelling governmental interest, and is narrowly tailored to serve that interest." ${ }^{15}$ While the Court agreed that the state has a compelling interest in safeguarding victims from additional trauma, the Court held that the mandatory closure rule was too restrictive and thus violative of the First Amendment. ${ }^{316}$

In Press-Enterprise Co. v. Superior Court, ${ }^{317}$ the Supreme Court also broadened the right to gather information. In that case, the Court held that the guarantees of open public proceedings cover proceedings for the voir dire examination of potential jurors. Citing the importance of history utilized in Richmond Newspapers, the Court in Press-Enterprise also used historical evidence in concluding that juries have traditionally been selected in public. ${ }^{318}$ Indeed, the Court concluded that the presumption of openness could only be overcome by a compelling state interest that is narrowly tailored to serve that interest. ${ }^{319}$

Lower courts have also extended the rationale of Richmond Newspapers into other areas. For example, in Westmoreland $v$. Columbia Broadcasting System, Inc. ${ }^{320}$ and Publicker Industries, Inc. v. Cohen, ${ }^{321}$ the United States Courts of Appeals for the Sec-

314. Id. at 605-06.

315. Id. at 606-07.

316. Id. at $607-11$. Emphasizing that cases must be resolved on a case-by-case basis, the Court spoke in the following terms:

In individual cases, and under appropriate circumstances, the First Amendment does not necessarily stand as a bar to the exclusion from the courtroom of the press and general public during the testimony of minor sex-offense victims. But a mandatory rule, requiring no particularized determinations in individual cases, is unconstitutional.

Id. at $611 \mathrm{n} .27$.

317. 464 U.S. 501 (1984).

318. The Press-Enterprise Court traced the jury selection process back to the Norman Conquest and noted that "[p]ublic jury selection ... was the common practice in America when the Constitution was adopted." Id. at 505-08.

319. Id. at 510; see also Press-Enterprise Co. v. Superior Court, 478 U.S. 1 (1986) (holding that the public has a right of access to preliminary hearings).

320. 752 F.2d 16, 23 (2d Cir. 1984), cert. denied, 472 U.S. 1017 (1985).

321. 733 F.2d 1059 (3d Cir. 1984). The Second Circuit and the Sixth Circuit have also held that a right of access exists to civil proceedings. See gerierally Westmoreland v. Columbia Broadcasting Sys., 752 F.2d 16 (2d Cir. 1984), cert. denied, 472 U.S. 1017 
ond and Third Circuits held that there is a constitutional right of access to attend civil trials. In short, civil proceedings have been held to implicate the same First Amendment rights as criminal trials. ${ }^{322}$ Once again, the presumption of openness can only be overcome by an overriding governmental interest and a lack of viable alternatives.

Because executions have historically been open to the general public, the public has a constitutional right of access to attend executions. Not only does allowing such access "protect the free discussion of governmental affairs," that individual citizens can effectively participate and contribute to the American system of self-government. ${ }^{324}$ Indeed, as the Court articulated in Richmond Newspapers, Inc. v. Commonwealth of Virginia, ${ }^{325}$ "To work effectively, it is important that society's criminal process 'satisfy the appearance of justice,' and the appearance of justice can best be provided by allowing people to observe it." 326 As the Court continued, "People in an open society do not demand infallibility from their institutions, but it is difficult for them to accept what they are prohibited from observing." 327

Furthermore, a constitutional right of access to attend executions should not be inhibited merely because such events

(1985); Brown \& Williamson Tobacco Corp. v. FTC, 710 F.2d 1165 (6th Cir. 1983), cert. denied, 465 U.S. 1100 (1984).

322. Publicker, 733 F.2d at 1067-71. As the Third Circuit stated:

From the foregoing discussion it becomes clear that the public and the press possess a First Amendment and a common law right of access to civil proceedings; indeed, there is a presumption that these proceedings will be open.

The trial court may limit this right, however, when an important countervailing interest is shown.

Id. at 1071 .

323. Mills v. Alabama, 384 U.S. 214, 218 (1966). Protecting the free discussion of governmental affairs was cited by the Globe Newspaper Court as being an underlying purpose of the first amendment right of access to criminal trials. Globe Newspaper Co. v. Superior Ct., 457 U.S. 596, 604 (1982).

324. See Richmond Newspapers, Inc. v. Virginia, 448 U.S. 555, 587-88 (1980); Thornhill v. Alabama, 310 U.S. 88, 95 (1940).

325. 448 U.S. 555 (1980).

326. Id. at 571-72 (quoting Offutt v. United States, 348 U.S. 11, 14 (1954) (citation omitted)).

327. Id. at 572. Information about the criminal justice system is "of critical importance to our type of government in which the citizenry is the final judge of the proper conduct of public business." Cox Broadcasting Corp. v. Cohn, 420 U.S. 469, 495 (1975). 
were privatized over the course of the last 150 years. Considering the centuries' old practice of public executions in Europe and the well-established tradition of public executions in the United States before the 1830 s and until $1937,{ }^{328}$ this amount of time is de minimis. Indeed, especially considering the fact that television and radio are modern technologies, it would be illogical to punish modern day litigants on the ground that previous generations failed to challenge private execution statutes until the 1970 s in Garrett v. Estelle. ${ }^{329}$ In short, states should not be dealt a "constitutional waiver" trump card just because the well-established practice of public executions was changed in the United States during the nineteenth and early twentieth centuries. ${ }^{330}$

However, all of this is not to suggest that executions must now be conducted in Central Park or downtown Dallas. Given modern day technology, broadcast journalists - acting as surrogates for the people - can easily film executions and transmit the footage to American households via videotape or television. Thus, whereas physical space limitations might have posed problems in the past, the advent of television and video technology allows government officials to continue conducting executions in prisons while allowing the general public to "witness" the event. However, "[i]n such situations, representatives of the press must be assured access." 331 Televising executions will allow the general public to debate, in a real way, the morality of capital punishment. ${ }^{332}$

328. See supra Section II.

329. 424 F. Supp. 468 (N.D. Tex.), rev'd, 556 F.2d 1274 (5th Cir. 1977).

330. See supra Section II. Notably, one commentator has argued that "history does not demonstrate an unbroken tradition of press and public access to executions" and that this conclusion "precludes a finding that executions "historically ha[ve] been open to the press and general public.'" Dave A. Drobny, Note, Death TV: Media Access to Executions Under the First Amendment, 70 WASH U. L.Q. 1179, 1201-02 (1992) (citing Globe Newspaper Co. v. Superior Ct., 457 U.S. 596, 605 (1982)). However, what this commentator fails to recognize is that even modern-day private execution statutes generally allow for the attendance of some members of the public. See supra notes 66-72 (citing several statutes that mandate the attendance of a certain number of "reputable" citizens). Thus, the general public has never been truly barred from execution proceedings.

331. Richmond Newspapers, 448 U.S. at 600 n.3.

332. Cf. Times Publishing Co. v. Florida, 5 Media L. Rep. (BNA) 1861, 1863 (Fla. Dist. Ct. App. 1979) (Florida Department of Corrections emergency rule canceling all regularly scheduled interviews with condemned prisoners until death warrant "is executed, expires, or is stayed," is invalid as applied to particular prisoner whose death 


\section{B. Equal Protection Analysis}

In Police Department of Chicago v. Mosley ${ }^{333}$ the Supreme Court held that the Equal Protection clause requires that statutes affecting First Amendment interests be narrowly tailored to their legitimate objectives. ${ }^{334}$ In practice, however, the Supreme Court has both embraced ${ }^{335}$ and eschewed ${ }^{336}$ reliance on the Equal Protection clause when deciding First Amendment issues. This has led one scholar to remark that "[i]nvocation of the equal protection clause" may only "deflect attention" from the central First Amendment issue. ${ }^{337}$ Thus, although courts have held that governmental entities cannot deny access to some members of the press while granting access to others, ${ }^{338}$ such Equal Protection cases may only distract from the more fundamental "content regulation" issue that private execution statutes raise.

warrant is outstanding, because interviews with condemned prisoners whose deaths are imminent are "uniquely of interest to a public which continues to debate the morality of capital punishment").

An individual's "right to know" originates with "the widely accepted principle that the core value protected by the first amendment is the citizen's right to participate in America's representative democracy." Hayes., supra note 303, at 1113; see also Vincent Blasi, The Checking Value in First Amendment Theory, 1977 AM. B. Found. RESEARCH J. 521, 593 (freedom of expression acts as a watchdog of the government). The framers of the Constitution explicitly recognized the important role that access to information plays in a representative democracy. See Bill for the More General Diffusion of Knowledge (T. Jefferson) in 2 THE WRITINGS OF THOMAS JEFFERSON 220-21 (Paul L. Ford ed., 1893) ("[W] hereas ... experience hath shewn, that even under the best forms, those entrusted with power have, in time ... perverted it into tyranny; and it is believed that the most effectual means of preventing this would be, to illuminate, as far as practicable, the minds of the people at large. . . ."); Letter from James Madison to W.T. Barry, Aug. 4, 1822, in 9 WRITINGS OF JAMES MAdISON 103 (Gaillard Hunt ed., 1910) ("A popular government, without popular information or the means of acquiring it, is but a prologue to a farce or a tragedy; or perhaps both. Knowledge will forever govern ignorance. And a people who mean to be their own governors, must arm themselves with the power which knowledge gives.").

333. 408 U.S. 92 (1972).

334. Id. at 101.

335. See, e.g., Carey v. Brown, 447 U.S. 455 (1980); Erznoznik v. City of Jacksonville, 422 U.S. 205 (1975).

336. See, e.g., Widmar v. Vincent, 454 U.S. 263 (1981); Consolidated Edison Co. v. Public Serv. Comm'n, 447 U.S. 530 (1980).

337. Stone, Content Regulation, supra note 262, at 206.

338. See, e.g., Quad-City Community News Service, Inc. v. Jebens, 334 F. Supp. 8, 15 (S.D. Iowa 1971) ('Defendants' denial of access by Quad-City to records available to the other media presents an obvious case of denial of equal protection of the law in violation of the Fourteenth Amendment of the federal Constitution."). 
In comparing the areas of content regulation and Equal Protection, it has been argued that the notion of equality "lies at the heart of the First Amendment's protections against governmental regulation of the content of speech." ${ }^{339}$ Indeed, according to the Dean of the University of Chicago Law School, Geoffrey Stone, there is an obvious connection between the concept of equality and the "content-based"/"content-neutral" distinction. For, when government restricts only certain ideas or items of information, people wishing to articulate the restricted viewpoint or information receive "unequal" treatment. ${ }^{340}$ However, as Stone points out, there are dangers in emphasizing equality. "By focusing on equality," Stone writes, "the Court may invite government to 'equalize,' not by permitting more speech, but by adopting even more 'suppressive' content-neutral restrictions." ${ }^{341}$ Obviously, the attempt by California officials in $K Q E D$ to prohibit all journalists from witnessing the execution of Robert Alton Harris illustrates the danger of Equal Protection challenges to private execution statutes. ${ }^{342}$

\section{Right of Privacy Analysis}

In his 1928 dissent in Olmstead v. United States, ${ }^{343}$ Justice Louis Brandeis defined the constitutional right of privacy as "the right to be let alone - the most comprehensive of rights and the right most valued by civilized men." ${ }^{344}$ As Laurence Tribe

339. Kenneth L. Karst, Equality as a Central Principle in the First Amendment, 43 U. CHI. L. REv. 20, 21 (1975). According to Karst, "[j]ust as the prohibition of government-imposed discrimination on the basis of race is central to equal protection analysis, protection against governmental discrimination on the basis of speech content is central among first amendment values." Id. at 35.

340. Stone, Content Regulation, supra note 262, at 202.

341. Id. at 205; see also Roy A. Black, Case Comment, Equal But Inadequate Protection: A Look at Mosley and Grayned, 8 HARV. C.R.-C.L. L. REV. 469 (1973) (criticizing the reliance on equal protection analysis in first amendment cases).

342. See supra notes 110-12 and accompanying text. But cf. Smith v. Daily Mail Publishing Co., 443 U.S. 97 (1979) (a West Virginia statute prohibiting newspapers from publishing the name of a juvenile offender was unconstitutional because it applied to newspapers alone); Florida Star v. B.J.F., 491 U.S. 524, 540 (1989) (emphasis added) ("When a state attempts the extraordinary measure of punishing truthful publication in the name of privacy, it must demonstrate its commitment to advancing this interest by applying its prohibition evenhandedly, to the smalltime disseminator as well as the media giant.").

343. 277 U.S. 438 (1928).

344. Id. at 478 (Brandeis, J., dissenting). 
points out, that formulation reveals the paradox of the right of privacy: "[I]t is revered by those who live within civil society as a means of repudiating the claims that civil society would make of them." 345 Human beings are social creatures, yet "the concept of privacy embodies the 'moral fact that a person belongs to himself and not others nor to society as a whole." "346 Speaking for a unanimous Court in Whalen v. Roe, ${ }^{347}$ Justice Stevens stated that this paradoxical right includes an "individual interest in avoiding disclosure of personal matters" and an "interest in independence in making certain kinds of important decisions." 348

According to the Supreme Court, although it is a "familiar proposition" that inmates lose many rights when they are lawfully confined, ${ }^{349}$ it is also true that prisoners do not lose all civil liberties. ${ }^{350}$ As Chief Justice Burger noted in his plurality opinion in Houchins v. KQED, Inc. :351 "Inmates in jails, prisons, or mental institutions retain certain fundamental rights of privacy; they are not like animals in a zoo to be filmed and photographed at will by the public or by media reporters, however 'educational' the process may be for others." 352

Because prisoners retain a constitutional right of privacy, in deciding whether executions may be televised over an inmate's objection, this right of privacy must be balanced against other competing "rights." For, while granting the condemned's last request may seem reasonable, a sound jurisprudence recognizes that the law "mediates most significantly between right and right." ${ }^{353}$ In the execution setting, the competing "rights,"

345. TRIBE, supra note 200 , at 1302.

346. Thornburgh v. American College of Obstetricians \& Gynecologists, 476 U.S. 747, 777 n.5 (1986) (Stevens, J., concurring) (quoting Fried, Correspondence, 6 PHIL. \& PUB. AFFAIRs 288, 288-89 (1977)); see also TRIBE, supra note 200, $\S 15-1$, at 1302.

347. 429 U.S. 589 (1977).

348. Id. at $599-600$.

349. Pell v. Procunier, 417 U.S. 817, 822 (1974).

350. See, e.g., Wolff v. McDonnell, 418 U.S. 539, $555-56$ (1974) (listing several prisoner rights); Hudson v. Palmer, 468 U.S. 517, 523 (1984) ("We have repeatedly held that prisons are not beyond the reach of the Constitution. No 'iron curtain' separates one from the other.").

351. 438 U.S. 1 (1978).

352. Id. at 5 n.2.

353. Paul A. Freund, Legal Frameworks for Human Experimentation, in EXPERIMentation with Human Subjects 105, 105 (Paul A. Freund ed., 1970). 
along with the condemned's privacy interest, include the public's interest in witnessing executions and the state's interest in deterrence.

In balancing these interests, courts should consider several factors. First, the public's interest in witnessing executions should be accorded significant weight. For, not only will televised executions further the goal of an informed self-government, but such events can create societal consensus on capital punishment issues. ${ }^{354}$ Second, because deterrence is a legitimate legislative rationale for the death penalty, ${ }^{355}$ a state's desire to televise executions should receive attention because televised executions might arguably deter capital crimes. ${ }^{356}$ Finally, against the interests of the public and the states, courts should consider an inmate's wishes. On this point, the approach of Justice Brennan's dissent in Cruzan v. Director, Missouri Department of Health, ${ }^{357}$ the "right-to-die" case, seems particularly apt: "Dying is personal. And it is profound. For many, the thought of an ignoble end ... is abhorrent. A quiet, proud death . . . is a matter of extreme consequence."358

Notwithstanding Justice Brennan's eloquent language in Cruzan, the Supreme Court is unlikely to allow a condemned inmate's privacy interests to outweigh those of the public or the states. By way of analogy, consider the case of Cox Broadcasting Corp. v. Cohn. ${ }^{359}$ In Cox, the identity of a seventeen-year-old deceased rape victim was obtained through public records and broadcast on television. The victim's father brought suit against the reporter and the television station for invasion of privacy,

354. See infra notes $411-13$ and accompanying text.

355. Gregg v. Georgia, 428 U.S. 153, 185-86 (1976) ("The value of capital punishment as a deterrent of crime is a complex factual issue the resolution of which properly rests with the legislatures, which can evaluate the results of statistical studies in terms of their own local conditions and with a flexibility of approach that is not available to the courts.").

356. See supra, note 1.

357. 497 U.S. 271 (1990).

358. Id. at 310 (Brennan, J., dissenting). Likewise, as one commentator has noted in the public execution context: "Sharing his pain and suffering with unrelated observers should not necessarily be part of the penalty the prisoner pays for his crime." Mamantov, supra note 9, at 401. But cf. Cruzan, 497 U.S. at 279 n.7 (citing Bowers v. Hardwick, 478 U.S. 186, 194-95 (1986)) (Chief Justice Rehnquist did not characterize the right to refuse treatment as a privacy right; rather, he framed the issue as one more properly analyzed in terms of a fourteenth amendment "liberty interest.")

359. 420 U.S. 469 (1975). 
grounded upon a Georgia statute making it a misdemeanor to broadcast the name of a rape victim. ${ }^{360}$ In ruling that Georgia was barred from making the defendant's telecasts the basis of civil liability, the Supreme Court favored the press in this "sphere of collision" between privacy and free press claims. ${ }^{361}$ The Court stated, "We are reluctant to embark on a course that would make public records generally available to the media but forbid their publication if offensive to the sensibilities of the supposed reasonable man."362 Because a statutory prohibition against the disclosure of a rape victim's name in Cox constituted an insufficient competing interest vis-à-vis the press, the Supreme Court is unlikely to preserve the privacy of a notorious criminal in the face of the public's right to know about his or her execution. ${ }^{363}$

360. Id. at $473-74$.

361. Id. at 491 .

362. Id. at 496; see also id. at 491 ("II]n a society in which each individual has but limited time and resources with which to observe at first hand the operations of his government, he relies necessarily upon the press to bring to him in convenient form the facts of those operations."); id. at 492 ("Without the information provided by the press most of us and many of our representatives would be unable to vote intelligently or to register opinions on the administration of government generally.").

363. Comment, supra note 80, at 739; Angeja, supra note 124, at 1507-10; see also Comment, supra note 80, at 739 (footnotes omitted) (quoting Pell, 417 U.S. at 822) ("Although there appeared to be a substantial public interest in favor of withholding the rape victim's identity in Cox, there does not appear to be any public interest served by preserving the privacy of a notorious criminal, especially in light of the 'familiar proposition' that incarceration limits the retention of many privileges and rights."); Tao, supra note 80, at 1076 ("Even absent [the prisoner's] consent, it is difficult to reconcile [the condemned's privacy] interest with statutes such as that in effect in California, which mandate semi-public executions by requiring the presence in the execution chamber of witnesses other than prison officials and those selected by the condemned.").

According to one commentator, condemned prisoners cannot avoid press coverage because they are already the object of such extensive reporting that they have become "public figures." Comment, supra note 80, at 740 n.131 (citing Gertz v. Robert Welch, Inc., 418 U.S. 323, 342, 351 (1974)); see also Van Straten v. Milwaukee Journal Newspaper-Publisher, 447 N.W.2d 105 (Wis. App. 1989), cert. denied, 496 U.S. 929 (1990) (inmate was limited purpose public figure who failed to make required showing of actual malice in a defamation action against several newspapers); Cox Communications, Inc. v. Lowe, 328 S.E.2d 384 (Ga. App.), cert. denied 474 U.S. 982 (1985) (television station was not liable for invasion of prison inmate's privacy by disclosing fact that he was incarcerated, intruding upon his seclusion, portraying him in a false light or appropriating his likeness in pursuit of pecuniary gain, where inmate only incidentally appeared in background of broadcast report concerning alleged abuses by prison officials, in light of legitimate public interest served by broadcast); Huskey v. Dallas Chronicle, 13 Media L. Rep. (BNA) 1057 (D. Or. 1986) (newspa- 
Even if legislatures were given discretion to enact appropriate legislation in the privacy area, ${ }^{364}$ private executions would still be unconstitutional where the condemned person consents to the publicity. Indeed, in cases where a condemned person wants to have the execution filmed, it would be quite perverse to deny him or her this final request on the ground that it violated his or her own right of privacy. For this reason, any legislative scheme providing for a private execution based upon the right of privacy must be waivable at the condemned inmate's request. ${ }^{365}$

\section{INTEGRATING THE FIRST AMENDMENT WITH TROP V. DULLES}

\section{The First and Eighth Amendments to the United States}

per's publication, in connection with news story concerning plaintiff prisoner's escape from custody, of photograph that was taken inside jail and that depicted plaintiff being booked does not invade plaintiff's privacy); Haynik v. Zimlich, 508 N.E.2d 195 (Ohio. Com. P1. 1986) (news reports by media concerning plaintiff's arrest and indictment could not, as a matter of law, form the basis for a claim of intrusion upon seclusion because matters broadcast had nothing to do with plaintiff's secret, secluded, or private concerns, but were matters already within public realm at time of reports); Holman v. Central Arkansas Broadcasting, 610 F.2d 542 (8th Cir. 1979) (police officers, in allowing radio station reporter access to jail block, did not violate attorney's right to privacy, because no right to privacy is invaded when state officials facilitate publication of official act such as arrest); Seale v. Manson, 326 F. Supp. 1375 (D. Conn. 1971) (a prison regulation was upheld where it allowed reporters access to a prison for stories related to prison life and conditions). But see Huskey v. National Broadcasting Co., 632 F. Supp. 1282 (N.D. Ill. 1986) (prisoner, who had been filmed while in "exercise cage," wearing only gym shorts, leaving certain distinct tattoos exposed, who alleged, in his complaint, that he was engaged in "private activities," stated claim for invasion of privacy).

364. One commentator has argued that, regardless of whether the Supreme Court finds a constitutional right of access to executions, "independent policy concerns dictate that state legislatures grant at least a limited right of public and press access to executions." Mamantov, supra note 9, at 374-75.

365. See Mamantov, supra note 9, at 403. In California's $K Q E D$ case, the condemned killer, Robert Alton Harris, said he would have "no problem" with television cameras recording his execution. In a telephone interview with San Diego television station KGTV, Harris said that a televised execution might change some minds about capital punishment. "I think that the public is blind to just what type of ordeal a person goes through when he's executed," he said. "And that may have a bearing on the public opinion on the death penalty in general." Associated Press, Condemned Killer: "No Problem" with Televised Execution, June 14, 1991, available in LEXIS, Nexis Library, Current File. A recent survey of death row inmates in Florida revealed substantial support for televised executions among the death row population. See Richards \& Easter, supra note 57, at 419 \& n.164 (citing survey results from the Committee on Corrections, Florida House of Representatives, indicating that twenty-one inmates, out of twenty-nine survey responses, favored televising executions). 
Constitution serve widely divergent purposes. While the First Amendment protects free speech rights, including the right to engage in political discourse, ${ }^{366}$ the Eighth Amendment prohibits states from inflicting "cruel and unusual punishments." 367 At first blush, these two amendments do not appear to compliment each other in any way. Yet, with respect to the constitutionality of private execution statutes, this Article argues that Eighth Amendment principles, first developed in Trop v. Dulles, ${ }^{368}$ play a role in First Amendment jurisprudence.

\section{A. "Evolving Standards of Decency" and "Human Dignity"}

According to the Eighth Amendment, "Excessive bail shall not be required, nor excessive fines imposed, nor cruel and unusual punishments inflicted." ${ }^{369}$ Although what constitutes a "cruel and unusual punishment" is difficult to delineate, the Supreme Court has developed several tests to determine the constitutionality of a particular punishment. In discussing the interaction of the First and Eighth Amendments, two Eighth Amendment principles are relevant.

First, under Trop v. Dulles, ${ }^{370}$ a punishment must not offend the "evolving standards of decency that mark the progress of a maturing society." ${ }^{371}$ In determining to what extent society's standards have "evolved," members of the Supreme Court look "not to [their] own conceptions of decency, but to those of modern American society as a whole." ${ }^{372}$ As the Court stated in Coker v. Georgia, ${ }^{373}$ "Eighth Amendment judgments should not be, or appear to be, merely the subjective views of individual Justices; judgment should be informed by objective factors to the

366. The complete text of the first amendment reads: "Congress shall make no law respecting an establishment of religion, or prohibiting the free exercise thereof; or abridging the freedom of speech, or of the press; or the right of the people peaceably to assemble, and to petition the Government for a redress of grievances." U.S. CoNST., amend. I.

367. U.S. CoNST. amend. VIII.

368. 356 U.S. 86 (1958).

369. U.S. CoNST. amend. VIII; see also Robinson v. California, 370 U.S. 660,666 (1962) (the eighth amendment held applicable to the states through the due process clause of the fourteenth amendment).

370. 356 U.S. 86 (1958).

371. Id. at 101 .

372. Stanford v. Kentucky, 492 U.S. 361,369 (1989) (footnote omitted).

373. 433 U.S. 584 (1977) (plurality opinion). 
maximum possible extent."374 Foremost among the "objective indicia that reflect the public attitude toward a given sanction' ", are statutes passed by elected representatives. ${ }^{375}$ Other objective indicia used to determine modern conceptions of decency include the history of a particular punishment, jury verdicts, and international opinion. ${ }^{376}$

Second, under Eighth Amendment jurisprudence, a penalty must not offend the "dignity of man"-the "basic concept underlying the Eighth Amendment." 377 To violate the human dignity principle, the Supreme Court has held that a punishment must be "excessive." 378 A punishment is unconstitutionally excessive if it makes no measurable contribution to the accepted goals of punishment or is grossly disproportionate to the severity of the crime. ${ }^{379}$

As articulated in Gregg, a penalty "so totally without penological justification that it results in the gratuitous infliction of suffering" violates the human dignity principle. ${ }^{380}$ According to

374. Id. at 592.

375. McCleskey v. Kemp, 481 U.S. 279, 300 (1987) (quoting Gregg v. Georgia, 428 U.S. 153, 173 (1976)).

376. See generally Lawrence A. Vanor, Note, The Decency of Capital Punishment for Minors: Contemporary Standards and the Dignity of Juveniles, 61 IND. L.J. 757, 763 (1986) (discussing objective indicia). Notably, some commentators list public opinion polls as an "objective indicia." See, e.g., William Wilson, Note, Juvenile Offenders and the Electric Chair: Cruel and Unusual Punishment or Firm Discipline for the Hopelessly Delinquent?, 35 U. FIA. L. REV. 344, 362 (1983). However, for the most part, the Supreme Court has rejected the use of direct public opinion surveys in favor of legislative enactments and jury sentencing decisions. See, e.g., Stanford v. Kentucky, 492 U.S. 361, 377 (1989) (declining to use public opinion polls in the eighth amendment context); Gregg v. Georgia, 428 U.S. 153, 174 (1976) (legislation weighs heavily in ascertaining contemporary standards); Witherspoon v. Illinois, 391 U.S. 510,519 n.15 (1968) (one of the most important functions a jury performs is maintaining a link between community values and the penal system).

377. Trop v. Dulles, 356 U.S. 86 (1958); Gregg, 428 U.S. at 173. Notably, Justice Brennan once rejected the notion of public executions in dicta:

Our concern for decency and human dignity, moreover, has compelled changes in the circumstances surrounding the execution itself. No longer does our society countenance the spectacle of public executions, once thought desirable as a deterrent to criminal behavior by others. Today we reject public executions as debasing and brutalizing to us all.

Furman v. Georgia, 408 U.S. 238, 297 (1972) (Brennan, J., concurring).

378. Gregg, 428 U.S. at 173, 187 n.35; see also Enmund v. Florida, 458 U.S. 782, 788 (1982).

379. Coker v. Georgia, 433 U.S. 584, 592 (1977) (plurality opinion); Gregg, 428 U.S. at 173.

380. Gregg, 428 U.S. at $182-83$. 
Supreme Court precedent, the two penological goals that the death penalty serves are deterrence of capital crimes by prospective offenders and retribution. ${ }^{381}$ While the Court has noted that some studies suggest that "the death penalty may not function as a significantly greater deterrent than lesser penalties," 382 the Court has been willing to defer to the judgments of the state legislatures in this area. ${ }^{383}$ The death penalty fulfills its retributive purpose "by providing an institutional means for society to express its moral outrage at particularly offensive conduct, and by satisfying society's desire that criminals receive the punishments they deserve." 384

To satisfy the human dignity principle, a punishment also must be proportionate to the severity of the crime. If an offender receives more punishment than he deserves, then the punishment is considered disproportionate. ${ }^{385}$ In Coker, for instance, the Supreme Court held that the death penalty is always disproportionate to the crime of rape because rapists do not take their victims' lives. ${ }^{386}$ Likewise, in Enmund v. Florida, ${ }^{387}$ the Supreme Court held that capital punishment is excessive for the crime of robbery. ${ }^{388}$ Thus, in considering the constitutionality of a particular punishment, courts must weigh the punishment's severity against the degree of harm done to the victim. ${ }^{389}$

\section{B. Implications for Private Execution Statutes}

Because statutes passed by elected representatives are first among the "objective indicia" used to measure society's evolving standards with respect to criminal punishments, one might suspect that televised executions violate the Eighth Amendment. For, with legislators from every state with capital punishment having enacted private execution laws, televised executions

381. Id. at $182-83$.

382. Id. at $185-88$.

383. See, e.g., id. at 185-86 ("The value of capital punishment as a deterrent of crime is a complex factual issue the resolution of which properly rests with the legislatures, which can evaluate the results of statistical studies in terms of their own local conditions and with a flexibility of approach that is not available to the courts.").

384. Vanor, supra note 376 , at 765 (footnote omitted).

385. See Coker, 433 U.S. at 592.

386. Id. at 584 .

387. 458 U.S. 782 (1982).

388. Id. at 797-801.

389. Vanor, supra note 376 , at 764. 
appear to violate society's evolving standards. Indeed, when coupled with public opinion polls decidedly against televised executions, ${ }^{390}$ dicta from Justice Brennan's 1972 opinion in Furman v. Georgia ${ }^{391}$ seems particularly compelling: "Today we reject public executions as debasing and brutalizing to us all."392

However, this viewpoint ignores two important considerations. First, legislative enactments cannot always be taken at face value. Legislators have many motives for passing legislation, and an act outlawing televised executions should not necessarily be taken as evidence that society finds such executions "cruel and unusual punishments." Indeed, historical research indicates that private execution statutes were enacted primarily in response to pressure from death penalty abolitionists in the 1830s. ${ }^{393}$ Furthermore, if public executions are truly "cruel and unusual punishments," it seems odd that death row inmates are requesting such executions. After all, why would anyone invite a cruel and unusual punishment?

Thus, especially where death row inmates urge televised executions, such executions cannot be viewed as "cruel and unusual punishments." If this is so, then what is the rationale for private execution statutes? Are they paternalistic regulations intended to protect the general public from viewing such spectacles? Or, even more deviously, are they an attempt to hide the way in which government administers justice?

As a practical matter, private execution statutes were originally enacted for two reasons: (1) paternalism, and (2) fear on the part of death penalty proponents. ${ }^{394}$ Thus, while some legis-

390. See supra note 50. Significantly, the Supreme Court has noted that "any suggestion that the Government's interest in suppressing speech becomes more weighty as popular opposition to that speech grows is foreign to the First Amendment." United States v. Eichman, 496 U.S. 310, 318 (1990).

391. 408 U.S. 238 (1972).

392. Id. at 297; see also Shuman v. State, 578 P.2d 1183, 1188 (Nev. 1978), vacated sub nom. Shuman v. Wolff, 571 F. Supp. 213 (D. Nev. 1983), affd 791 F.2d 788 (9th Cir. 1986), aff'd sub nom. Sumner v. Shuman, 483 U.S. 66 (1987) (Zenoff, C.J., concurring) ("Public televising of executions might serve some deterring value; yet even supporters of the death penalty shudder at the thought of watching an execution.").

393. See supra notes $17-28$ and accompanying text.

394. See supra note 29 (women and non-elites were excluded from attending executions after the enactment of private execution laws). Notably, opponents of capital punishment in the 1830 s may have legitimately believed that the elimination of public executions would lead to the total abolition of the death penalty. See Masur, supra note 10 , at 113 ("Only in the 1840 s did [opponents of capital punishment] begin to 
lators on both sides of the capital punishment debate may want to shield people from watching executions, at least some death penalty proponents undoubtedly believe that televising executions will only increase opposition to the death penalty. ${ }^{395}$ In either case, neither rationale provides a legitimate governmental interest necessary to validate private execution statutes.

Interestingly, if the Supreme Court seriously considers the jurisprudence of Trop and its progeny, granting the public the right to witness executions may be the only way for the Court to properly measure the "evolving standards of decency that mark the progress of a maturing society." To wit: If elected representatives are to be used as the primary "objective indicia" of the evolving standards, all such representatives - and, more importantly, the people who elect those representatives - must have

realize their error. The abolition of public executions not only left capital punishment intact, it also neutralized the argument that the spectacle of execution disordered society."); id. at 117 ("[T]he elimination of public executions had deprived opponents of capital punishment a critical argument: that such spectacles demoralized the population.").

395. One social scientist has argued that "flawed" or "botched" executions could lead to the abolition of the death penalty. See Herb Haines, Flawed Executions, the Anti-Death Penalty Movement, and the Politics of Capital Punishment, 39 Soc. PROBLEMS 125, 127 (1992) ("II]f flawed executions seem to be occurring with some regularity, or if abolitionists are able to turn them into vivid symbols of the death penalty's inherent immorality, they may come to threaten the institution of capital punishment itself."). Historical evidence indicates that public outrage over bungled executions may have led to the abolition of the death penalty in at least two states. Id. (citing evidence from Wisconsin); Black, Botched Execution Did in Death Penalty, MinnEAPOLIS STAR-TRIBUNe, May 12, 1990, at 8A (citing evidence from Minnesota). Furthermore, evidence indicates that a series of botched hangings in New York during the 1880s may have led to the adoption of a more "humane" form of capital punishment: the electric chair. See Haines, supra note 395, at 127. That televised versions of botched executions could have a significant impact on public opinion is reinforced by the frequency of botched executions. See Michael L. Radelet, Post Furman Botched Executions, LIFELINES, No. 50 (1990), at 7 (classifying 12 of approximately 150 post-Furman executions as "botched"); see also Richards \& Easter, supra note 57, at 399-400 (citing evidence of botched executions in Florida and Texas); $c f$. Glass v. Louisiana, 471 U.S. 1080, 1087 (Brennan, J., dissenting) (describing the gruesome nature of electrocution). Obviously, a televised execution of an innocent person could have an even greater impact on public opinion. Cf. Hugo A. Bedau \& Michael L. Radelet, Miscarriages of Justice in Potentially Capital Cases, 40 STANFord L. Rev. 21 (1987) (suggesting that at least 139 innocent people were sentenced to death in the United States between 1900 and 1985 and that 23 of these people were actually put to death); Alabama Death Row Inmate Is Set Free, MinNeAPolis STAR-TribuNE, Mar. 3 , 1993, at 7A (a man condemned to death over four years earlier released because of his innocence). 
full access to information regarding capital punishment. ${ }^{396}$ If not, each time the Supreme Court employs "evolving standards of decency" in the Eighth Amendment context, the Court will be getting an inaccurate measure of such standards. This could result in the Court declaring some punishments acceptable, when society - if fully informed - would find such punishments "cruel and unusual." Under the same principle, some punishments could be declared unconstitutional, when society would approve of such punishments if adequately informed.

Two death penalty cases, Furman v. Georgia ${ }^{397}$ and Gregg v. Georgia, ${ }^{398}$ demonstrate this hypothesis at work. In 1972 in Furman, the United States Supreme Court struck down state death penalty statutes fraught with unbridled jury discretion. ${ }^{399}$ Writing for the majority, Justice Brennan concluded that the death penalty's "rejection by contemporary society is virtually total." "400 In reaching this conclusion, Justice Brennan focused on the history of "successive restriction[s]" on capital punishment and the "increasingly rare" application of the penalty ${ }^{401}$ However, the public's "backlash" to Furman was severe, with thirty-five states reenacting death penalty legislation in "a virtual stampede." 402

Thus, when the Court in Gregg upheld a death sentence four years later, Justices Powell, Stevens, and Stewart readily conceded that the state reenactments had "undercut" Furman's premise: "It is now evident that a large proportion of American society continues to regard [capital punishment] as an appropriate and necessary criminal sanction." ${ }^{\text {403 }}$ Despite this concession, however, Justice Marshall insisted that "the American people, [if] fully informed as to the purposes of the death penalty and its liabilities, would in my view reject it as morally unaccept-

396. This is especially true in states like California, where citizens have the opportunity to vote on referendums with respect to capital punishment. See Plaintiff's Trial Brief at 16 n.18, KQED, Inc. v. Vasquez, 18 Media L. Rptr. 2323 (N.D. Cal. 1991) (No. C90-1383RHS).

397. 408 U.S. 238 (1972).

398. 428 U.S. 153 (1976).

399. Furman, 408 U.S. at 238.

400. Id. at 305 .

401. Id. at 299.

402. John H. Ely, Democracy AND Distrust 65 (1980).

403. Gregg, 428 U.S. at 179. 
able." ${ }^{\prime 204}$ In particular, Marshall stressed that the constitutionality of capital punishment turns "on the opinion of an informed citizenry," and that, therefore, "even the enactment of new death statutes cannot be viewed as conclusive." 405

In his book, Death Penalties, Raoul Berger criticizes Justice Marshall's approach. Rejecting the notion that "statutes must yield to Marshall's speculations as to what the people would do if informed of data Marshall deems decisive," Berger relies on the philosopher Sidney Hook to support his position. ${ }^{406}$ According to Hook, "It is arrogant [to assume that] some self-selected

404. Id. at 232 (Marshall, J., dissenting). Justice Marshall continued:

In Furman, I observed that the American people are largely unaware of the information critical to a judgment on the morality of the death penalty, and concluded that if they were better informed they would consider it shocking, unjust, and unacceptable. ... A recent study, conducted after the enactment of the post-Furman statutes, has confirmed that the American people know little about the death penalty, and that the opinions of an informed public would differ significantly from those of a public unaware of the consequences and effects of the death penalty.

Gregg, 428 U.S. at 232 (Marshall, J., dissenting) (citing Furman, 408 U.S. at 360-69 and Austin Sarat \& Neil Vidmar, Public Opinion, the Death Penalty, and the Eighth Amendment: Testing the Marshall Hypothesis, 1976 WIS. L. REV. 171).

405. Gregg, 428 U.S. at 232 (Marshall, J., dissenting) (emphasis in original). Social science studies have shown that the general public lacks knowledge about the death penalty and that information about capital punishment often changes attitudes with respect to the death penalty. See generally Robert M. Bohm, American Death Penalty Opinion, 1936-1986: A Critical Examination of the Gallup Polls, in The DEATH PENALTY IN AMERICA: CURRENT RESEARCH 130-37 (Robert M. Bohm ed., 1991); Robert M. Bohm et al., Knowledge and Death Penalty Opinion: $A$ Test of the Marshall Hypotheses, 28 J. RES. CRIME \& DeLINQ. 360 (1991); Robert M. Bohm, The Effects of Classroom Instruction and Discussion on Death Penalty Opinions: A Teaching Note, 17 J. CRIM. JusT. 123 (1989); James O. Finckenauer, Public Support for the Death Penalty: Retribution as Just Deserts or Retribution as Revenge?, 5 JUST. Q. 81 (1988); Phoebe C. Ellsworth \& Lee Ross, Public Opinion and Capital Punishment: $A$ Close Examination of the Views of Abolitionists and Retentionists, 29 CRIME \& DELINQ. 116 (1983); Sarat \& Vidmar, supra note 404, at 171; Neil Vidmar \& Tony Dittenhoffer, Informed Public Opinion and Death Penalty Attitudes, 23 Canadian J. CRIMINolOGY 43 (1981); Robert M. Bohm, Death Penalty Opinions: A Classroom Experience and Public Commitment, 60 Soc. INQUIRY 285 (1990). But see Charles G. Lord et al., Biased Assimilation and Attitude Polarization: The Effects of Prior Theories on Subsequently Considered Evidence, 37 J. Personality \& Soc. Psychology 2098 (1979) (concluding that information or knowledge about the death penalty polarized opinions, instead of changing them from in favor to opposed or vice versa). For a social science study exploring the relationship between public opinion and retribution in the context of the death penalty, see Robert M. Bohm, Retribution and Capital Punishment: Toward a Better Understanding of Death Penalty Opinion, 20 J. CRIM. JusT. 227 (1992).

406. Raoul Berger, Death Penalties 126 (1982). 
elite can better determine what the best interests of other citizens are than those citizens themselves."407 However, in the context of private execution laws, Berger's criticism of Justice Marshall can be turned on its head. For, by continuing to deprive the public of vital information regarding capital punishment, private execution statutes embody the paternalism that Hook so vehemently rejects. Ironically, unless televised executions are allowed, the public may be denied access to the very information which Justice Marshall deems so decisive.

In today's society, the influence of television cannot be underestimated. Roper surveys since 1964 list television as America's number one news source, ${ }^{408}$ and "it cannot be denied that television news coverage plays an increasingly prominent part in informing the public at large of the workings of government." 409 Indeed, speaking in the trial context, Justice Harlan once mused that "televising [trials] might well provide the most accurate and comprehensive means of conveying their content to the public."410 A growing number of cable television stations

407. Sidney Hook, Philosophy and Public Policy 29 (1980).

408. See Charles E. Ares, Chandler v. Florida: Television, Criminal Trials and Due Process, 1981 SUP. CT. REv. 157, 174 n.74 (1982) (citing RoPER ORGANIZATION, Public Perception of Television and OTHer Mass Media: A TWENTY Year REVIEW, 1959-1979)). The average adult in the United States spends more than thirty hours each week watching television. A.C. NiELSEN Co., NIELSEN REPORT ON TELEvision 8 (1990). Furthermore, 69\% of such adults acquire most of their news from television. Rod Granger, Cable Viewers Want Big 3, Study Finds, ELECTRONIC Media, May 6, 1991, at 8 (citing Roper Organization, "America's Watching: Public Attitudes Towards Television"). While the combined circulation of the three major news magazines-Time, Newsweek, and U.S. News and World Report-is just over ten million, television news reaches over 200,000,000 viewers in the United States. See Oxbridge Communications, Inc., The Standard Periodical DiRECTORY 1127-28 (13th ed. 1990); VANDERBILT TELEVISION NEwS ARChIVE, TelEVISION NEWS INDEX AND ABSTRACTS (Jan. 1976 - Dec. 1987). Only two percent of the population gets its news from sources exclusive of television. TIO/Roper Report, "America's Watching: 30th Anniversary, 1959-1989, at 27. Televising executions is of added importance because thirteen percent of U.S. citizens are either illiterate or functionally illiterate. Richard Weizel, From New Words, New Worlds, N.Y. TIMES, May 3, 1992, $\S 13 \mathrm{CN}$, at 1 (citing United States Department of Education statistics). Moreover, Americans regard television as the most complete and unbiased source of news. The Roper Organization, Trends in AtTitudes Towards Television AND OTHER MEDIA: A TWENTY-FOUR YEAR REVIEW 4 (1983).

409. Cable News Network v. American Broadcasting Co., 518 F. Supp. 1238, 1245 (N.D. Ga. 1981) (electronic media have a right to be included in the press pool for "limited coverage" of White House events); see also FCC v. Pacifica Found., 438 U.S. 726, 748 (1978) (broadcasting's "uniquely pervasive presence").

410. Estes v. Texas, 381 U.S. 531, 589 (1965) (Harlan, J., concurring). 
such as CNN and C-SPAN-providing live, extended coverage-promise to make television an even more potent medium for news dissemination.

Given television's tremendous impact on society, televising executions will undoubtedly influence the capital punishment debate. Some proponents of capital punishment may switch sides after viewing an execution, and some death penalty opponents may be persuaded, after watching an execution, that capital punishment is not so bad after all. 411 Whatever the impact of televised executions, though, society's attitudes regarding capital punishment will change. ${ }^{412}$ Additionally, the infusion of information into the death penalty debate may alter society's views on related matters. For example, society may develop a consensus regarding the most humane form of capital punishment (i.e., hanging, firing squad, electrocution, lethal gas or lethal injection). ${ }^{413}$

411. A recent public opinion poll asked whether viewing an execution on television would make people more in favor of the death penalty, less in favor, or wouldn't it change their mind. While $14 \%$ of respondents felt that viewing an execution would make them more in favor of the death penalty, $36 \%$ felt that it would make them more opposed to capital punishment. Forty percent believed that a televised executions wouldn't change their minds, while $10 \%$ weren't sure. See Roper Center for Public Opinion Research, University of Connecticut (1991) (WESTLAW, POLL database). For more than two decades, public opinion surveys consistently have found that two-thirds of the population favors capital punishment. FRANKLIN E. Zimring \& Gordon Hawkins, Capital Punishment and The American AGENDA 15 (1986).

412. Cf. Sarat \& Vidmar, supra note 404, at 195 (a study concluding that exposure to information about the death penalty changed the subjects' attitudes). Anita Hill's Congressional testimony and the Rodney King video amply demonstrate the impact of television coverage with respect to public discourse on issues like harassment in the workplace and police brutality.

413. See Martin R. Gardner, Executions and Indignities-An Eighth Amendment Assessment of Methods of Inflicting Capital Punishment, 39 OHIO ST. L.J. 96 (1978); Angeja, supra note 124, at 1514-16 (arguing that televised executions may develop societal consensus regarding the most humane form of capital punishment); see also Glass v. Louisiana, 471 U.S. 1080, 1086-88 (1985) (Brennan, J., dissenting) (Justices Brennan and Marshall dissented from a denial of certiorari where the defendant had claimed that use of the electric chair constituted cruel and unusual punishment under the eighth amendment); Gray v. Lucas, 463 U.S. 1237, 1241 (1983) (Marshall, J., dissenting) (Justices Marshall and Brennan dissented from a denial of certiorari where the defendant had claimed that use of the gas chamber constituted cruel and unusual punishment under the eighth amendment).

That more information about the method of inflicting capital punishment may change attitudes about the most humane form of punishment is supported by an execution that took place in Arizona just prior to Robert Alton Harris' execution in 
Because jury determinations are also an "objective indicia" of "evolving standards of decency,"414 a jury should be allowed to view an execution film at the defendant's request. This would assure that jury determinations at the sentencing phase do

California. The gas chamber execution in Arizona, which took place on April 6, 1992, was described by witnesses to the execution, including media representatives, as a horrible occurrence. See Gruesome Death in Gas Chamber Pushes Arizona Toward Injections, N.Y. TIMEs, Apr. 25, 1992, at 9. Immediately after the execution, the Arizona Attorney General called for the abandonment of that mode of execution and efforts were made in the state legislature to amend the law. See Reinhardt, supra note 132, at 219; Calabresi \& Lawson, supra note 132, at 267. But compare id. at 269-70 ("Nor does the subsequent opinion of the Arizona Attorney General, who is merely one government official, demonstrate the necessary consensus within Arizona that the gas chamber is an inappropriate mode of execution. . . . The pendency in the Arizona legislature of a bill to change that state's mode of execution also does not make Harris' claim [of 'cruel and unusual punishment'] more plausible, because the law authorizing use of the gas chamber in Arizona remains on the books.") with id. at 270 n.70 (noting that a recent amendment in California gives capital defendants a choice between the gas chamber and lethal injection).

Significantly, the increased debate that televised executions would spur might also affect the public's views with respect to (1) the monetary costs of administering the death penalty, (2) the appropriateness of capital punishment for juveniles, and (3) the appropriateness of capital punishment for the mentally or physically impaired. See Dorothy O. Lewis et al., Psychiatric, Neurological, and Psychoeducational Characteristics of 15 Death Row Inmates in the United States, 143 AM. J. PsYCHIATRY 838 (1986) (a study of 15 death row inmates finding that all 15 "had histories of severe head injury, five had major neurological impairment, and seven others had other, less serious neurological problems"). Aside from the myriad issues surrounding the death penalty that televised executions would also stimulate debate about, increased news coverage associated with televised executions might also publicize the racial bias in capital sentencing decisions. See David C. Baldus ET Al., EQUAL JuSTICE AND the Death Penalty (1990); Samuel R. Gross \& Robert Mauro, Death and Discrimination: Racial DisParities in CAPITAL SENTENCING (1989).

414. As the Supreme Court has previously observed, "the jury . . . is a significant and reliable objective index of contemporary values because it is so directly involved." Gregg v. Georgia, 428 U.S. 153, 181; see also Witherspoon v. Illinois, 391 U.S. 510, 519 n.15 (1968) (Warren, C.J., plurality opinion):

[O]ne of the most important functions any jury can perform . . . is to maintain a link between contemporary community values and the penal systema link without which the determination of punishment could hardly reflect "the evolving standards of decency that mark the progress of a maturing society."

To the extent that prospective jurors opposed to the death penalty can be excluded from jury panels, the Supreme Court's decisions in Witherspoon and Wainwright v. Witt, 469 U.S. 412 (1985) are inconsistent with the eighth amendment principle that punishments must not violate the "evolving standards of decency" because the jury panel does not fully reflect community values. $C f$. Morgan v. Illinois, $112 \mathrm{~S}$. Ct. 2222 (1992) (a defendant in a capital case has a constitutional right to remove potential jurors who would automatically vote for execution in the event of conviction). 
"mark the progress of a maturing society." Indeed, it is hard to imagine information more relevant to a capital sentencing decision than an execution film. For, along with balancing the aggravating and mitigating circumstances of a crime at the sentencing phase, juries must also fashion the punishment to fit the crime. In this respect, not only is viewing an execution film relevant to a jury's sentencing decision, but the unconstitutionality of disproportionate punishments demands that a jury be allowed to view such a film. After all, how can a jury assess the appropriateness of capital punishment without knowing how the death penalty is administered and how such a sentence affects both physically and psychologically - a person on death row or in the execution chamber?

Additionally, allowing juries to view execution films is fully consistent with Supreme Court precedent. Beginning with Lockett v. Ohio ${ }^{415}$ in 1978 , the Court has consistently held that the Eighth Amendment requires that the sentencer not be precluded from considering any mitigating evidence in deciding whether to impose the death penalty. ${ }^{416}$ Although Lockett dealt with evidence regarding the defendant's character and the circumstances of the offense, given the "qualitative difference" between the death penalty and other punishments, ${ }^{417}$ defendants should be allowed to present execution film footage as mitigating evidence

415. 438 U.S. 586 (1978).

416. According to the precise language of the Lockett plurality, "the Eighth and Fourteenth Amendments require that the sentencer, in all but the rarest kind of capital case, not be precluded from considering, as a mitigating factor, any aspect of a defendant's character or record and any of the circumstances of the offense that the defendant proffers as a basis for a sentence less than death." Lockett, 438 U.S. at 604 (emphasis in original) (footnotes omitted); see also Eddings v. Oklahoma, 455 U.S. 104, 114-15 (1982) (A majority of the Court held that "[t]he sentencer, and the [state appellate court] on review, may determine the weight to be given relevant mitigating evidence. But they may not give it no weight by excluding such evidence from their consideration."); Walton v. Arizona, 497 U.S. 639, 679 n.2 (1980) (Blackmun, J., dissenting) ("Eight members of the Court agree that Lockett remains good law . . . .").

417. See, e.g., California v. Ramos, 463 U.S. 992, 998-99 (1983) ("[T] he qualitative difference of death from all other punishments requires a correspondingly greater degree of scrutiny of the capital sentencing determination."); Lockett, 438 U.S. at 604 (plurality opinion) (The "qualitative difference between death and other penalties calls for a greater degree of reliability when the death sentence is imposed."); Woodson v. North Carolina, 428 U.S. 280, 305 (plurality opinion) (because of that qualitative difference, there is a corresponding difference in the need for reliability in the determination that death is the appropriate punishment in a specific case); Lockett, 438 U.S. at 605 ("Given that the imposition of death by public authority is so profoundly different 
during the sentencing phase. ${ }^{418}$ Indeed, dissenting in Thompson v. Oklahoma, ${ }^{419}$ Chief Justice Rehnquist and Justices Scalia and White suggested in dicta that no constitutional violation occurred where color photographs of a victim were introduced at the sentencing phase of a capital murder case. ${ }^{420}$ If color photographs of a victim - such as the ones in Thompson "showing gunshot wounds in the head and chest, and knife slashes in the throat, chest and abdomen" — are "probative" and not "unduly inflammatory," 421 then an execution film can hardly be considered irrelevant to a jury's sentencing decision.

As to Trop's admonition that a punishment not offend the "dignity of man," filming an execution, even over the death row

from all other penalties, we cannot avoid the conclusion that an individualized decision is essential in capital cases.").

418. Prosecutors opposed to the introduction of such evidence are likely to argue that execution footage is only intended to create sympathy for the accused. However, mercy is often considered an appropriate element for the jury to consider when deciding whether to impose a death sentence. See Bruce I. McDaniel, Annotation, Instructions to Jury: Sympathy to Accused as Appropriate Factor in Jury Consideration, 72 A.L.R.3d 842 (citing cases). As one commentator has stated:

[C]hoosing whether another is to live or die is a disturbing and daunting moral challenge. This decision should not be made purely by following rules or by weighing aggravating and mitigating circumstances. Rational decision procedures imply that no one has really made a choice, and that implication is one which is not acceptable in a supposedly moral society. Empathy and emotion are properly injected into decisions about capital punishment.

Paul W. Cobb, Jr., Note, Reviving Mercy in the Structure of Capital Punishment, 99 YALE L.J. 389, 409 (1989) (footnote omitted). Compare California v. Brown, 479 U.S. 538 (1987) (an instruction requiring jurors to ignore "mere sentiment, conjecture, sympathy, passion, prejudice, public opinion or public feeling" was not unconstitutional) with Saffle v. Parks, 494 U.S. 484, 509-10 (1990) (Brennan, J., dissenting) (an instruction requiring jurors to "avoid any infuence of sympathy, sentiment, passion, prejudice or other arbitrary factor" should be declared unconstitutional because it forbids the jury from taking into account any evidence that evoked a sympathetic response) and id. at 513 (Brennan, J., dissenting) ("sympathy" is "an important ingredient in the Eighth Amendment's requirement of an individualized sentencing determination) and Cisarik v. Palos Community Hosp. 579 N.E.2d 873 (Ill. 1991) (permitting use of day-in-the-life video in medical malpractice action).

419. 487 U.S. 815 (1988). The Supreme Court in Thompson held that the imposition of the death penalty on a 15-year-old boy violated the cruel and unusual punishment clause of the Eighth Amendment.

420. Id. at 878 (Scalia, J., dissenting). Because of the Court's disposition of the eighth amendment issue, the Court in Thompson did not address the issue of whether photographic evidence that a state court deems erroneously admitted but harmless at the guilt phase nevertheless violates a capital defendant's constitutional rights by virtue of being admitted at the penalty phase. Id. at $838 \mathrm{n} .48$.

421. Id. at 878 (Scalia, J., dissenting). 
inmate's objection, would not violate this principle. First, televised executions would arguably make a measurable contribution to the accepted goals of punishment. In this regard, the words of Chief Justice Burger in Richmond Newspapers are particularly significant: "When a shocking crime occurs, a community reaction of outrage and public protest often follows. Thereafter the open processes of justice serve an important prophylactic purpose, providing an outlet for community concern, hostility, and emotion."422 Finding the "keystone" of open criminal trials to be "the therapeutic value of open justice," Chief Justice Burger stated as follows:

Civilized societies withdraw both from the victim and the vigilante the enforcement of criminal laws, but they cannot erase from people's consciousness the fundamental, natural yearning to see justice done - or even the urge for retribution. The crucial prophylactic aspects of the administration of justice cannot function in the dark; no community catharsis can occur if justice is "done in a corner [or] in any covert manner." 424

According to Chief Justice Burger, "[T]he appearance of justice can best be provided by allowing people to observe it. ... People in an open society do not demand infallibility from their institutions, but it is difficult for them to accept what they are prohibited from observing." 425 Thus, not only are televised executions consistent with retributive theory, ${ }^{426}$ but such events would ar-

422. Richmond Newspapers, Inc. v. Virginia, 448 U.S. 555, 571 (1980) (citation omitted).

423. Id. at 569 .

424. Id. at 571 (quoting 1677 Concessions and Agreements of West New Jersey, reprinted in SOURCES OF OUR LIBERTIES 188 (R. Perry ed., 1959)).

425. Id. at 572. In Press-Enterprise v. Superior Court, 464 U.S. 501 (1984), where the Court held that access to voir dire proceedings outweighed the state's interest in protecting the privacy of prospective jurors in a capital case, Chief Justice Burger reiterated the "community therapeutic value" in openness. According to Burger: "When the public is aware that the law is being enforced and the criminal justice system is functioning, an outlet is provided for these understandable reactions and emotions" like "retribution." Id. at 508-09.

426. See generally Bruce Beddow, Retributive Theory and Public Executions 8 (Nov. 30, 1990) (unpublished manuscript) ("[T]here is no better way to feel that justice is being done, than to see it being done." (emphasis in original)). Notably, some commentators argue that retributive theory does not require capital punishment, with some suggesting that the death penalty is immoral under retributive principles. See JEFFRIE G. MURPHY, RETRIBUTION, JUSTICE, AND THERAPY 223-49 (1979); HERBERT MoRris, ON GUILt AND InNOCEnCE (1976); Robert A. Pugsley, A Retributivist Argument Against Capital Punishment, 9 HofsTRA L. REV. 1501 (1981); M. 
guably further the principle of deterrence. ${ }^{427}$ Finally, televised executions are not disproportionate to the crimes that death row inmates commit, especially considering the heinous nature of many of those crimes.

\section{CONCLUSION}

In the past, constitutional challenges to private execution statutes have focused primarily on the right of the press to attend executions. In Garrett v. Estelle ${ }^{428}$ and Kearns-Tribune v. Utah Board of Corrections, ${ }^{429}$ for example, broadcast journalists challenged restrictions on the filming of executions on Equal Protection grounds. Additionally, challenges have been brought alleging unlawful prior restraint and a constitutional right of access for the press to attend executions.

However, these constitutional challenges have failed for several reasons. First, each of these challenges have been unable to overcome the principle that the government does not have to give the press special access to information not shared by the public generally. ${ }^{430}$ Second, litigants challenging private execution statutes have tried to use long-standing legal doctrines in novel and perhaps undesirable ways. For instance, it was argued in Garrett that the proposed closed circuit television broadcast of an execution was a "publication" invoking the prior restraint doctrine. However, the prior restraint doctrine was intended primarily to prohibit government censorship of information already in the hands of private parties, ${ }^{431}$ and the journalists watching the closed circuit broadcast in Garrett never had a videotape of the execution in their possession. Likewise, in both Garrett and Kearns-Tribune, the plaintiffs brought Equal Protection challenges on the ground that broadcast journalists are fundamentally different than print journalists. Although a television broadcast is often a more potent medium than a newspaper story, some private execution statutes do not expressly

Margaret Falls, Retribution, Reciprocity, and Respect for Persons, 6 LAW \& PHIL. 25 (1987); ANDREW VON HIRSCH, PAST OR FutuRE CRIMES 26 n.4 (1987).

427. See supra note 1.

428. 556 F.2d 1274 (5th Cir. 1977).

429. 2 Media L. Rep. (BNA) 1353 (D. Utah 1977).

430. See Pell v. Procunier, 417 U.S. 817 (1974); Saxbe v. Washington Post Co., 417 U.S. 843 (1974).

431. See stupra Section VII(A). 
provide for the attendance of media representatives. , Furthermore, states have, to date, successfully countered Equal Protection attacks by throwing up "sham" justifications for private execution laws, with one state even attempting to exclude all journalists from executions in an attempt to moot an Equal Protection challenge. ${ }^{432}$

To challenge private execution laws more effectively, litigants must question the premise of their attack. Instead of asking if the press has a right to televise executions, litigants must ask whether the public has a right to witness executions. Indeed, because states may attempt to stifle press challenges altogether by allowing no witnesses at all at execution proceedings, ${ }^{433}$ asking if the public has a right to witness executions may be the only way to preserve the press' right to attend and televise such events.

Given the shortcomings of broadcasters' prior restraint and Equal Protection challenges, litigants must assert that the public has a constitutional right to view executions. This right should be rooted in history and should focus on the lack of governmental interests supporting private execution statutes. Similarly, private execution laws should be challenged as impermissible restrictions on the content of speech. ${ }^{434}$ Indeed, because the propriety of capital punishment is a political issue ${ }^{435}$-and because private execution laws were originally enacted, and are still

432. See supra Section IV.

433. Recently, in KQED's lawsuit challenging San Quentin's private execution regulations, the warden of San Quentin, Daniel Vasquez, tried this tactic. Williams, supra note 107, at A23. In that attempt, Vasquez told a reporter that he changed the long-standing policy with Gov. Wilson's approval so that Judge Schnacke could not rule that since reporters are allowed to attend executions they should be allowed to use the tools of their trade. Rosenfeld, Warden Afraid of Revenge on Guards if Executions on $T V$, SAN FraNCISCo ExAMINER, at A.5. However, in his ruling, Judge Schnacke decided that all reporters could not be excluded from witnessing executions. KQED Inc. v. Vasquez, 18 Media L. Rep. (BNA) 2323, 2324 (N.D. Cal. 1991).

434. In particular, it could be argued that the media should be given "effective" access to executions under Justice Stewart's concurring opinion in Houchins. See Houchins v. KQED, Inc., 438 U.S. 1, 16 (Stewart, J., concurring).

435. Capital punishment has become a critical issue in many elections throughout the United States. See Tao, supra note 80, at 1042 n.4 (citing articles). For example, in a Gallup poll taken after the 1988 election, the death penalty was given as a very important issue in deciding for whom to vote for fifty-seven percent of Bush voters and thirty-eight percent of Dukakis voters. George Gallup, Jr. \& Alec Gallup, "Public Support for Death Penalty is Highest in Gallup Annals" (1988). 
maintained, for paternalistic reasons or to impede the debate surrounding capital punishment-private execution laws should be strictly scrutinized under the First Amendment. Ultimately, decisions about whether to broadcast executions should be left in the hands of journalists, just as the general public must decide whether to watch executions. The government should not be given the right to decide what is appropriate television viewing or what is appropriate for journalists and editors to broadcast.

In assessing the constitutionality of private execution statutes, the history of public executions cannot be emphasized enough. For, as illustrated in the death penalty and the right of access to trial cases, members of the Supreme Court often employ historical analyses in reaching their decisions. And, while the framers of the Constitution and the Bill of Rights, by definition, could have had no intent regarding televised executions, this fact does not render history irrelevant. ${ }^{436}$ On the contrary, for the ardent originalist, the one fact that would be relevant is that the framers approved of large crowds of people watching executions. Although this fact may not carry much weight for the nonoriginalist, it does not inhibit the Supreme Court from finding a constitutional right of access to executions. ${ }^{437}$

436. The fact that televised trials are not permitted in some federal and state courts does not preclude the finding of a public right to witness televised executions. Simply stated, the reasons given for excluding cameras in the courtroom-disruption of the proceedings and the potential effect of cameras on jurors, witnesses and judges-do not apply in the execution context. Furthermore, 44 states currently allow video cameras in the courtroom for various reasons, and the federal courts' policy regarding cameras in the courtroom is being revised, with the Judicial Conference having already authorized some experimentation. See Ronald K.L. Collins \& David M. Skover, Paratexts, 44 STAN. L. REv. 509, 512 \& n. 14 (1992); see also id. at 510 ("We live in an era of 'paratexts,' in which words and images, as captured by electronic recording, compete with print to represent legally significant events.").

437. In Richmond Newspapers, Justice Brennan stated in his concurring opinion that "the case for a right of access has special force when drawn from an enduring and vital tradition of public entree to particular proceedings or information." Richmond Newspapers, Inc. v. Virginia, 448 U.S. 555, 589 (1980) (Brennan, J., concurring) (citation omitted). Because the United States, until the nineteenth and early twentieth centuries, had a long tradition of unrestricted public access to executions, the notion that the public has a right to view executions is particularly strong. Indeed, the public's right to receive information has been frequently recognized by the Supreme Court. See, e.g., Metro Broadcasting, Inc. v. FCC, 497 U.S. 367-68 (1990); Virginia Pharmacy Bd. v. Virginia Consumer Council, 425 U.S. 748, 756 (1976); Kleindienst v. Mandel, 408 U.S. 753, 762-65 (1972); Lamont v. Postmaster General, 381 U.S. 301, 308 (1965). 
Regardless of judicial philosophy, however, an historical approach based upon more than the framers' intent, provides a compelling argument for finding private execution statutes unconstitutional when coupled with the jurisprudence of the First Amendment and Trop v. Dulles. ${ }^{438}$ Truly ascertaining the "evolving standards of decency that mark the progress of a maturing society" only can be realized through robust debate. Furthermore, the government cannot be allowed to stop the natural evolution of debate on a public issue by privatizing conduct, especially on an issue as important as the death penalty. ${ }^{439}$

According to historians, a primary reason that executions were privatized was a powerful movement to abolish capital punishment in the $1830 \mathrm{~s} .{ }^{440}$ If this is so, by reducing the availability of information to the public regarding capital punishment, state governments engaged in a "cover-up" beginning in the nineteenth century. Although the continuation of public executions may not have resulted in the abolition of the death penalty, it is reasonable to assume that the public's perception of the death penalty would be different today if the United States had continued the practice of public executions. In order for society to continue its evolution on the capital punishment issue-either pro or con-it is imperative that broadcast journalists, acting as representatives of the people, be allowed to televise executions.

438. 356 U.S. 86 (1958).

439. Currently, there are over 2,500 inmates on Death Row. Mark Hansen, Final Justice: Limiting Death Row Appeals, A.B.A. J., Mar. 1992, at 64. Furthermore, the debate surrounding capital punishment will become even more significant if Congress expands the use of the death penalty through federal crime bills. See H.R. 3371, 102d Cong. 2d Sess. (1992); 138 CoNG. REc. S3939 (daily ed. Mar. 19, 1992) (statement of Sen. Biden) ("This bill adds 53 death penalty offenses-the single largest expansion of the Federal death penalty in the history of the Congress.").

440. Mamantov, supra note 9, at 375; see also MACKEY, supra note 18, at 115-19 (1982) (containing a discussion of how abolitionists opposed private execution statutes in New York). 